\title{
Accounting Standards Harmonization and Financial Integration*
}

\author{
Dan Dhaliwal \\ Department of Accounting \\ University of Arizona \\ (deceased) \\ Wen He \\ UQ Business School \\ The University of Queensland \\ wen.he@uq.edu.au \\ Yan $\mathrm{Li}^{\dagger}$ \\ Department of Accounting \\ University of Melbourne \\ yan.li@unimelb.edu.au \\ Raynolde Pereira \\ School of Accountancy \\ University of Missouri \\ pereirar@missouri.edu
}

October 2018

\begin{abstract}
* Accepted by Michael Welker. We are grateful to the valuable comments and suggestions from two anonymous referees, Michael Welker (the editor and the Editor-in-Chief), Jeff Pittman (the deputy Editor-in-Chief), Margaret Abernethy, Jeffrey Callen, Mark DeFond, Bin Ke, Charles Lee, Matthew Pinnuck, Shiva Rajgopal, Eddie Riedl (discussant), Jianfeng Shen, Siew Hong Teoh, Joanna Wu (discussant), and Bohui Zhang. This paper has also benefited from the comments of the discussants and workshop participants at the FARS 2013 conference, the EAA 2013 annual congress, the CAAA 2013 annual meeting, the AAA 2013 annual meeting, MIT-Asia 2014 conference, University of Queensland, University of Melbourne, University of Western Australia, and Xiamen University. Yan Li acknowledges the financial support from Singapore MOE Tier 1 academic research fund.

† Corresponding author: yan.li@unimelb.edu.au

This is the author manuscript accepted for publication and has undergone full peer review but has not been through the copyediting, typesetting, pagination and proofreading process, which may lead to differences between this version and the Version of Record. Please cite this article as doi: $10.1111 / 1911-3846.12495$
\end{abstract}

This article is protected by copyright. All rights reserved. 


\title{
Accounting Standards Harmonization and Financial Integration
}

\begin{abstract}
We empirically examine whether adopting a uniform set of accounting standards mitigates information frictions in financial markets and facilitates market integration. Using a difference-indifference design, we find that after the mandatory adoption of International Financial Reporting Standards (IFRS), local stock returns incorporate more global information and at a faster speed. The effect of IFRS adoption is stronger in countries where there are larger improvements in accounting comparability and for firms with a larger increase in foreign ownership. Overall, our results suggest that accounting standards harmonization facilitates financial market integration.
\end{abstract}




\section{Introduction}

Over the past few decades, financial markets around the world have become increasingly integrated due to the gradual removal of capital controls and efforts to promote market integration. However, significant financial market segmentation still exists (Giannetti et al. 2002; Bekaert et al. 2011). One reason for incomplete market integration is information frictions that prevent investors from collecting, processing, and using value relevant information in a timely manner (Bekaert 1995; Bekaert et al. 2003). In particular, accounting standards differ from country to country, making it difficult for global investors to compare and interpret accounting numbers across countries (Covrig et al. 2007). In 2005, a number of countries around the world adopted International Financial Reporting Standards (IFRS) to provide global investors with comparable financial information by using a uniform set of accounting standards. In this study, we use mandatory adoption of IFRS to investigate whether accounting standards harmonization facilitates financial market integration.

Based on the law of one price, researchers in international finance conclude that in fully integrated markets securities are priced based on their exposure to non-diversifiable global risk factors (Stulz 1981; Errunza and Losq 1985). For example, Bekaert and Harvey $(1995,403)$ state that "markets are completely integrated if assets with the same risk have identical expected returns irrespective of the market.” Pukthuanthong and Roll (2009) propose that markets could be globally integrated as long as the same global risk factors determined the prices of all the stocks in all countries. ${ }^{1}$ The attention on financial integration is due to the range of benefits identified by the literature including a lower cost of capital (Errunza and Losq 1985; Henry 2000a), more corporate investments (Henry 2000b), and higher economic growth (Bekaert and Harvey 2001). In light of these

\footnotetext{
${ }^{1}$ Specifically, Pukthuanthong and Roll $(2009,215)$ state that "We contend that markets could be globally integrated even if assets were irrationally priced so long as the same global shocks permeate all countries. We do not mean to say that all or any shocks are irrational, but if some are, markets would still be integrated if the same irrationalities propagate globally." This statement implies that irrational shocks could be contagious or spread across integrated markets, but Karolyi (2003) surveys the literature and concludes that there is no clear evidence of the existence of financial market contagion.
} 
positive effects, many countries implemented various policies to achieve financial and economic integration, including opening domestic markets to foreign investors, removing foreign exchange controls, and promoting international trade and investment through free trade agreements.

The literature on IFRS adoption has provided some evidence that foreign investment increased following mandatory IFRS adoption. ${ }^{2}$ For example, some studies find IFRS adoption leads to an increase in equity ownership by foreign investors (DeFond et al. 2011; Florou and Pope 2012; Yu and Wahid 2014), more cross-border mergers and acquisitions (Francis et al. 2012; Louis and Urcan 2014), and more foreign direct investments (Gordon et al. 2012). While increases in foreign investment imply economic integration, these studies do not provide direct evidence on whether financial integration improved and stock prices became more driven by global risk factors following IFRS adoption. In fact, international finance literature suggests that economic integration is not necessarily linked to financial integration. For example, Bekaert and Harvey (1995) point out that market integration is a complex process and markets could remain segmented even though foreigners may have relatively easy access to local capital markets. Bekaert et al. (2013) show the adoption of the Euro as a single currency in Europe, which should have removed exchange rate risks and improved economic integration, did not lead to improved market integration in European countries. ${ }^{3}$

Furthermore, the effect of IFRS adoption on foreign investment appears to be small in magnitude. DeFond et al. (2011) estimate that mandatory IFRS adoption results in a mere $0.8 \%$ increase in foreign mutual fund ownership, leaving it unclear whether such a small increase in foreign ownership can effectively improve financial integration. Therefore, it remains an open empirical question whether the accounting harmonization achieved through mandatory IFRS adoption leads to more integrated financial markets. Given the economic benefits of financial market integration

\footnotetext{
${ }^{2}$ Please refer to De George et al. (2016) for a recent review of IFRS literature.

${ }^{3}$ A different view is expressed by Kalemli-Ozcan et al. (2008) who show that the adoption of the Euro has a positive impact on cross-border banking activities and consumption risk sharing.
} 
documented in the literature, we believe that it is important to document direct evidence of the effect of IFRS adoption induced accounting harmonization on financial market integration.

To assess the impact of IFRS adoption on financial integration, we focus on two firm-level measures of financial integration based on the extent to which equity prices are driven by global risk factors. ${ }^{4}$ The first measure is the proportion of stock return variations that can be explained by global market returns, with a larger proportion indicating a higher degree of integration. This measure follows Pukthuanthong and Roll $(2009,214)$ who propose that "a sensible intuitive quantitative measure of financial market integration is the proportion of a country's returns that can be explained by global factors.” The measure has the advantage of being consistent with the theory of financial integration ${ }^{5}$ but does not rely on any specific international asset pricing model. The second measure captures the speed at which global information is incorporated into stock prices, with faster speed indicating more integrated markets. The rationale for this measure is that in fully integrated markets, shocks to global risk factors should quickly transmit across markets without delay so that integrated markets are also efficient markets. Consistent with this view, Bae et al. (2012) find that global information is incorporated into local stock prices in a more timely manner in the markets that are more accessible to foreign investors.

Following the literature, we use a difference-in-difference approach to isolate the effects of mandatory IFRS adoption while accounting for other factors that may contribute to financial integration. We use the year 2005 as a cut-off year to compare pre- and post-IFRS adoption regimes. Our sample consists of firm-level observations from 34 countries: 17 countries imposed mandatory adoption of IFRS in 2005 while the remaining 17 countries did not adopt IFRS in 2005. Our main

\footnotetext{
${ }^{4}$ Many papers on market integration use country-level measures. In our setting, we choose firm-level measures because in a number of countries firms could voluntarily adopt IFRS (or its precedent IAS) before it was mandated nationwide. Country-level measures are based on all firms in a country and are thus unable to provide a clean test on the effect of mandatory IFRS adoption.

${ }^{5}$ For example, Bekaert and Harvey $(1995,403)$ point out that "If a market is segmented from the rest of the world, its covariance with a common world factor may have little or no ability to explain its expected return."
} 
analysis distinguishes between mandatory IFRS adopters and non-adopters. We classify as “mandatory adopters” firms that applied IFRS only after their countries mandated IFRS adoption in 2005. In contrast, "non-adopters" are firms that are located in non-adopting countries and apply domestic accounting standards throughout our sample period from 2003 to 2007.

Our univariate tests indicate that financial integration increased significantly after 2005 for both mandatory IFRS adopters and non-adopters. This evidence is consistent with the contention that barriers to financial integration have declined over time (Pukthuanthong and Roll 2009). However, the magnitude of improvement in financial integration is significantly greater for mandatory adopters than for non-adopters, suggesting that harmonizing accounting standards contributes effectively to global financial integration. We obtain similar results in multivariate analyses in which we control for various firm characteristics such as firm size, operational performance, stock liquidity, and analyst coverage, as well as industry fixed effects and country-level controls. Our results remain robust in a range of robustness tests, such as using US firms only as benchmarks, using different measures of global returns, using different databases and samples, controlling for financial reforms, and placebo tests.

We explore two channels through which mandatory IFRS adoption facilitates financial market integration. The first channel is the transmission of global information across markets. A uniform set of high quality accounting standards achieves accounting harmonization and consequently makes accounting information more comparable across markets, which, in turn, should allow investors to better interpret value-relevant information from global markets and to adjust local prices to incorporate the global information in a full and more timely manner. Consistent with this view, Tan et al. (2011) find that mandatory IFRS adoption helps local firms to attract coverage by foreign financial analysts and enables foreign analysts to issue more accurate forecasts for local firms. Wang (2014) finds that local firms’ stock prices respond more strongly to earnings news announced by foreign 
firms that use the same accounting standards as local firms, implying that comparable accounting information facilitates investors' response to global information contained in foreign firms' announcements. ${ }^{6}$ We thus expect that the effect of mandatory IFRS adoption on financial integration increases with the extent to which accounting harmonization related to IFRS adoption improves accounting comparability. To test this expectation, we use two measures of improvements in accounting comparability, one at country level and the other at firm level. The first measure is the difference between local GAAP and IFRS, with a larger difference indicating a larger improvement since the mandatory IFRS adoption eliminated the differences. The second measure follows De Franco et al. (2011) and Yip and Young (2012) and is an ex post measure of improvements in accounting comparability based on the mapping between stock returns and earnings using peer firms' data. With both measures of accounting comparability, we find that the effect of IFRS adoption on financial integration is more pronounced in adopting countries with greater improvements in accounting comparability.

The second channel is capital mobility and foreign equity investment. Prior studies have documented that IFRS adoption leads to an increase in foreign equity ownership (DeFond et al. 2011; Yu and Wahid 2014), and foreign investors are better able to incorporate global information into local share prices (Bae et al. 2012). We thus expect that IFRS adoption has a more pronounced impact on financial integration if the adoption contributes to larger improvements in foreign ownership. To empirically evaluate this contention, we examine whether the relation between financial integration and IFRS adoption is more pronounced when it is accompanied by a marked improvement in foreign investor ownership. Using institutional ownership data from the FactSet database to compute changes in foreign institutional ownership from the pre- to the post-mandatory IFRS adoption period, we find

\footnotetext{
${ }^{6}$ Note here that both local and foreign investors can better respond to global information from foreign firms if the information is more comparable. This implies that financial integration can be achieved even without foreign investment, as long as local investors can observe the global information and price local stocks according to their exposure to global risk factors.
} 
that the improvement in financial integration following IFRS adoption is greater when it is accompanied by a large increase in foreign ownership.

Our study contributes to the literature in several ways. First, it contributes to the growing literature on the effects of accounting standards, in particular the effects of mandatory IFRS adoption. Barth et al. (2008) compare domestic accounting standards to IAS and find that the latter contributes to higher quality accounting. Focusing on capital markets, prior research finds that IFRS adoption has a favorable impact on the cost of capital (Daske et al. 2008; Li 2010), stock liquidity (Daske et al. 2008), information content of earnings (Landsman et al. 2012), analyst forecast properties (Byard et al. 2011; Horton et al. 2013), and information transfers across countries (Kim and Li 2011; Wang 2014). Of particular relevance to this study is the positive impact of IFRS on the cost of capital. While prior studies explain the lower cost of capital following IFRS adoption by the reduction of information asymmetry or the improvement in information quality (Daske et al. 2008; Li 2010), our evidence suggests another potential explanation for this finding is the improvement in risk sharing due to increased financial integration, as documented in international finance literature (e.g., Henry 2000a).

Amiram (2012), DeFond et al. (2011), and Yu and Wahid (2014) find that IFRS adoption has a positive impact on foreign ownership of local stocks. These findings are important as they show the effectiveness of IFRS in improving the capital flow across geographic borders. However, improvements in capital mobility do not imply equivalent improvements in financial integration (Obstfeld and Taylor 2004). Our study complements this stream of research by providing direct evidence on the effect of mandatory IFRS adoption on financial market integration. Consistent with a uniform set of high quality accounting standards reducing information frictions across markets, we find that IFRS adoption induced accounting harmonization is positively associated with financial integration. We also show that the effect of IFRS adoption on financial integration is attributable to the impact of IFRS on capital mobility and global information flow. 
Our study also contributes to inquiry on the determinants of financial integration. A range of barriers may limit financial integration, including direct barriers that impose foreign ownership restrictions or limit the amount of direct ownership, or capital controls that restrict the amount of profits remitted or impose taxes on the flow of dividends and capital income (Bekaert 1995). Given these barriers, prior studies focused on whether regulatory changes such as market liberalization and political or currency union (e.g., Bekaert et al. 2002; Bekaert et al. 2013) contribute to market integration. Indirect barriers, such as information costs, also hinder financial integration and capital flows (e.g., Pownall et al. 2014). Our study provides empirical evidence that adopting a uniform set of higher quality accounting standards improves financial integration by reducing information frictions.

The remainder of this paper proceeds as follows. Section 2 reviews the relevant literature and develops hypotheses. Section 3 describes the sample construction and research design issues. Section 4 discusses empirical results, and Section 5 sets forth our conclusions.

\section{Related literature and hypothesis development}

Financial integration has received considerable attention in finance and economics research, partly because of its posited effects on the financial and real sectors of the economy (Bekaert et al. 2003; Henry 2003). The underlying argument is that financial integration lowers a firm's cost of capital by improved risk sharing and as a result positively affects investment and ultimately economic output (Henry 2003). Stulz $(1999,10)$ notes that "where barriers to international investment segment a national capital market from global markets, the local investors bear all the risk of the economic activities in their economy. And, for bearing this risk, such investors require a higher risk premium”. In the presence of integrated financial markets, foreign investors are allowed to invest in domestic markets and vice versa. Permitting cross-border investment improves risk sharing since a country's risk is borne by both foreign and local investors. In the presence of full financial integration, the 
resulting implication is that securities that have rights to identical streams of dividends but are issued in different countries will trade at the same price (Stulz 2005). More importantly, the cost of capital is posited to decline since the risk premium involved is adjusted for the risk sharing benefits due to financial integration (Errunza and Losq 1985; Stulz 1999). In support of this contention, Henry (2000a, 2000b) finds that improvements in integration through financial liberalization are associated with reductions in the cost of capital and increases in the level of investment.

Despite the posited benefits, there are barriers that limit the extent of financial integration. Extant literature identifies three classes of barriers (Bekaert 1995). The first class consists of legal barriers that impose specific restrictions or limits on foreign investor ownership. The second class of barriers involves risks related to a country's internal environment, including liquidity, political, economic, and currency risks (Bekaert et al. 2003). The third class of barriers is information related barriers or frictions that can arise from a lack of high quality, comparable accounting information (Bekaert 1995; Bekaert et al. 2003). Accounting statements represent an important source of firmspecific information for investors. For instance, they allow investors to better gauge the financial health of the firm and to evaluate its future prospects. Not surprisingly, Chuhan (1992) finds that investors view information frictions as impediments to cross-border investments.

In this study, we investigate whether accounting harmonization due to the mandatory adoption of IFRS can result in improvements in financial integration by removing information frictions associated with different accounting standards across markets. The aim of the International Accounting Standards Board in formulating IFRS is to "develop, in the public interest, a single set of high quality, understandable and enforceable global accounting standards that require high quality, transparent and comparable information in financial statements and other financial reporting to help participants in the world's capital markets and other users make economic decisions." ${ }^{77}$ In short, the

\footnotetext{
${ }^{7}$ The objective of IASB is available at: https://www.iasplus.com/en-gb/standards/other/preface.
} 
objectives can be summarized as aiming to achieve accounting harmonization. The most direct effect of adoption of a uniform set of accounting standards is the decrease in the cost of collecting and analyzing accounting information in the adopting countries. Since IFRS have been adopted in over 100 countries, it is now less costly for investors to compare and evaluate firms in the adopting countries around the world (Covrig et al. 2007). Even for global investors from non-adopting countries such as the US, the information cost associated with understanding IFRS appears to be a one-off cost since knowledge of IFRS can be applied to all firms in all the adopting countries. Furthermore, a uniform set of accounting standards implies that economic shocks to firms' fundamental operations will be recognized in accounting systems in a consistent way, which allows investors to better assess the systematic global risk and set local prices accordingly. Therefore, mandatory IFRS adoption can mitigate information barriers and facilitate financial integration by increasing the comparability of financial information around the world.

Consistent with this view, prior studies have documented that IFRS adoption facilitated crossborder information transfer and capital investments. DeFond et al. (2011) find improvements in accounting comparability due to IFRS adoption contribute to increases in foreign mutual fund ownership. Beneish et al. (2009) document a positive association between mandatory IFRS adoption and cross-border investments in not only equity but also bond markets. Related research also finds a positive association between IFRS adoption and foreign portfolio holdings (Yu and Wahid 2014), foreign individual investors (Bruggemann et al. 2009), and foreign analysts (Tan et al. 2011). The positive impact of IFRS adoption on cross-border investments is consistent with the argument that IFRS ameliorate the information frictions in the country involved.

IFRS adoption could also affect information frictions by altering the quality of financial reporting, although there is no conclusive evidence on whether adoption increases or decreases accounting quality. Some researchers note that IFRS adoption imposes a more comprehensive set of 
disclosure requirements than domestic accounting standards (Daske et al. 2008). It has also been argued that IFRS (and the predecessor IAS) constrain managerial discretion (Barth et al. 2008). Others, however, find that IFRS adoption leads to more earnings management and less conservative financial reporting (e.g., Lantto and Sahlström 2009; Ahmed et al. 2013; Lai et al. 2013). To the extent that IFRS adoption improves accounting quality, the adoption is likely to further reduce information friction to global investors because higher-quality accounting numbers can decrease information cost and estimation errors in assessing global risk factors.

Despite the argument that IFRS adoption mitigates information frictions by improving accounting comparability, it is far from certain that adopting IFRS will, in and of itself, improve financial integration. There are several reasons for this contention. First, other barriers in place such as political risk and capital controls may still serve to offset any benefit that results from adopting IFRS. Second, adoption of IFRS may not be perceived as a sufficient commitment to provide high quality and comparable financial reporting as firms can just adopt the label of IFRS without materially changing their reporting practice (Daske et al. 2013). Thirdly, although prior studies have documented that mandatory IFRS adoption led to increases in institutional ownership and foreign investment (DeFond et al. 2011; Florou and Pope 2012; Yu and Wahid 2014), there is no guarantee that the increase in foreign investment resulting from IFRS adoption improves financial integration. As mentioned earlier, the increases in foreign investment following IFRS adoption appear to be small in magnitude. It is unclear whether a small increase in foreign ownership can effectively improve financial integration. In addition, prior research suggests that other significant economic events that likely have a more profound effect on foreign investment and international trade do not necessarily affect financial integration. For example, Bekaert et al. (2013) show that the adoption of the Euro in a number of European countries did not result in greater financial integration despite the adoption removing the risk and transaction costs associated with currencies in the Euro zone. 
We consider two aspects of financial integration. One is the extent to which local stock returns are driven by global information. Research on financial integration often posits that equity returns reflect local and global risk factors (Lewis 2011), and financial integration refers to the relative roles of global and local risk factors in determining expected returns. For instance, Stulz (1981) considers a perfectly integrated setting and links the equity risk premium strictly to the covariance with global risk factors. Bekaert and Harvey (1995) hold the same view that in completely integrated markets stock returns are driven solely by global risk factors. In less than perfectly integrated markets, Errunza and Losq (1985) point to the effect of both local and global factors on expected returns. Pukthuanthong and Roll (2009) propose that countries are more integrated if their stock returns are more subject to the global factors. Therefore, greater financial integration implies greater impact of global factors, relative to local factors, on expected stock returns. To the extent that IFRS adoption facilitates financial integration, it leads to our first testable hypothesis (in the alternative form):

H1: Mandatory IFRS adoption increases the extent to which local stock returns are driven by global risk factors.

The other aspect of financial integration is improved stock price efficiency in terms of the timeliness with which global news is incorporated into stock prices. The intuition here is that financial integration facilitates the cross-market transmission of value relevant information, so that global information is incorporated in local prices without delay. Bae et al. (2012) argue and find that removing foreign investment restrictions attracts global investors who are better at collecting and processing global news, and thus positively impacts the speed at which global news is incorporated into stock prices. Wang (2014) shows that after IFRS adoption, local stock prices react more strongly to earnings announcements by foreign firms that also use IFRS for financial reporting. The evidence suggests that IFRS adoption facilitates the transmission of earnings news across markets. To the 
extent that mandatory IFRS adoption reduces information frictions, it leads to the following testable hypothesis (in the alternative form):

H2: IFRS adoption improves the speed with which global news is incorporated into stock prices.

\section{Sample, empirical model, and variable construction}

Our initial sample selection starts with firm-level data from the countries included in the Compustat Global database for which we have information available on the accounting standards classification (data item “astd") and daily prices. Among the countries, 18 countries initiated mandatory adoption of IFRS in $2005 .{ }^{8}$ We restrict the adoption year to 2005 so that we can use the same pre-period (years 2003 to 2004) and post-period (years 2006 to 2007) for all sample firms. ${ }^{9}$ This requirement removes Singapore from our sample due to its early mandatory IFRS adoption in 2003. For each of the IFRS-adopting countries, we define mandatory adopters as firms that used local GAAP before 2005 and switched to IFRS after $2005^{10}$ (i.e., firms whose astd is equal to "DS" in the pre-period and "DI" in the post-period). ${ }^{11}$ We then combine the remaining countries covered in Compustat Global with the US and Canadian firms covered in Compustat North America to form our

\footnotetext{
${ }^{8}$ Prior studies often list Hong Kong and Switzerland as adopting countries, but they did not mandate IFRS for domestically listed firms despite the widespread use of IFRS (Nobes and Zeff 2016). Our sample excludes firms from these two markets, although including them does not change our results.

${ }^{9}$ We exclude year 2005 from our analyses to avoid the potential for confounding effects in the transition year. The post-period ends in 2007 to avoid any potential effects of the financial crisis in 2008.

${ }^{10}$ European Commission mandated IFRS for financial reporting starting with fiscal years beginning on or after January 1, 2005. This means that a firm could effectively initiate IFRS adoption in fiscal year 2006 if its fiscal year 2005 began before January 1, 2005. Furthermore, a few adopting countries allowed smaller firms to delay IFRS adoption until 2006. Our sample includes these "late adopters", but excluding the "late adopters" from the sample does not alter our results and inferences. It is also worth noting that, due to various exemptions and deferrals, a substantial portion of firms in the European Union did not adopt IFRS for financial reporting until 2009 (Pownall and Wieczynska 2017). Our sample of interest thus is the firms that started using IFRS in 2005 or 2006, rather than all firms in IFRS adopting countries.

11 "DS" stands for "Domestic Standards" and "DI" indicates domestic standards generally in accordance with or fully compliant with International Financial Reporting Standards (IFRS). We also cross check the accounting standards classification with the data item "IFRS" in the Datastream database. Whenever there is a conflict between the two databases, we exclude the observation.
} 
control sample of non-IFRS countries, i.e., countries that did not require IFRS adoption (i.e., astd is equal to “DS,” or “US” for US firms, throughout our sample period).

Finally, we remove the Philippines from the group of mandatory IFRS adoption countries and Russia from the group of non-IFRS countries because each has only two firms identified as mandatory or non-adopters. ${ }^{12}$ Another non-adopting market, Taiwan, is dropped from the sample because we cannot obtain country-level control variables from the World Bank database. To ensure the results are not due to different sample composition in the pre- and post-periods, we require each firm to have four full years of data. This leaves a final sample consisting of 9,148 firm-year observations of mandatory adopters from 17 mandatory IFRS adopter countries, and 42,280 firm-year observations of non-adopters from 17 non-IFRS adopter countries.

\section{Dependent variables: Measures of financial integration}

We measure two firm-level implications of financial integration developed in the extant finance literature. Our first measure is the extent to which a firm's stock returns are explained by global information. International finance literature typically assumes that local stock returns are driven by local factors and global factors. In the absence of financial integration, local factors determine local stock returns with little role played by global factors. In the presence of complete financial integration, the "relevant source of systematic risk becomes the world market" (Chari and Henry 2004), and local prices are determined by the securities' exposure to global risk factors. Therefore, improvements in financial integration should increase the extent to which a stock's returns are tied to the global rather than to the domestic market portfolio (Gultekin et al. 1989; Korajczyk and Vialet 1989; Errunza et al. 1992; Chari and Henry 2004). Pukthuanthong and Roll (2009, 214) argue that "A sensible intuitive quantitative measure of financial market integration is the proportion of a country's returns that can be explained by global factors.” In light of this argument, we measure the

\footnotetext{
${ }^{12}$ Including these two countries does not alter our findings.
} 
extent to which a stock is integrated into global markets by the proportion of its stock returns that can be explained by global returns, scaled by the portion that can be explained by both local and global returns. Specifically, we estimate the following time-series equation for each stock using its weekly stock returns across a year:

$$
R_{i, t}=\alpha+\sum_{k=0}^{3} \delta_{i, k} R_{g, t-k}+\sum_{k=0}^{3} \gamma_{i, k} R_{l, t-k}+\varepsilon_{i, t}
$$

where $R_{i, t}$ denotes the return on stock $i$ in week $t$, and $R_{g, t-k}$ and $R_{l, t-k}$ are the contemporaneous and lagged weekly returns on the global market portfolio and the local market portfolio, respectively, for $k$ $=0,1,2,3$. The local market returns and global market returns are measured by the weekly returns of the Morgan Stanley Capital International (MSCI) Country Index and the MSCI World Index from Datastream. $^{13}$

We label R-squares from regression (1) as $R^{2}$ _total. We then re-estimate the model by excluding local market portfolio returns:

$$
R_{i, t}=\alpha+\sum_{k=0}^{3} \delta_{i, k} R_{g, t-k}+\varepsilon_{i, t}
$$

The R-squares from this restricted model are denoted as $R^{2} \_$global. Our firm-specific measure of financial integration (INTEGRATE) is the ratio of $R^{2} \_$global to $R^{2} \_$total.

We note that Equation (1) essentially assumes that stock returns are driven by a local factor and a global factor, as well as by their lags. $R^{2}$ _total captures the explanatory power of these systematic factors, while $R^{2}$ global captures the explanatory power of the global factor. ${ }^{14}$ The ratio of $R^{2}$ global to $R_{-}^{2}$ total thus measures the relative explanatory power of the global factor. The higher the ratio, the greater the influence of the global factor on firm-specific stock returns, and therefore the greater the level of financial integration of the underlying market involved.

\footnotetext{
${ }^{13}$ The choice of weekly returns follows Bae et al. (2012) to minimize the effect of potential biases associated with nonsynchronous trading. The weekly returns are computed as compounded returns from Wednesday to Tuesday, to avoid a possible weekend effect. To mitigate the effect of data errors and extreme values, we delete weekly returns at the top and bottom $1 \%$ of their distributions. We require at least 20 weekly observations to be available for each stock in each year.

${ }^{14}$ Table A1 in the online Appendix reports the mean $R^{2} \_t o t a l$ and $R^{2}$ global for each country.
} 
Our second measure of financial integration, the speed with which local stock prices include global information, is related to the theoretical argument that greater financial integration produces more efficient stock prices. It is also based on Equation (1). In a well-integrated market with little friction, stock prices are expected to react to global information without delay. Following Bae et al. (2012), we estimate a restricted version of Equation (1) by setting the coefficients of lagged global portfolio returns at zero:

$$
R_{i, t}=\alpha+\delta_{i, t} R_{g, t}+\sum_{k=0}^{3} \gamma_{i, k} R_{l, t-k}+\varepsilon_{i, t}
$$

Bae et al. (2012) propose that the delay with which stock prices incorporate global information can be measured by the proportion of stock returns that is explained by lagged global portfolio returns. Specifically, their delay measure (Delay) is calculated as one minus the ratio of R-squared from Equation (3), $R_{-}^{2} g r$, to R-squared from Equation (1), $R^{2}$ total. We define SPEED as (1 - Delay), or

simply $\frac{R_{-g r}^{2}}{R_{-t o t a l}^{2}}$. In a more integrated market, global information is incorporated into stock prices at a faster pace, so lagged global returns will explain a relatively smaller proportion of stock returns, resulting in higher values for our SPEED variable.

\section{Regression models}

To test our hypothesis that mandatory IFRS adoption facilitates financial integration, we take a difference-in-difference approach where the mandatory adopters form the test group and the nonIFRS adopters serve as the control group. In particular, we estimate the following equation:

$$
D E P_{i, t}=\beta_{0}+\beta_{1} \text { Mandatory }_{i, t}+\beta_{2} \text { Post }_{i, t}+\beta_{3} \text { Mandatory }_{i, t} \times \text { Post }_{i, t}+\text { Control }_{i, t-1}+\varepsilon_{i, t}
$$

where the dependent variables $(D E P)$ are the measures of financial integration (INTEGRATE and SPEED) for firm $i$ in year $t$, as defined previously. Mandatory is an indicator variable that equals one for firms in countries that had undertaken mandatory adoption of IFRS in 2005, and zero for firms from the control group of non-IFRS countries. Post is an indicator variable that equals one for observations in the post-mandatory IFRS adoption years (2006 and 2007), and zero for observations 
in the pre-adoption period (2003 and 2004). Our variable of interest is the interaction term, Mandatory $_{i, t} \times$ Post $_{i, t}$, which captures the changes in financial integration due to mandatory IFRS adoption, benchmarked against changes in financial integration that arise in the control group (i.e., non-adopters). The coefficient on this interaction variable is depicted as follows: $\beta_{3}=\mathrm{E}\left(D E P\right.$ of treatment group ${ }_{\text {post }}-D E P$ of treatment group $\left.p_{p r e}\right)-\mathrm{E}\left(D E P\right.$ of control group post $_{-}$ $D E P$ of control group ${ }_{p r e}$ ). If mandatory IFRS adoption improves financial integration, we expect a positive value for $\beta_{3}$ for both measures of financial integration (INTEGRATE and SPEED).

Extant literature identifies several factors that may impact financial integration. Hou and Moskowitz (2005) suggest that investor attention and liquidity affect how actively investors engage in information searching and trading, so we control for these two factors by including measures of firm size (Size), share turnover (Turnover), return volatility (Volatility), analyst coverage (AnalystCover), and trading activity (TradingDay) in our empirical model. Size is measured by the natural logarithm of market value of equity. Turnover is measured as the weekly average of trading volume divided by the total number of shares outstanding. Volatility is measured by the standard deviation of weekly stock returns. AnalystCover is an indicator variable equal to one if at least one analyst issues annual earnings forecasts for the firm, and TradingDay measures the number of days the stock is actively traded. Further, we include an indicator variable (Loss) for firms reporting negative operating income to control for the differential pricing process for loss firms (Callen, Khan and Lu 2013). Finally, we control for investor recognition by including two indicator variables, IndexStock which indicates membership of MSCI Country Index, and ADR which indicates American Depositary Receipt (ADR) stock. In addition to the above firm-level controls, we also consider country-level control variables. GDP is the natural logarithm of Gross Domestic Product (GDP); MktCap_GDP is the ratio of the country's total market capitalization to GDP; GDPGrowth is the growth rate of GDP; and Trade is the 
country's total amount of exports plus imports, scaled by the country's GDP. The definitions and data sources for all variables are provided in the Appendix.

The control variables are measured in year $t-1$ to minimize potential endogeneity concerns. As suggested in Hou and Moskowitz (2005) and Callen et al. (2013), we expect a negative coefficient for the variable Loss and positive coefficients for the other control variables. To control for systematic variation across industries, we include industry fixed effects in all regressions where an industry is defined on the basis of the one-digit Standard Industry Code. We estimate Equation (4) using OLS regressions and adjust standard errors for clustering at the firm level.

\section{Descriptive statistics}

Table 1 reports the distribution of mandatory adopters in adopting countries, and non-IFRS adopters in non-adopting countries. For our sample of mandatory adopters, while the number of unique firms and firm-year observations varies substantially across countries, the pattern is similar to that revealed in other studies. For example, our mandatory adopters sample shows that the United Kindom has the highest number of firm-year observations (2,336), and Austria has the lowest number of observations (36). The non-adopter sample also shows a large range of variation across countries, with the US (17,808 firm-year observations) representing $42 \%$ of the sample and Peru having the lowest number of firm-year observations (24).

\section{[Insert Table 1 Here]}

Panel A and B in Table 2 present the descriptive statistics for financial integration measures and control variables for each type of firm in the pre- and post-adoption periods. The mandatory adopters have a higher mean value of INTEGRATE than the non-adopters. This evidence suggests that relative to non-adopters, adopters of IFRS tend to have stock returns that are more influenced by global factors. SPEED for mandatory adopters appears to be slightly lower than SPEED for nonadopters, suggesting that on average stock prices of IFRS adopters have a more delayed reaction to 
global information than that of non-adopters. This pattern is consistent in both pre- and post-adoption periods, and the contrast between INTEGRATE and SPEED suggests these two variables capture different aspects of financial integration.

There are also significant differences in firm characteristics between the mandatory adopters and non-adopters. Relative to mandatory adopters, non-adopters are larger and have more loss-making years, higher share turnover, more volatility in stock returns, and lower likelihood to be followed by analysts. Voluntary adopters tend to be larger and have more analyst coverage than mandatory adopters. Again, these characteristics are consistent with those documented in prior studies (e.g., Daske et al. 2008; Byard et al. 2011). These differences suggest the importance of multivariate analysis where we control for factors that also contribute to the difference in financial integration across groups.

[Insert Table 2 Here]

Table 3 reports the Pearson and Spearman correlation coefficients between the variables. As expected, INTEGRATE and SPEED are positively correlated, with a Pearson correlation coefficient of 0.273 and a Spearman correlation coefficient of 0.257 , both of which are statistically significant at the 5\% level. Both INTEGRATE and SPEED are positively related to stock turnover, the number of trading days, analyst coverage, inclusion in market indexes, and cross listing status, consistent with the expectation that better liquidity, information environment and international visibility facilitate the incorporation of global information into local prices. Stock return volatility and accounting loss are negatively related to both measures of financial integration. However, while INTEGRATE is negatively associated with firm size, GDP growth and foreign trade, SPEED is positive related to these variables. The evidence suggests that the two measures of financial integration are positively related but capture different dimensions of financial integration.

[Insert Table 3 Here] 


\section{Empirical results}

\section{Univariate tests}

We begin our analysis with a univariate test comparing the means of the integration measures before and after 2005 for mandatory IFRS adopters and non-adopters. The results, reported in Table A2 in the online Appendix, show that mandatory adopters experience an increase of 0.061 (= $0.652-$ 0.591) in INTEGRATE after 2005 while non-adopters had an increase of 0.017 (= $0.555-0.538)$. This suggests that both groups of firms display greater stock price sensitivity to global factors over time. In light of prior research, this finding is not surprising since there is a global move towards easing the restrictions on capital flows. Although both increases are statistically significant, the increase in INTEGRATE for mandatory adopters is over three times greater than that of non-adopters, and the difference between these two groups (0.044) is statistically significant at the $1 \%$ level. This is similar for SPEED: both mandatory adopters and non-adopters experienced an increase in SPEED, which suggests that stock prices of both groups of firms respond in a more timely manner to global information after 2005 than before. But the increase in SPEED for mandatory adopters (0.036) is double that of non-adopters (0.017). The difference between these two groups (0.019) is also statistically significant at the $1 \%$ level.

The results from univariate tests are consistent with the hypotheses that mandatory IFRS adoption contributes to greater financial integration. Nevertheless, the improvement in integration of non-adopters suggests that changes besides IFRS adoption also contribute to financial integration. Hence, we conduct multivariate analysis to better isolate the effects of mandatory IFRS adoption on financial integration.

\section{Multivariate analyses of mandatory adopters and non-adopters}


Table 4 reports the multivariate regression results involving measures of financial integration. Columns (1) to (3) report the results where the dependent variable is INTEGRATE. Column (1) provides a baseline model where we regress INTEGRATE, Post, the interaction term Mandatory $\times$ Post, and industry fixed effects. Our primary variable of interest is the interaction term Mandatory $\times$ Post.

In Column (1), the coefficient of the interaction term, $\beta_{3}$, is positive and statistically significant (coefficient $=0.047, p$-value $<0.001$ ). This suggests that relative to non-adopters, mandatory adopters experienced a larger increase in INTEGRATE. These results are quite similar to those from univariate tests in Table 3 and consistent with hypothesis 1. Column (2) adds variables to control for firm characteristics related to financial integration and country fixed effects to control for any potential omitted country-level variables. The coefficient on the interaction term Mandatory $\times$ Post continues to be significantly positive (coefficient $=0.032, p$-value $<0.001$ ), which suggests that the incremental positive impact of mandatory IFRS adoption on INTEGRATE is not due to changes in firm characteristics or omitted country-level factors. Column (3) includes control variables for firm characteristics and replaces the country fixed effects with time varying country-level variables including a country's GDP, GDP growth rates, financial development, and international trade. The coefficient on the interaction term Mandatory $\times$ Post remains positive (0.031) and statistically significant at the $1 \%$ level. $^{15}$

Columns (4) to (6) report the regression results where the dependent variable is SPEED. The coefficient on the interaction term Mandatory $\times$ Post is positive (0.023) in Column (4) and significant at the $1 \%$ level, suggesting that relative to non-adopters, mandatory adopters experienced a

\footnotetext{
${ }^{15}$ Note the dependent variable in Columns 1 to 3, INTEGRATE, is the ratio of the R-squared from Equation (2), $R^{2}$ global, to the R-squared from Equation (1), $R^{2}$ total. One concern is that the observed increase in INTEGRATE is not due to an increase in $R^{2}$ global, but due to a decrease in the denominator $R_{-}^{2}$ total. In untabulated results, we find the $R^{2}$ total does not decrease during our sample period. Actually, relative to nonadopters, mandatory adopters experienced a significant increase in $R^{2}$ total after 2005, suggesting our results are not driven by a decrease in the denominator of INTEGRATE.
} 
larger increase in the speed with which global information is incorporated into stock prices after 2005. We obtain similar results in Column (5) where we add country fixed effects, and in Column (6) where we include control variables involving firm and country attributes.

In sum, the results in Table 4 support our hypotheses: relative to non-adopters, mandatory IFRS adopters experienced a larger improvement in financial integration. This finding suggests that IFRS adoption increased the degree to which local prices are driven by global information. IFRS adoption also led to higher stock price efficiency and timeliness in the recognition of global information in stock prices. These results hold after we control for industry fixed effects and various firm and country characteristics.

Given the way that financial integration is measured by INTEGRATE and SPEED, it is difficult to assess the economic significance of the increase in financial integration. However, a comparison between mandatory adopters and non-adopters indicates the relative significance of the effect of IFRS adoption on financial integration. Take Column (4) as an example. After controlling for firm characteristics and country fixed effects, the coefficient on Post $(0.029, p$-value $<0.001)$ suggests that for non-adopters, the increase in the speed at which global information is incorporated into their stock returns after 2005 is 0.029 . Mandatory adopters experienced an improvement of 0.046 $(=0.029+0.017)$ in $S P E E D$, representing a $6.2 \%$ increase in the speed of global information being incorporated into mandatory adopters' stock prices. ${ }^{16}$ For comparison, Bae et al. (2012) examine the effect of restrictions on foreign investment in emerging markets on the speed of price adjustment to global information. Their estimates (Table 4, p217) show that SPEED improves by $18.5 \%$ if the proportion of shares that can be invested by foreigners increase by $91 \% .{ }^{17}$ The relative magnitudes

\footnotetext{
${ }^{16}$ This is calculated as 0.046 (the sum of the coefficients of Post and Mandatory $\times$ Post) divided by 0.741 (the mean SPEED for mandatory adopters in the pre IFRS adoption period, as reported in Panel A Table 2).

${ }^{17}$ Bae et al. (2012) show that one standard deviation increase in investible weight is associated with a decrease of $18.5 \%$ in a measure of price delay. One standard deviation increase, or 0.384 , is equivalent to $91 \%$ in the mean investible weight since the mean is 0.42 as shown in their Table 2 .
} 
involved here suggest that the adoption of IFRS had an economically significant impact on financial integration.

\section{[Insert Table 4 Here]}

We conduct a number of robustness tests to ensure that our results in Table 4 are not driven by a few specific countries in the sample. The sample distribution in Table 1 shows that US firms dominate the non-adopter sample, accounting for $42 \%$ of non-adopter observations. One concern is whether our results are sensitive to the use of the US as a benchmark non-adopting country. To address this concern, we divide non-adopters into two groups - US firms and non-US firms, and compare mandatory adopters to these two groups separately. The results reported Table A3 in the online Appendix show that the finding of IFRS adoption associated with increased financial integration holds when we use either the US-only firms as the control group or all other non-adopters as the control group. ${ }^{18}$ In further robustness tests, we show that the results in Table 4 remain unchanged if we exclude China and New Zealand from the non-adopters sample since these two countries had significant convergence of local GAAP toward IFRS in the mid 2000s, or if we restrict the adopting countries to those located in Europe or members of the European Union. Results from these two robustness tests are reported in Tables A4 and A5 in the online Appendix, respectively. Hence, the results from robustness tests verify that the increase in financial integration is not sensitive to the choice of control group or treatment groups.

\section{Cross-sectional variation among the adopting countries}

In this section, we focus on the mandatory adopting countries and examine whether the association between financial integration and IFRS adoption varies with institutional factors, change

\footnotetext{
${ }^{18}$ Alternatively, we follow prior research such as Dittmar et al. (2003) and estimate a weighted least squares (WLS) model where each observation is weighted by the inverse of the number of observations in each country. This ensures that each country receives equal weight in the estimation. Our results in Table 4 continue to hold in all the WLS regressions.
} 
in foreign investment, and improvement in accounting comparability in the direction as predicted. This exercise helps to attribute the observed increase in financial integration to IFRS adoption. In particular, we conjecture that mandatory IFRS adoption is likely to facilitate financial integration through two related channels. First, IFRS adoption facilitates cross-border transmission of global information by harmonizing accounting standards (Wang 2014). Second, IFRS adoption attracts more foreign investors who are better able to incorporate global information into local prices (DeFond et al. 2011; Bae et al. 2012). For the first channel, we expect that countries and firms that benefit most from the harmonization of accounting standards will have a larger improvement in financial integration. For the second channel, we predict that mandatory adopters that experience a larger increase in foreign ownership will have a larger improvement in financial integration.

To test these predictions, we construct measures of accounting comparability and collect data on foreign ownership. We then divide mandatory adopters into two subsamples based on the changes in accounting comparability and changes in foreign ownership. For each subsample, we estimate the following regression:

$$
D E P_{i, t}=\beta_{0}+\beta_{1} \text { Post }_{i, t}+\text { Control }_{i, t-1}+\varepsilon_{i, t}
$$

where DEP is either INTEGRATE or SPEED. The variable of interest is Post, which indicates the improvement in financial integration after mandatory adoption of IFRS in the subsamples.

\section{Analysis of accounting comparability}

We start with examining the effect of accounting harmonization on financial integration. Following DeFond et al. (2011) and Wang (2014), our measure of the degree of accounting harmonization is the difference between IFRS and local GAAP. A larger difference indicates the mandatory adopters experience a larger improvement in the comparability of their accounting numbers and benefit more from accounting harmonization. From Bae et al. (2008), we obtain a 
measure of the extent to which IFRS differs from local GAAP, which is the number of differences between IFRS and local GAAP on the accounting treatment of 21 items. ${ }^{19}$

We partition the mandatory adopting countries into two groups based on whether their GAAP differences are above (Large) or below (Small) the sample median. Table 5 reports the results from regressions using mandatory adopters in each subsample. In Column (1), we find a significant increase in INTEGRATE for the Large GAAP Difference subsample $\left(\beta_{1}=0.040, p\right.$-value $\left.<0.001\right)$. Column (2) shows that the increase in INTEGRATE is statistically insignificant for the Small GAAP Difference subsample $\left(\beta_{1}=0.001, p\right.$-value $\left.=0.884\right)$. The difference in $\beta_{1}$ is statistically significant at the $1 \%$ level. ${ }^{20}$ We find similar evidence for SPEED in Columns (3) and (4). This result suggests that the impact of mandatory IFRS adoption on financial integration is greater in countries where there is a large difference between local GAAP and IFRS, consistent with our prediction.

[Insert Table 5 Here]

An issue in the mandatory IFRS adoption literature is whether firms truthfully adopt IFRS or only adopt the label of IFRS without changing their accounting practice (Daske et al. 2013). DeFond et al. (2011) argue that firms are more likely to truthfully implement IFRS in countries with a stronger legal system and law enforcement. Following this argument, we use the accounting enforcement index compiled by Brown, Preiato and Tarca (2014) to capture a country’s strength in enforcement of IFRS in local markets. We combine GAAP Differences and accounting enforcement index to identify the countries that are most likely to benefit from a credible IFRS adoption. In particular, we follow DeFond et al. (2015) and classify mandatory IFRS adopter countries into two groups. The first group, labeled as "Strong", includes countries that have above-median accounting enforcement and above-

\footnotetext{
${ }^{19}$ Table A6 in the online Appendix reports the GAAP differences and accounting enforcement index for each country in the sample.

${ }^{20}$ To test whether the coefficients are statistically significant, we combine the samples of the two groups and include an interaction between Post and GAAP difference in regressions. The interaction term captures the difference in the coefficients of Post for the two groups. The $p$-value for the difference in $\beta_{1}$ reported in Table 6 is based on the coefficient and standard errors of this interaction term.
} 
median difference between local GAAP and IFRS. All other adopting countries are classified into the second group, which we label "Others”. We then estimate Equation (6) separately for each group. The results, reported in Table A7 in the online Appendix, show that in both regressions using INTEGRATE and SPEED as the dependent variables the coefficients of Post are larger in the "Strong" group than those in the "Others" group. The difference in coefficients for these two groups is statistically significant, suggesting that the mandatory adopters located in countries with large differences between local GAAP and IFRS that can credibly implement IFRS experienced a larger improvement in financial integration.

We also use an alternative measure of accounting comparability to provide further support to the prediction. Following De Franco et al. (2011) and Yip and Young (2012), we measure accounting comparability based on the average absolute value of the difference between a firm's expected earnings using the accounting function in its own industry and home country and the expected earnings using the accounting function in the same industry but from foreign countries. As a first step, we estimate the following regression for each country-industry-year: $R O A_{\mathrm{i}, \mathrm{j}, \mathrm{k}, \mathrm{t}}=\alpha_{\mathrm{j}, \mathrm{k}, \mathrm{t}}+\beta_{\mathrm{j}, \mathrm{k}, \mathrm{t}} R E T_{\mathrm{i}, \mathrm{j}, \mathrm{k}, \mathrm{t}}+$ $\varepsilon_{\mathrm{i}, \mathrm{j}, \mathrm{k}, \mathrm{t}}$, where $R O A$ is the income before extraordinary items divided by total assets, $R E T$ is the annual stock returns, and subscripts $i, j, k, t$ indicate firm, industry, country and year, respectively. The expected earnings using a firm's home country accounting function is the predicted value from the regression: $\mathrm{E}_{\mathrm{k}}(R O A)=\alpha_{\mathrm{j}, \mathrm{k}, \mathrm{t}}+\beta_{\mathrm{j}, \mathrm{k}, \mathrm{t}} R E T_{\mathrm{i}, \mathrm{j}, \mathrm{k}, \mathrm{t}}$. Then for each industry-country-year combination, we use all the firms in the same industry but located in foreign countries to estimate the regression $R O A_{\mathrm{m}, \mathrm{j}, \mathrm{n}, \mathrm{t}}=$ $\gamma_{\mathrm{j}, \mathrm{k}, \mathrm{t}}+\delta_{\mathrm{j}, \mathrm{n}, \mathrm{t}} R E T+\varepsilon_{\mathrm{m}, \mathrm{j}, \mathrm{n}, \mathrm{t}}$. The expected earnings using foreign countries' accounting function is $\mathrm{E}_{\mathrm{n}}(R O A)$ $=\gamma_{\mathrm{j}, \mathrm{n}, \mathrm{t}}+\delta_{\mathrm{j}, \mathrm{n}, \mathrm{t}} R E T_{\mathrm{i}, \mathrm{j}, \mathrm{k}, \mathrm{t}}$ The average value of $\left|\mathrm{E}_{\mathrm{k}}(R O A)-\mathrm{E}_{\mathrm{n}}(R O A)\right|$ is used as a measure of accounting comparability, with small values indicating more comparable accounting systems. The improvements in accounting comparability in a country are then measured by taking the difference between the average accounting comparability in the pre-IFRS period and post-IFRS period. Unlike GAAP 
difference, this alternative measure is based on realized accounting numbers and thus presents an ex post measure of improvements in accounting comparability. We expect firms with large improvements in accounting comparability to have greater increase in financial integration.

We classify firms whose improvement in accounting comparability is above the top quartile in the sample as the large improvement group and leave other firms in the small improvement group. We then estimate Equation (6) separately for each group. Table 6 reports the results. Columns (1) and (2) show that both the large and small improvement groups experience a significant increase in INTEGRATE after IFRS adoption. However, the coefficient on the variable of interest, Post, for the large group (0.044) is larger than that of the small group (0.026). The difference in the coefficients is statistically significant ( $p$-value=0.076). In the regressions involving SPEED in Columns (3) and (4), the coefficient on Post for the large group is 0.029 ( $p$-value=0.016) but for the small group it is 0.006 ( $p$-value $=0.382)$. The difference between these two groups is significant at the $5 \%$ level ( $p$ value $=0.023$ ). The results show that the impact of IFRS adoption on financial integration is more pronounced when it is accompanied by large improvements in accounting comparability. This finding provides further support to our prediction that mandatory IFRS adoption improves financial integration by making accounting information more comparable and facilitating cross-border transmission of global information.

\section{[Insert Table 6 Here]}

\section{Analysis of change in foreign investment}

To examine whether IFRS adoption improves financial integration by attracting more foreign investors to local markets, we obtain firm-level foreign institutional ownership information from the FactSet database. We use these data to identify and measure the increases in foreign institutional ownership around the mandatory IFRS adoption. Specifically, for each mandatory adopter in the sample, we calculate the increases in foreign institutional ownership by using the mean foreign 
ownership in the post-IFRS period (2006 and 2007) minus the mean foreign ownership in the preIFRS period (2003 and 2004). We partition the mandatory adopters into two subsamples based on whether their increases in foreign institutional ownership are above (Large) or below (Small) the third quartile in the sample. Due to missing data on foreign institutional ownership, we have a reduced sample of 1,569 firm-year observations for this analysis. We expect firms that experienced large increases in foreign institutional ownership to have greater improvement in financial integration.

Columns (1) and (2) of Table 7 present the results of the regressions of INTEGRATE carried out separately for the subsamples. For both subsamples, the variable Post has a positive and significant coefficient. However, the coefficient is much larger in the subsample of firms with a large increase in foreign institutional ownership. The difference in the coefficients is statistically significant ( $p$-value $=0.035$ ), indicating that firms with a larger increase in foreign institutional ownership experienced a greater increase in INTEGRATE. Next, we turn to the regressions involving the other measure of financial integration, SPEED, in Columns (3) and (4) of Table 7. The results show that the coefficient on Post is positive for both subsamples, but it is statistically significant only for the subsample of firms with a large increase in foreign institutional ownership. The difference in the coefficients across the two subsamples is statistically significant, suggesting that individual stock returns incorporate global news in a more timely manner following IFRS adoption when IFRS adoption leads to a larger increase in foreign institutional ownership.

In sum, the results in Table 7 show that improvements in financial integration after IFRS adoption are more pronounced when adoption is accompanied by an increase in foreign investment. This evidence suggests that mandatory IFRS adoption facilitates financial integration by attracting foreign investors who are better able to incorporate global information into local stock prices.

[Insert Table 7 Here]

\section{Robustness checks}


To further evaluate the robustness of our findings, we run a range of additional analyses. This sub-section discusses the findings of these analyses with the results reported in the online Appendix.

\section{Effect of concurrent changes}

It has been noted that mandatory IFRS adoption is accompanied by some concurrent changes in the adopting countries, such as changes in legal enforcement and auditing standards. In particular, Christensen et al. (2013) examine and find that the effects of mandatory IFRS adoption on liquidity are more pronounced in countries which concurrently improved the legal enforcement of accounting practices, while the liquidity effects are absent in other countries. Their results suggest that the documented effects associated with IFRS adoption could be compounded by the concurrent changes in adopting countries. ${ }^{21}$ To address this concern, we conduct three additional tests. First, we examine whether the association between financial integration and mandatory IFRS adoption is impacted by changes in the legal regime. We identify and distinguish observations from the five countries which experienced significant changes in the legal regime as identified by Christensen et al. (2013): Finland, Germany, Netherlands, Norway, and the United Kingdoms. The results, reported in Table A8 in the online Appendix, find mandatory IFRS adoption has a positive impact on financial integration in these five countries and in other adopting countries. We do not find a systematically stronger relation between financial integration and IFRS adoption in these five countries relative to other countries. The evidence suggests that the effect of IFRS adoption on financial integration is not confined to the five countries of concurrent law enforcement changes identified by Christensen et al. (2013).

Second, we examine the financial reforms taking place concurrently with mandatory IFRS adoption since financial reforms could make the local markets more integrated into global markets. In

\footnotetext{
${ }^{21}$ We understand there is an ongoing debate on whether IFRS adoption per se can explain various effects of the adoption documented in the literature. Although it is not our intention to resolve the debate, we think it is important to consider more evidence from various settings and variables besides the liquidity effect that Christensen et al. (2013) examine. At the same time, we acknowledge that many institutional factors are interdependent and work together to shape the outcomes of financial reporting (Isidro, Nada and Wysocki 2016). IFRS adoption, together with accompanying institutional changes, can be perceived as a "package" that collectively influences adopting firms' integration into global markets.
} 
a robustness test, we control for the level of financial reforms surrounding the year 2005, using the financial reforms data constructed by Abiad et al. (2008). Results reported in Table A9 in the online Appendix show that our results remain unchanged after including of this additional control variable in the regression models.

Third, a few stock exchanges in European countries joined Euronext in early 2000s and in 2007 Euronext merged with New York Stock Exchange. Pownall et al. (2014) show that Euronext helped reduce frictions in stock trading and investors' home bias, potentially contributing to financial integration. To control for this concurrent change, we separate adopting countries into two groups based on whether their stock exchanges are a member of Euronext before 2005. We then re-estimate the main regression for each group and report the results in Table A10 in the online Appendix. The results show that, for both groups, the coefficients of the interaction term Mandatory $\times$ Post remain positive and statistically significant in regressions with INTEGRATE and SPEED as dependent variables. Our results hence suggest that IFRS adoption has an incremental effect on integration that is not subsumed by the formation of Euronext.

Within adopting country comparison: mandatory adopters vs. voluntary adopters

In some adopting countries, some firms voluntarily adopted IFRS or its predecessor IAS prior to 2005. The presence of these voluntary IFRS adopters allows us to examine whether mandatory IFRS adoption has an incremental effect on voluntary adopters in relation to financial integration. There are several reasons why an IFRS adoption mandate may also benefit these voluntary adopter firms. First, voluntary IFRS adoption may not be comprehensive since it is influenced by managerial discretion (Kim and Shi 2012). As a result, mandatory IFRS adoption may impact voluntary IFRS adopters insofar as it compels them to increase their commitment to complying with IFRS. Second, the rate of voluntary IFRS adoption is quite low (around 9\%, according to Kim and Shi 2012). In this instance, the passage of mandatory IFRS adoption can generate positive information-related 
externalities. Principally, mandatory IFRS adoption may serve to improve the comparability of the voluntary adopters to their peer firms. Again, the benefit is that mandatory IFRS adoption may positively affect the information environment of voluntary IFRS adopters.

We re-estimate Equation (4) using a sample of mandatory adopters and voluntary adopters and report the results in Table A11 in the online Appendix. The results of regressions using INTEGRATE as the dependent variable show that Post has a positive and statistically significant coefficient, suggesting that voluntary adopters experience a significant increase in INTEGRATE after mandatory IFRS adoption. The interaction term Mandatory $\times$ Post is statistically insignificant, suggesting that mandatory adopters experienced an increase in INTEGRATE similar to that of voluntary adopters. In regressions using SPEED as the dependent variable, Post has an insignificant coefficient, indicating that voluntary adopters did not experience an increase in SPEED. The interaction term has a positive and statistically significant coefficient, suggesting that mandatory adopters experienced a larger increase in the speed of pricing global information, relative to voluntary adopters. In sum, the above evidence suggests that both mandatory and voluntary adopters benefit from mandatory IFRS adoption. However, the impact appears to be more substantial for mandatory adopter firms. ${ }^{22}$

Time effect

The results reported earlier are based on the sample period of 2003 to 2004 and 2006 to 2007. A concern is whether our results merely reflect a time trend that is unrelated to mandatory IFRS adoption. While the difference-in-difference design help address this concern, we conduct robustness tests to further alleviate the concern.

\footnotetext{
${ }^{22}$ This evidence also helps to address the concurrent institutional changes accompanying IFRS adoption in the adopting countries. To the extent these changes affect both voluntary and mandatory adopters in the same country, using voluntary adopters as a benchmark helps control for these concurrent changes.
} 
First, to allow for possible time trends in INTEGRATE and SPEED, we follow Landsman et al. (2012) and define a time-trend variable as year minus 2000. After controlling for this time-trend variable, we find no qualitative change in our results, reported in Table A12 in the online Appendix.

Second, we conduct placebo tests using pseudo-event years to evaluate whether similar results are obtained for these events as well. In particular, we choose an event year to replace 2005 and define the earlier (later) two years as the pre- (post-) period. For example, using the year 2003 as a pseudo-event year, we compare the years 2001 and 2002 against the years 2003 and 2004. If our findings are due to the 2005 IFRS adoption event, then we should not observe the same for these pseudo-event windows. The results from placebo tests are reported in Table A13 in the online Appendix. For the various pseudo-event years used, we fail to find a significant and positive coefficient on the variable of interest which is the interaction term Mandatory $\times$ Post. This finding further bolsters our evidence that mandatory IFRS adoption contributed to an increase in financial integration.

Alternative measurements of the financial integration variables: INTEGRATE and SPEED

As described earlier, our construction of the two financial integration measures, INTEGRATE and SPEED, involves the regression of a firm's stock returns on its local stock market index returns and global stock market index returns (see Equation (1)). The global stock market returns is based on the returns on the MSCI World Index. A criticism of the MSCI World Index is that it is heavily represented by a few large and developed countries (markets). To mitigate this concern, we use alternative global market indexes to re-estimate both INTEGRATE and SPEED. In contrast to the MSCI World Index which includes indexes from 23 developed countries, we use a more comprehensive global index - MSCI All Country World Index which consists of 23 developed markets and 21 developing markets. This index reduces the concentration of large developed markets in the global index. We also use the MSCI World Index after excluding the US from the index. This 
removes the influence of the US on the MSCI World Index which may otherwise capture US information rather than global information. We also use two Europe-centric indexes - the MSCI European Index and the STOXX European Index. This again mitigates the concern of overrepresentation of the US in the global market index. Furthermore, a large number of countries in these indices undertook mandatory adoption of IFRS. The results, reported in Table A14 in the online Appendix, show that our results are robust to the use of these alternative global market indices.

\section{Other robustness checks}

Our sample construction relies on the Compustat Global database which tends to cover larger firms in fewer countries in comparison to the Worldscope database. This may make our sample distribution across countries not comparable to those reported in prior studies that use the Worldscope database. To check if our results are sensitive to the database coverage, we reconstruct our sample and redo the main tests using data from the Worldscope and Datastream databases. The results are reported in Table A15 in the online Appendix. We still find significantly positive coefficients on the variable of interest, Mandatory $\times$ Post, when compared with non-adopters or voluntary adopters, for both financial integration measures.

In our sample, there are a small number of firms listed in a foreign country. For these crosslisted firms, it is not easy to define the country or local market of these firms. Also, the prices of a cross-listed stock and the underlying shares may not be congruent. To ensure that this unique group of firms does not affect our results, we redo our analyses after removing the firms that are cross-listed in a foreign country. Our results, reported in Table A16 in the online Appendix, remain unchanged.

Some firms have operations in foreign countries, which may make their stock prices more integrated in the global market. We conduct two robustness tests to control for foreign operations. First, we add variables in regressions controlling for foreign operations, including foreign assets, foreign sales, foreign merger and acquisition activities and cross-listing. Second, we exclude firms 
with foreign assets or foreign sales and redo our analysis. The results, reported in Table A17 in the online Appendix, show that our main results remain unchanged in both robustness tests.

Our main results compare mandatory adopters with non-adopters. Since adopting countries are mostly developed markets while non-adopting countries are mostly developing markets, there is a concern that some non-adopters may not be appropriate benchmarks. This concern is partially addressed when we use only non-adopters in the US as a benchmark. Furthermore, we use propensity score matching to select a sample of non-adopters that have similar size, are in the same industry, and have a similar level of enforcement strength as mandatory adopters. Specifically, we select matched firms from the non-adopting countries that are in the same industry, are from a country with the closest enforcement strength and have similar size (as measured by market capitalization). ${ }^{23}$ Firms from the US represent the largest portion of the matched sample, followed by firms in Japan. This suggests that a mandatory adopter in the UK is more likely to be matched to a non-adopter in the US, rather than a non-adopter in Argentina. ${ }^{24}$ We re-estimate Equation (4) using the matched sample. The results, reported in Table A18 in the online Appendix, are similar to those reported in the paper.

Our dependent variables in Equation (4), INTEGRATE and SPEED, are bounded by 0 and 1. While our results from OLS regression are robust and consistent, we also use Tobit model to reestimate Equation (4), and obtain similar results (reported in Table A19 in the online Appendix). In all regressions, we control for industry fixed effects and classify industry by one-digit standard industry classification codes. In a robustness test, we follow the classification of Fama-French 12 industries and redo the analysis. The results, reported in Table A20 in the online Appendix, remain unchanged.

\footnotetext{
${ }^{23}$ An advantage of this analysis is the parallel trends assumption underlying the difference-in-differences analysis is more defensible when the treatment and control firms more closely resemble one another.

${ }^{24}$ Examining the difference in law enforcement strength in the matched sample, we find that the mean of strength of law enforcement for the mandatory adopters is 1.381, and the mean for the non-adopters is 1.379 . The difference in the mean is not statistically significant ( $t$-stat. $=0.28$ ), so it appears that the matching does find mandatory adopters and voluntary adopters in countries with similar law enforcement strength.
} 


\section{Conclusions}

A large number of studies in international finance have documented evidence that greater financial integration helps reduce the cost of capital and increase corporate investment and economic growth (Henry 2000a, 2000b; Bekaert and Harvey 2001). However, significant barriers that impede financial integration still exist and the global market is still far from full integration. One barrier is information frictions that discourage foreign investment and hamper capital mobility. In 2005, a number of countries adopted IFRS with the expectation that a uniform set of accounting standards to achieve accounting harmonization would make accounting numbers more comparable across markets and thus facilitate financial integration by reducing information frictions. We empirically evaluate this question by examining the effect of mandatory IFRS adoption on financial integration. We hypothesize that accounting standards harmonization facilitates financial integration by improving accounting comparability and reducing information costs. Following the concept of financial integration proposed by the extant literature, we construct empirical measures to capture two related but distinct aspects of financial integration. The first measure is the extent to which local stock returns can be explained by global factors, with a larger extent indicating greater integration. The second measure is the speed at which global information is incorporated into local stock returns, with a faster speed indicating greater integration. Our empirical tests use a difference-in-difference design and compare mandatory adopters with non-adopters and voluntary adopters.

Consistent with our hypotheses, we find that mandatory adopters experience a greater improvement in financial integration after adopting IFRS, relative to non-adopters. Specifically, we find that IFRS adoption positively impacts the proportion of stock return variation explained by global factors. IFRS adoption also increases the speed with which global news is incorporated into a firm's stock prices. Further, we find these effects of IFRS are more pronounced in countries with larger differences between IFRS and local GAAP, or in countries that experience a larger improvement in 
accounting comparability. The evidence suggests that IFRS adoption facilitates financial integration through improved accounting comparability that enhances cross-border information flow. We also find the impact of IFRS on financial integration to be more pronounced when it is accompanied by a greater increase in foreign ownership. This evidence suggests that increase in foreign investment and capital mobility is likely to be another channel through which IFRS adoption can facilitate financial integration.

Our study contributes to the literature on financial integration by showing that adopting a uniform set of accounting standards (i.e. accounting harmonization) improves financial integration by reducing information frictions. Our results shed light on regulatory efforts around the world to improve financial integration by removing various barriers that hinder full integration. In particular, our study supports the regulators' expectation that IFRS adoption helps improve financial integration.

Our results also contribute to the growing literature on the effect of IFRS adoption. Prior studies have documented that IFRS adoption has an impact on foreign ownership of local stocks. Our study takes one step further and shows that IFRS facilitates financial integration. Other studies find an impact of IFRS on the cost of capital and explain the lower cost of capital following IFRS adoption by the reduction of information asymmetry or the improvement in information quality. Our evidence suggests that another potential explanation for this finding is the improvement in risk sharing due to increased financial integration, as documented in the international finance literature. 


\section{References}

Abiad, A., E. Detragiache, and T. Tressel. 2008. A new database of financial reform. Working paper, International Monetary Fund.

Ahmed, A.S., M. Neel, and D. Wang. 2013. Does mandatory adoption of IFRS improve accounting quality? Preliminary evidence. Contemporary Accounting Research 30 (4): 1344-1372.

Amiram, D. 2012. Financial information globalization and foreign investment decisions. Journal of International Accounting Research 11 (2): 57-81.

Bae, K., A. Ozoguz, H. Tan, and T. Wirjanto. 2012. Do foreigners facilitate information transmission in emerging markets? Journal of Financial Economics 105: 209-227.

Bae, K., H. Tan, and M. Welker. 2008. International GAAP differences: The impact on foreign analysts. Accounting Review 83: 593-628.

Barth, M., W. R. Landsman, and M. Lang. 2008. International Accounting Standards and accounting quality. Journal of Accounting Research 46: 467-498.

Bekaert, G. 1995. Market integration and investment barriers in emerging equity markets. World Bank Economic Review 9: 75-107.

Bekaert, G., and C. R. Harvey. 1995. Time-varying world market integration. Journal of Finance 50: 403-44.

Bekaert, G., and C. R. Harvey. 2001. Economic growth and financial liberalization. Research Summary in the NBER Reporter, Spring 2001: 8-11.

Bekaert, G., C. R. Harvey, and R. Lumsdaine. 2002. Dating the integration of world capital markets. Journal of Financial Economics 65: 203-249.

Bekaert, G., C. R. Harvey, and C. T. Lundblad. 2003. Equity market liberalization in emerging markets. Journal of Financial Research 26: 275-299.

Bekaert, G., C. R. Harvey, C. Lundblad, and S. Siegel. 2011. What segments equity markets? Review of Financial Studies 24: 3841-3890.

Bekaert, G., C. R. Harvey, C. Lundblad, and S. Siegel. 2013. The European Union, the Euro, and equity market integration. Journal of Financial Economics 109: 583-603.

Beneish, M., B. Miller, and T. Yohn. 2009. The effect of IFRS adoption on cross-border investment in equity and debt markets. Working paper, Indiana University.

Brown, P., J. Preiato, and A. Tarca. 2014. Measuring country differences in enforcement of accounting standards: An audit and enforcement proxy. Journal of Business Finance and Accounting 41: 1-52.

Bruggemann, U., H. Daske, C. Homburg, and P. Pope. 2009. How do individual investors react to global IFRS adoption? Working paper, Lancaster University, University of Mannheim, and University of Cologne.

Byard, D., Y. Li, and Y. Yu. 2011. The effect of mandatory IFRS adoption on financial analysts' information environment. Journal of Accounting Research 49: 69-96.

Callen, J., M. Khan, and H. Lu. 2013. Accounting quality, stock price delay and future stock returns. Contemporary Accounting Research 30 (1): 269-295.

Chari, A., and P. B. Henry. 2004. Risk sharing and asset prices: Evidence from a natural experiment. Journal of Finance 59 (3): 1295-1324.

Christensen, H. B., L. Hail, and C. Leuz. 2013. Mandatory IFRS reporting and changes in enforcement. Journal of Accounting and Economics 56: 147-177.

Chuhan, P. 1992. Sources of portfolio investment in emerging markets. World Bank Working Paper, International Department of Economics, Washington DC. 
Covrig, V., M. DeFond, and M. Hung. 2007. Home bias, foreign mutual fund holdings, and the voluntary adoption of International Accounting Standards. Journal of Accounting Research 45: 41-70.

Daske, H., L. Hail, C. Leuz, and R. Verdi. 2008. Mandatory IFRS reporting around the world: Early evidence on the economic consequences. Journal of Accounting Research 46: 1085-1142.

Daske, H., L. Hail, C. Leuz, and R. Verdi. 2013. Adopting a label: Heterogeneity in the economic consequences around IAS/IFRS adoptions. Journal of Accounting Research 51 (3): 495-547.

DeFond, M., X. Hu, M. Hung, and S. Li. 2011. The impact of mandatory IFRS adoption on foreign mutual fund ownership: The role of comparability. Journal of Accounting and Economics 51: 240-258.

DeFond, M., M. Hung, S. Li, and Y. Li. 2015. Does mandatory IFRS adoption affect crash risk? Accounting Review 90: 265-300.

De Franco, G., S. P. Kothari, and R. S. Verdi. 2011. The benefits of financial statement comparability. Journal of Accounting Research 49 (4): 895-931.

De George, E., X. Li, and L. Shivakumar. 2016. A review of the IFRS adoption literature. Review of Accounting Studies 21 (3): 898-1004.

Dittmar, A., J. Mahrt-Smith and H. Servaes. 2003. International corporate governance and corporate cash holdings. Journal of Financial and Quantitative Analysis 38: 111-133.

Errunza V., and E. Losq. 1985. International asset pricing under mild segmentation: Theory and test. Journal of Finance 40: 105-24.

Errunza, V., E. Losq, and P. Padmanabhan. 1992. Tests of integration, mild segmentation and segmentation hypotheses. Journal of Banking and Finance 16: 949-972.

Florou, A., and P. Pope. 2012. Mandatory IFRS adoption and institutional investment decisions. Accounting Review 87 (6): 1993-2025.

Francis, J., S. Huang, and I. Khurana. 2012, The role of international GAAP in cross-border mergers and acquisitions. Working paper, University of Missouri.

Giannetti, M., L. Guiso, T. Jappelli, M. Padula, and M. Pagano. 2002. Financial market integration, corporate financing and economic growth. European Commission Economic Papers No. 179. Available at http://ec.europa.eu/economy finance/publications/pages/publication1660 en.pdf.

Gordon, L., M. Loeb, and W. Zhu. 2012, The impact of IFRS adoption on foreign direct investment. Journal of Accounting and Public Policy 31 (4): 374-398.

Gultekin, M. N., N. B. Gultekin, and A. Penati. 1989. Capital controls and international capital market segmentation: The evidence from the Japanese and American stock markets. Journal of Finance 44 (4): 849-869.

Henry, P. B. 2000a. Stock market liberalization, economic reform, and emerging market equity prices. Journal of Finance 55 (2): 529-564.

Henry, P. B. 2000b. Do stock market liberalizations cause investment booms? Journal of Financial Economics 58: 301-334.

Henry, P. B. 2003. Capital-account liberalization, the cost of capital, and economic growth. American Economic Review 93: 91-96.

Horton, J., G. Serafeim, and I. Serafeim. 2013. Does mandatory IFRS adoption improve the information environment? Contemporary Accounting Research 30 (1): 388-423.

Hou, K., and T. J. Moskowitz. 2005. Market frictions, price delay, and the cross section of expected returns. Review of Financial Studies 18: 981-1020.

Isidro, H., D. Nanda, and P. Wysocki. 2016. Financial reporting differences around the world: What matters? Working paper, University of Miami. 
Kalemli-Ozcan, S., S. Manganelli, E. Papaioannou, and J. L. Peydró. 2008. Financial integration and risk sharing: The role of the monetary union. Working paper, University of Houston and NBER.

Karolyi, G. A. 2003. Does international financial contagion really exist? International Finance 6 (2): 179-199.

Kaufmann, D., A. Kraay, and M. Mastruzzi. 2007. Governance matters VI: Aggregate and individual governance indicators 1996-2006. The World Bank, Washington, DC.

Kim, Y., and S. Li. 2011. The externality effect of accounting standards convergence: Evidence from cross-border information transfers around EU mandatory IFRS adoption. Working paper, Santa Clara University.

Kim, J.-B., and H. Shi. 2012. IFRS reporting, firm-specific information flows, and institutional environments: International evidence. Review of Accounting Studies 17: 474-517.

Korajczyk, R. A., and C. J. Vialet. 1989. An empirical investigation of international asset pricing. Review of Financial Studies 2 (4): 553-585.

Lai, C., Y. Li, Y. Shan, and S. Taylor. 2013. Costs of mandatory international financial reporting standards: Evidence of reduced accrual reliability. Australian Journal of Management 38: 491-521.

Landsman, W., E. Maydew, and J. Thornock. 2012. The information content of annual earnings announcements and mandatory adoption of IFRS. Journal of Accounting and Economics 53 (1-2): 34-54.

Lantto, A.-M., and P. Sahlstrom. 2009. Impact of international financial reporting standard adoption on key financial ratios. Accounting and Finance 49: 341-361.

Lewis, K. K. 2011. Global asset pricing. Annual Review of Financial Economics 3: 435-466.

Li, S. 2010. Does mandatory adoption of International Financial Reporting Standards in the European Union reduce the cost of equity capital? Accounting Review 85: 607-636.

Louis, H., and O. Urcan. 2014. The effect of IFRS on cross-border acquisitions. Working paper, Pennsylvania State University.

Nobes, C. W., and S. A. Zeff. 2016. Have Canada, Japan and Switzerland adopted IFRS? Australian Accounting Review 26: 284-290.

Obstfeld, M., and A. Taylor. 2004. Global capital markets: integration, crisis, and growth. Cambridge University Press.

Pownall G., M. Vulcheva, and X. Wang. 2014. The ability of global stock exchange mechanisms to mitigate home bias: Evidence from Euronext. Management Science 60: 1655-1676.

Pownall, G., and M. Wieczynska. 2017. Deviations from the Mandatory Adoption of IFRS in the European Union: Implementation, Enforcement, Incentives, and Compliance. Working paper, available at SSRN: https://ssrn.com/abstract=1919805.

Pukthuanthong, K., and R. Roll. 2009. Global market integration: An alternative measure and its application. Journal of Financial Economics 94: 214-232.Stulz, R. M. 1981. A model of international asset pricing. Journal of Financial Economics 9: 383-406.

Stulz, R. M. 1981. A model of international asset pricing. Journal of Financial Economics 9: 383-406. 
Stulz, R. M. 1999. Globalization, corporate finance and the cost of capital. Journal of Applied Corporate Finance 12 (3): 8-25.

Stulz, R. M. 2005. The limits of financial globalization. Journal of Finance 60: 1595-1638.

Tan, H., S. Wang, and M. Welker. 2011. Foreign analysts following and forecast accuracy around mandatory IFRS adoptions. Journal of Accounting Research 49 (5): 1307-1357.

Wang, C. 2014. Accounting standards harmonization and financial statement comparability: Evidence from transnational information transfer. Journal of Accounting Research 52: 955-992.

Yip, R., and D. Young. 2012. Does mandatory IFRS adoption improve information comparability? Accounting Review 87 (5): 1767-1789.

Yu, G., and A. S. Wahid. 2014. Accounting standards and international portfolio holdings. Accounting Review 89 (5): 1895-1930. 
Appendix: Variable Definitions

\begin{tabular}{|c|c|c|}
\hline Variables & Definition & Source \\
\hline \multicolumn{3}{|c|}{ Dependent variables } \\
\hline INTEGRATE & $\begin{array}{l}\text { A measure of financial integration based on the ratio of the } \\
\text { proportion of stock return variation explained by current and lagged } \\
\text { global market returns to the proportion of return variation that can } \\
\text { be explained by current and lagged global and local market returns. }\end{array}$ & $\begin{array}{l}\text { Constructed from } \\
\text { stock returns data } \\
\text { in Compustat and } \\
\text { market index data } \\
\text { from Datastream }\end{array}$ \\
\hline SPEED & $\begin{array}{l}\text { A measure of speed at which stock prices respond to global market } \\
\text { information, based on the ratio of the proportion of stock return } \\
\text { variation explained by current global market returns and current and } \\
\text { lagged local market returns to the proportion of return variation that } \\
\text { can be explained by current and lagged global and local market } \\
\text { returns. }\end{array}$ & $\begin{array}{l}\text { Constructed from } \\
\text { stock returns data } \\
\text { in Compustat and } \\
\text { market index data } \\
\text { from Datastream }\end{array}$ \\
\hline
\end{tabular}

\section{Variables of interest}

Mandatory An indicator variable equal to 1 for mandatory adopters, and 0 otherwise. Mandatory adopters are firms located in adopting countries that mandated International Financial Reporting Standards in 2005. Mandatory adopters used local GAAP before 2005 and switched to IFRS after 2005 when the country mandated IFRS adoption.

Post An indicator variable equal to 1 for firm-year observations after 2005, and 0 otherwise.

\section{Control variables}

Size

Turnover

Volatility

TradingDay

Loss

AnalystCover

IndexStock

$A D R$

GDP

MktCap_GDP

GDPGrowth

Trade

\section{Partition variables}

GAAP difference

Accounting comparability
Natural log of a firm's market capitalization.

Average weekly trading volume divided by total number of shares outstanding.

Standard deviation of weekly stock returns in a year.

Natural log of the number of days in which a stock has positive trading volume in a year.

An indicator variable equal to 1 if a firm reports a negative operating income, and 0 otherwise.

An indicator variable equal to 1 if a firm received analyst coverage, and 0 otherwise.

An indicator variable equal to 1 if a firm is a member of MSCI country index, and 0 otherwise.

An indicator variable equal to 1 if a firm has an American depositary receipt (ADR), and 0 otherwise.

Natural log of a country's Gross Domestic Product.

The ratio of a country's total market capitalization to its Gross Domestic Product.

The annual growth rate (in percentage) of a country's Gross Domestic Product.

The sum of a country's imports and exports, deflated by GDP.

The number of major differences between local GAAP and IFRS, as compiled by Bae et al. (2008).

the average absolute value of the difference between a firm's expected earnings using accounting function in its own country and
Constructed from accounting standards data in Compustat

Compustat

Compustat

Compustat

Compustat

Compustat

IBES

Datastream

Datastream

World Bank

World Bank

World Bank

World Bank

Bae et al. (2008)

Constructed from data in Compustat 
the expected earnings using accounting functions in other countries, following De Franco et al. (2009) and Yip and Young (2012). 
TABLE 1 Sample distribution by countries

This table reports sample distribution by country. Mandatory adopters are firms that switched from local GAAP to IFRS in 2005 or 2006 and are located in countries that mandated IFRS adoption in 2005. Non-adopters are firms that followed local GAAP from 2003 to 2007 and are located in countries that did not mandate IFRS in our sample period.

\begin{tabular}{|c|c|c|c|c|c|}
\hline \multicolumn{3}{|c|}{ Mandatory adopters } & \multicolumn{3}{|c|}{ Non-Adopters } \\
\hline $\begin{array}{l}\text { Adopting } \\
\text { Countries }\end{array}$ & $\begin{array}{l}\text { Unique } \\
\text { firms }\end{array}$ & $\begin{array}{l}\text { Firm-years } \\
\text { (2003, 2004; } \\
\text { 2006, 2007) }\end{array}$ & $\begin{array}{l}\text { Non-Adopting } \\
\text { Countries }\end{array}$ & $\begin{array}{l}\text { Unique } \\
\text { firms }\end{array}$ & $\begin{array}{c}\text { Firm-years } \\
(2003,2004 ; \\
\text { 2006, 2007) }\end{array}$ \\
\hline Australia & 49 & 196 & Argentina & 34 & 136 \\
\hline Austria & 9 & 36 & Brazil & 91 & 364 \\
\hline Belgium & 58 & 232 & Canada & 150 & 600 \\
\hline Denmark & 78 & 312 & China & 293 & 1,172 \\
\hline Finland & 90 & 360 & India & 389 & 1,556 \\
\hline France & 353 & 1,412 & Indonesia & 138 & 552 \\
\hline Germany & 145 & 580 & Israel & 27 & 108 \\
\hline Greece & 74 & 296 & Japan & 3,113 & 12,452 \\
\hline Ireland & 27 & 108 & Malaysia & 597 & 2,388 \\
\hline Italy & 185 & 740 & Mexico & 37 & 148 \\
\hline Netherlands & 97 & 388 & New Zealand & 49 & 196 \\
\hline Norway & 85 & 340 & Pakistan & 58 & 232 \\
\hline Portugal & 30 & 120 & Peru & 6 & 24 \\
\hline South Africa & 152 & 608 & South Korea & 899 & 3,596 \\
\hline Spain & 79 & 316 & Thailand & 218 & 872 \\
\hline Sweden & 192 & 768 & Turkey & 19 & 76 \\
\hline United Kindom & 584 & 2,336 & USA & 4,452 & 17,808 \\
\hline Total & 2,287 & 9,148 & Total & 10,570 & 42,280 \\
\hline
\end{tabular}




\section{TABLE 2 Descriptive statistics}

This table reports descriptive statistics for sample firms. This table reports sample distribution by country. Mandatory adopters are firms that switched from local GAAP to IFRS in 2005 or 2006 and are located in countries that mandated IFRS adoption in 2005. Non-adopters are firms that followed local GAAP from 2003 to 2007 and are located in countries that did not mandate IFRS in our sample period. Refer to the Appendix for the definitions of all variables.

Panel A: Descriptive statistics in the pre-IFRS adoption period (2003 and 2004)

\begin{tabular}{lcccccc}
\hline & \multicolumn{2}{c}{ Mandatory Adopters $(\mathrm{N}=4,574)$} & \multicolumn{3}{c}{ Non-Adopters (N=21,140) } \\
& Mean & Median & Std & Mean & Median & Std \\
\hline INTEGRATE & 0.591 & 0.616 & 0.225 & 0.538 & 0.539 & 0.239 \\
SPEED & 0.741 & 0.787 & 0.200 & 0.770 & 0.823 & 0.188 \\
Size & 19.073 & 18.917 & 2.095 & 20.946 & 21.268 & 3.270 \\
Turnover & 0.009 & 0.006 & 0.011 & 0.023 & 0.008 & 0.042 \\
Volatility & 0.053 & 0.049 & 0.023 & 0.074 & 0.063 & 0.043 \\
TradingDay & 5.301 & 5.505 & 0.485 & 5.299 & 5.493 & 0.534 \\
Loss & 0.207 & 0.000 & 0.406 & 0.257 & 0.000 & 0.437 \\
AnalystCover & 0.515 & 1.000 & 0.500 & 0.417 & 0.000 & 0.493 \\
IndexStock & 0.484 & 0.000 & 0.500 & 0.460 & 0.000 & 0.498 \\
ADR & 0.040 & 0.000 & 0.195 & 0.011 & 0.000 & 0.106 \\
GDP & 27.473 & 28.182 & 1.006 & 28.839 & 29.158 & 1.474 \\
MktCap_GDP & 0.936 & 0.901 & 0.403 & 0.994 & 0.850 & 0.374 \\
GDPGrowth & 2.494 & 2.949 & 1.424 & 3.533 & 2.744 & 2.003 \\
Trade & 0.651 & 0.538 & 0.234 & 0.435 & 0.247 & 0.444 \\
\hline
\end{tabular}

Panel B: Descriptive statistics in the post-IFRS adoption period (2006 and 2007)

\begin{tabular}{lcccccc}
\hline & \multicolumn{2}{c}{ Mandatory Adopters (N=4,574) } & \multicolumn{3}{c}{ Non-Adopters (N=21,140) } \\
& Mean & Median & Std & Mean & Median & Std \\
\hline INTEGRATE & 0.652 & 0.687 & 0.213 & 0.555 & 0.559 & 0.226 \\
SPEED & 0.777 & 0.835 & 0.189 & 0.787 & 0.841 & 0.182 \\
Size & 19.798 & 19.664 & 2.128 & 21.540 & 21.868 & 3.309 \\
Turnover & 0.014 & 0.009 & 0.017 & 0.029 & 0.014 & 0.044 \\
Volatility & 0.041 & 0.037 & 0.017 & 0.060 & 0.051 & 0.035 \\
TradingDay & 5.428 & 5.529 & 0.325 & 5.407 & 5.509 & 0.363 \\
Loss & 0.129 & 0.000 & 0.336 & 0.215 & 0.000 & 0.411 \\
AnalystCover & 0.627 & 1.000 & 0.484 & 0.440 & 0.000 & 0.496 \\
IndexStock & 0.484 & 0.000 & 0.500 & 0.460 & 0.000 & 0.498 \\
ADR & 0.036 & 0.000 & 0.185 & 0.011 & 0.000 & 0.102 \\
GDP & 27.734 & 28.386 & 0.978 & 29.032 & 29.108 & 1.375 \\
MktCap_GDP & 1.229 & 1.222 & 0.538 & 1.230 & 1.425 & 0.288 \\
GDPGrowth & 3.250 & 3.269 & 1.051 & 3.503 & 2.363 & 2.500
\end{tabular}


This article is protected by copyright. All rights reserved. 


\section{TABLE 3 Correlation coefficients}

This table reports the correlation coefficients between the variables used in multivariate analyses. Pearson correlation coefficients are reported below the diagonal while Spearman correlation coefficients are reported above the diagonal. All the coefficients are statistically significant at the $10 \%$ level or better, except those marked with ^.

\begin{tabular}{|c|c|c|c|c|c|c|c|c|c|c|c|c|c|c|}
\hline & $(1)$ & $(2)$ & (3) & $(4)$ & $(5)$ & $(6)$ & $(7)$ & $(8)$ & (9) & $(10)$ & $(11)$ & $(12)$ & $(13)$ & $(14)$ \\
\hline (1)INTEGRATE & 1 & 0.257 & -0.054 & 0.193 & -0.057 & 0.343 & -0.031 & 0.207 & 0.149 & 0.048 & 0.231 & 0.179 & -0.103 & -0.088 \\
\hline (2)SPEED & 0.273 & 1 & 0.314 & 0.209 & -0.143 & 0.244 & -0.162 & 0.211 & 0.275 & 0.061 & -0.021 & -0.026 & 0.011 & 0.025 \\
\hline (3)Size & -0.035 & 0.309 & 1 & 0.199 & -0.322 & 0.117 & -0.375 & 0.205 & 0.386 & 0.070 & -0.172 & -0.376 & 0.009 & 0.024 \\
\hline (4)Turnover & 0.075 & 0.092 & 0.152 & 1 & 0.209 & 0.475 & 0.028 & 0.248 & 0.331 & 0.032 & 0.198 & 0.151 & 0.060 & $0.005^{\wedge}$ \\
\hline (5)Volatility & -0.049 & -0.177 & -0.450 & 0.181 & 1 & -0.195 & 0.454 & -0.223 & -0.211 & -0.032 & 0.149 & 0.031 & 0.045 & -0.205 \\
\hline (6)TradingDay & 0.107 & 0.195 & 0.240 & 0.148 & -0.169 & 1 & -0.132 & 0.447 & 0.415 & 0.091 & 0.255 & 0.201 & -0.076 & -0.068 \\
\hline (7)Loss & -0.032 & -0.162 & -0.389 & 0.089 & 0.500 & -0.105 & 1 & -0.194 & -0.213 & -0.023 & 0.143 & 0.121 & -0.019 & -0.093 \\
\hline (8)AnalystCover & 0.206 & 0.204 & 0.228 & 0.033 & -0.249 & 0.258 & -0.194 & 1 & 0.434 & 0.078 & 0.095 & 0.058 & -0.107 & -0.051 \\
\hline (9)IndexStock & 0.149 & 0.265 & 0.399 & 0.101 & -0.235 & 0.265 & -0.213 & 0.434 & 1 & 0.113 & 0.041 & $-0.001^{\wedge}$ & $-0.005^{\wedge}$ & -0.059 \\
\hline (10)ADR & 0.047 & 0.049 & 0.076 & -0.007 & -0.035 & 0.036 & -0.023 & 0.078 & 0.113 & 1 & -0.047 & -0.022 & 0.012 & 0.038 \\
\hline (11)GDP & 0.227 & -0.030 & -0.149 & 0.041 & 0.225 & 0.024 & 0.128 & 0.085 & 0.043 & -0.043 & 1 & 0.434 & -0.426 & -0.714 \\
\hline (12)MktCap_GDP & 0.181 & -0.025 & -0.340 & $0.007^{\wedge}$ & 0.117 & 0.039 & 0.109 & 0.061 & $0.007^{\wedge}$ & -0.020 & 0.310 & 1 & 0.085 & -0.076 \\
\hline (13)GDPGrowth & -0.177 & 0.015 & 0.076 & 0.053 & -0.027 & 0.027 & -0.045 & -0.134 & 0.029 & $-0.002^{\wedge}$ & -0.447 & 0.018 & 1 & 0.416 \\
\hline (14)Trade & -0.135 & 0.013 & -0.077 & -0.017 & -0.167 & -0.010 & -0.051 & -0.064 & -0.085 & 0.010 & -0.766 & 0.042 & 0.408 & 1 \\
\hline
\end{tabular}


TABLE 4 Multivariate analysis of mandatory adopters and non-adopters

This table presents a multivariate analysis of financial integration measures between mandatory adopters and non-adopters of IFRS. This table reports sample distribution by country. Mandatory adopters are firms that switched from local GAAP to IFRS in 2005 or 2006 and are located in countries that mandated IFRS adoption in 2005. Non-adopters are firms that followed local GAAP from 2003 to 2007 and are located in countries that did not mandate IFRS in our sample period. Refer to the Appendix for the definitions of all variables. Reported in parentheses are the $p$-values based on two-tailed tests and firm-cluster adjusted standard errors. ${ }^{* * *}$, ${ }^{* *}$, and * indicate significance at the $1 \%, 5 \%$, and $10 \%$ level, respectively.

\begin{tabular}{|c|c|c|c|c|c|c|}
\hline & \multicolumn{3}{|c|}{ DEP = INTEGRATE } & \multicolumn{3}{|c|}{ DEP $=S P E E D$} \\
\hline & (1) & $(2)$ & (3) & (4) & (5) & $(6)$ \\
\hline Mandatory & $\begin{array}{c}0.050^{* * *} \\
(0.000)\end{array}$ & & $\begin{array}{c}0.111^{* * *} \\
(0.000)\end{array}$ & $\begin{array}{c}-0.033^{* * *} \\
(0.000)\end{array}$ & & $\begin{array}{c}-0.014^{* * *} \\
(0.000)\end{array}$ \\
\hline Post & $\begin{array}{c}0.015^{* * *} \\
(0.000)\end{array}$ & $\begin{array}{c}-0.023^{* * *} \\
(0.000)\end{array}$ & $\begin{array}{c}-0.020 * * * \\
(0.000)\end{array}$ & $\begin{array}{c}0.015^{* * *} \\
(0.000)\end{array}$ & $\begin{array}{c}0.029 * * * \\
(0.000)\end{array}$ & $\begin{array}{c}-0.005^{* * *} \\
(0.003)\end{array}$ \\
\hline Mandatory $\times$ Post & $\begin{array}{c}0.047^{* * *} \\
(0.000)\end{array}$ & $\begin{array}{c}0.032^{* * *} \\
(0.000)\end{array}$ & $\begin{array}{c}0.031^{* * *} \\
(0.000)\end{array}$ & $\begin{array}{c}0.023^{* * *} \\
(0.000)\end{array}$ & $\begin{array}{c}0.017 * * * \\
(0.000)\end{array}$ & $\begin{array}{c}0.016^{* * *} \\
(0.000)\end{array}$ \\
\hline Firm-level controls & & & & & & \\
\hline Size & & $\begin{array}{c}0.016^{* * *} \\
(0.000)\end{array}$ & $\begin{array}{c}0.001^{* *} \\
(0.033)\end{array}$ & & $\begin{array}{c}0.021^{* * *} \\
(0.000)\end{array}$ & $\begin{array}{c}0.013^{* * *} \\
(0.000)\end{array}$ \\
\hline Turnover & & $\begin{array}{c}0.263^{* * *} \\
(0.000)\end{array}$ & $\begin{array}{c}0.494^{* * *} \\
(0.000)\end{array}$ & & $\begin{array}{c}0.269 * * * \\
(0.000)\end{array}$ & $\begin{array}{c}0.189 * * * \\
(0.000)\end{array}$ \\
\hline Volatility & & $\begin{array}{c}-0.288^{* * *} \\
(0.000)\end{array}$ & $\begin{array}{c}-0.252 * * * \\
(0.000)\end{array}$ & & $\begin{array}{c}0.077^{* *} \\
(0.021)\end{array}$ & $\begin{array}{c}-0.058^{*} \\
(0.074)\end{array}$ \\
\hline TradingDay & & $\begin{array}{c}0.009 * * * \\
(0.000)\end{array}$ & $\begin{array}{c}0.015^{* * *} \\
(0.000)\end{array}$ & & $\begin{array}{c}0.029 * * * \\
(0.000)\end{array}$ & $\begin{array}{c}0.034 * * * \\
(0.000)\end{array}$ \\
\hline Loss & & $\begin{array}{c}-0.011 * * * \\
(0.000)\end{array}$ & $\begin{array}{c}-0.011 * * * \\
(0.000)\end{array}$ & & $\begin{array}{c}-0.009 * * * \\
(0.000)\end{array}$ & $\begin{array}{c}-0.013^{* * *} \\
(0.000)\end{array}$ \\
\hline AnalystCover & & $\begin{array}{c}0.011^{* * *} \\
(0.000)\end{array}$ & $\begin{array}{c}0.038 * * * \\
(0.000)\end{array}$ & & $\begin{array}{c}0.016^{* * *} \\
(0.000)\end{array}$ & $\begin{array}{c}0.025^{* * *} \\
(0.000)\end{array}$ \\
\hline IndexStock & & $\begin{array}{c}0.013^{* * *} \\
(0.000)\end{array}$ & $\begin{array}{c}0.033^{* * *} \\
(0.000)\end{array}$ & & $\begin{array}{c}0.028 * * * \\
(0.000)\end{array}$ & $\begin{array}{c}0.041^{* * *} \\
(0.000)\end{array}$ \\
\hline$A D R$ & & $\begin{array}{l}-0.006 \\
(0.474)\end{array}$ & $\begin{array}{c}0.052 * * * \\
(0.000)\end{array}$ & & $\begin{array}{c}0.001 \\
(0.841)\end{array}$ & $\begin{array}{c}0.014^{* *} \\
(0.027)\end{array}$ \\
\hline Country-level controls & & & & & & \\
\hline$G D P$ & & $\begin{array}{c}0.062 * * * \\
(0.000)\end{array}$ & $\begin{array}{c}0.050^{* * *} \\
(0.000)\end{array}$ & & $\begin{array}{c}-0.090 * * * \\
(0.000)\end{array}$ & $\begin{array}{c}0.002 \\
(0.230)\end{array}$ \\
\hline MktCap_GDP & & $\begin{array}{c}0.032 * * * \\
(0.001)\end{array}$ & $\begin{array}{c}0.076^{* * *} \\
(0.000)\end{array}$ & & $\begin{array}{c}-0.032 * * * \\
(0.000)\end{array}$ & $\begin{array}{c}0.019 * * * \\
(0.000)\end{array}$ \\
\hline GDPGrowth & & $\begin{array}{c}-0.005^{* * *} \\
(0.005)\end{array}$ & $\begin{array}{c}-0.005^{* * *} \\
(0.000)\end{array}$ & & $\begin{array}{c}0.010^{* * *} \\
(0.000)\end{array}$ & $\begin{array}{c}-0.002^{* * *} \\
(0.000)\end{array}$ \\
\hline Trade & & $\begin{array}{c}0.099 * * * \\
(0.006)\end{array}$ & $\begin{array}{c}0.037 * * * \\
(0.000)\end{array}$ & & $\begin{array}{c}-0.080 * * * \\
(0.009)\end{array}$ & $\begin{array}{c}0.028^{* * *} \\
(0.000)\end{array}$ \\
\hline
\end{tabular}




\begin{tabular}{|c|c|c|c|c|c|c|}
\hline $\begin{array}{l}\text { Industry Fixed Effects } \\
\text { Country Fixed Effects }\end{array}$ & $\begin{array}{l}\text { YES } \\
\text { NO }\end{array}$ & $\begin{array}{l}\text { YES } \\
\text { YES }\end{array}$ & $\begin{array}{l}\text { YES } \\
\text { NO }\end{array}$ & $\begin{array}{l}\text { YES } \\
\text { NO }\end{array}$ & $\begin{array}{l}\text { YES } \\
\text { YES }\end{array}$ & $\begin{array}{l}\text { YES } \\
\text { NO }\end{array}$ \\
\hline $\mathrm{N}$ & 51,428 & 51,428 & 51,428 & 51,428 & 51,428 & 51,428 \\
\hline Adjusted $\mathrm{R}^{2}$ & 0.0249 & 0.2195 & 0.1601 & 0.0137 & 0.1627 & 0.1426 \\
\hline
\end{tabular}




\section{TABLE 5 Effect of GAAP differences}

This table presents the analysis of the effect of institutional factors on the changes in financial integration measures for mandatory adopters of IFRS. This table reports sample distribution by country. Mandatory adopters are firms that switched from local GAAP to IFRS in 2005 or 2006 and are located in countries that mandated IFRS adoption in 2005. We partition the sample into two groups based on the number of major differences between local GAAP and IFRS, as compiled by Bae et al. (2008). The Large (Small) group includes mandatory adopters located in countries with larger (smaller) GAAP differences than the median of the sample. Refer to the Appendix for the definitions of all variables. Reported in parentheses are the $p$-values based on twotailed tests and firm-cluster adjusted standard errors. ***, **, and * indicate significance at the $1 \%, 5 \%$ and $10 \%$ levels, respectively.

\begin{tabular}{|c|c|c|c|c|}
\hline & \multicolumn{2}{|c|}{ DEP = INTEGRATE } & \multicolumn{2}{|c|}{ DEP = SPEED } \\
\hline & $\begin{array}{c}\text { Large } \\
(1)\end{array}$ & $\begin{array}{c}\text { Small } \\
(2)\end{array}$ & $\begin{array}{c}\text { Large } \\
\text { (3) }\end{array}$ & $\begin{array}{c}\text { Small } \\
(4)\end{array}$ \\
\hline Post $\left(\beta_{1}\right)$ & $\begin{array}{c}0.040^{* * *} \\
(0.000)\end{array}$ & $\begin{array}{c}0.001 \\
(0.884)\end{array}$ & $\begin{array}{c}0.025^{* * *} \\
(0.002)\end{array}$ & $\begin{array}{c}0.011 \\
(0.149)\end{array}$ \\
\hline \multicolumn{5}{|l|}{ Firm-level controls } \\
\hline Size & $\begin{array}{c}0.014^{* * *} \\
(0.000)\end{array}$ & $\begin{array}{c}0.017 * * * \\
(0.000)\end{array}$ & $\begin{array}{c}0.025^{* * *} \\
(0.000)\end{array}$ & $\begin{array}{c}0.032 * * * \\
(0.000)\end{array}$ \\
\hline Turnover & $\begin{array}{c}1.668 * * * \\
(0.000)\end{array}$ & $\begin{array}{c}0.607 * * \\
(0.011)\end{array}$ & $\begin{array}{c}0.953^{* * *} \\
(0.002)\end{array}$ & $\begin{array}{c}0.210 \\
(0.534)\end{array}$ \\
\hline Volatility & $\begin{array}{c}0.372 * \\
(0.065)\end{array}$ & $\begin{array}{c}0.069 \\
(0.746)\end{array}$ & $\begin{array}{c}0.761^{* * *} \\
(0.000)\end{array}$ & $\begin{array}{c}0.385 * * \\
(0.044)\end{array}$ \\
\hline TradingDay & $\begin{array}{c}0.021^{* * *} \\
(0.007)\end{array}$ & $\begin{array}{c}0.037 * * * \\
(0.000)\end{array}$ & $\begin{array}{c}0.007 \\
(0.366)\end{array}$ & $\begin{array}{c}0.057 * * * \\
(0.000)\end{array}$ \\
\hline Loss & $\begin{array}{c}-0.020 * \\
(0.057)\end{array}$ & $\begin{array}{c}0.006 \\
(0.521)\end{array}$ & $\begin{array}{c}-0.011 \\
(0.231)\end{array}$ & $\begin{array}{c}0.005 \\
(0.576)\end{array}$ \\
\hline AnalystCover & $\begin{array}{c}0.033^{* * *} \\
(0.000)\end{array}$ & $\begin{array}{c}-0.017 * * \\
(0.014)\end{array}$ & $\begin{array}{c}0.031^{* * *} \\
(0.000)\end{array}$ & $\begin{array}{c}-0.009 \\
(0.159)\end{array}$ \\
\hline IndexStock & $\begin{array}{c}0.036 * * * \\
(0.000)\end{array}$ & $\begin{array}{c}0.013 \\
(0.101)\end{array}$ & $\begin{array}{c}0.021^{* * *} \\
(0.010)\end{array}$ & $\begin{array}{c}-0.001 \\
(0.904)\end{array}$ \\
\hline$A D R$ & $\begin{array}{c}-0.000 \\
(0.992)\end{array}$ & $\begin{array}{c}-0.034 * * \\
(0.041)\end{array}$ & $\begin{array}{c}0.020 \\
(0.135)\end{array}$ & $\begin{array}{c}-0.005 \\
(0.675)\end{array}$ \\
\hline \multicolumn{5}{|l|}{ Country-level controls } \\
\hline$G D P$ & $\begin{array}{c}0.026 * * * \\
(0.000)\end{array}$ & $\begin{array}{c}0.061^{* * *} \\
(0.000)\end{array}$ & $\begin{array}{c}-0.015^{* * *} \\
(0.001)\end{array}$ & $\begin{array}{c}0.021 * * * \\
(0.000)\end{array}$ \\
\hline MktCap_GDP & $\begin{array}{c}0.087^{* * * *} \\
(0.000)\end{array}$ & $\begin{array}{c}0.017 * \\
(0.092)\end{array}$ & $\begin{array}{c}-0.057^{* * *} \\
(0.000)\end{array}$ & $\begin{array}{c}-0.010 \\
(0.226)\end{array}$ \\
\hline GDPGrowth & $\begin{array}{c}-0.020 * * * \\
(0.000)\end{array}$ & $\begin{array}{c}-0.004 \\
(0.277)\end{array}$ & $\begin{array}{c}0.009 * * * \\
(0.001)\end{array}$ & $\begin{array}{c}0.000 \\
(0.948)\end{array}$ \\
\hline Trade & $\begin{array}{c}0.057 * * * \\
(0.000)\end{array}$ & $\begin{array}{c}0.151^{* * *} \\
(0.000)\end{array}$ & $\begin{array}{c}-0.050 * * * \\
(0.001)\end{array}$ & $\begin{array}{c}0.057 * * * \\
(0.000)\end{array}$ \\
\hline Industry Fixed Effects & YES & YES & YES & YES \\
\hline
\end{tabular}




\begin{tabular}{l|cc|cc}
\cline { 2 - 5 } Difference in $\beta_{1}$ & \multicolumn{2}{|c|}{$0.039^{* * *}$} & \multicolumn{2}{c}{$0.014^{*}$} \\
$(p$-value $)$ & \multicolumn{2}{|c|}{$(0.002)$} & $4,087)$ \\
\hline $\mathrm{N}$ & 4,744 & 4,284 & 4,284 & 4,744 \\
Adjusted $\mathrm{R}^{2}$ & 0.1169 & 0.1303 & 0.1532 & 0.1611 \\
\hline
\end{tabular}

This article is protected by copyright. All rights reserved. 
TABLE 6 Cross-sectional analysis - Accounting comparability

This table presents analysis of cross-sectional differences in the changes in financial integration measures for mandatory adopters of IFRS. This table reports sample distribution by country. Mandatory adopters are firms that switched from local GAAP to IFRS in 2005 or 2006 and are located in countries that mandated IFRS adoption in 2005. We partition the sample based on the firm's change in accounting comparability from pre- to post-IFRS period. Large (Small) group includes firms with changes in accounting comparability above (below) the third quartile in the sample. Refer to the Appendix for the definitions of all variables. Reported in parentheses are the $p$-values based on two-tailed tests and firm-cluster adjusted standard errors. ***, **, and * indicate significance at the $1 \%, 5 \%$ and $10 \%$ level, respectively.

\begin{tabular}{|c|c|c|c|c|}
\hline & \multicolumn{2}{|c|}{ DEP = INTEGRATE } & \multicolumn{2}{|c|}{ DEP $=$ SPEED } \\
\hline & $\begin{array}{l}\text { Large } \\
\text { (1) }\end{array}$ & $\begin{array}{c}\text { Small } \\
(2)\end{array}$ & $\begin{array}{c}\text { Large } \\
(3)\end{array}$ & $\begin{array}{c}\text { Small } \\
(4)\end{array}$ \\
\hline Post $\left(\beta_{1}\right)$ & $\begin{array}{c}0.044 * * * \\
(0.001)\end{array}$ & $\begin{array}{c}0.026 * * * \\
(0.002)\end{array}$ & $\begin{array}{c}0.029 * * \\
(0.016)\end{array}$ & $\begin{array}{c}0.006 \\
(0.382)\end{array}$ \\
\hline Size & $\begin{array}{c}0.017^{* * *} \\
(0.003)\end{array}$ & $\begin{array}{c}0.016^{* * *} \\
(0.000)\end{array}$ & $\begin{array}{c}0.029 * * * \\
(0.000)\end{array}$ & $\begin{array}{c}0.034^{* * *} \\
(0.000)\end{array}$ \\
\hline Turnover & $\begin{array}{c}0.532 \\
(0.326)\end{array}$ & $\begin{array}{c}1.272 * * * \\
(0.001)\end{array}$ & $\begin{array}{c}0.508 \\
(0.305)\end{array}$ & $\begin{array}{l}0.687 * * \\
(0.042)\end{array}$ \\
\hline Volatility & $\begin{array}{c}0.470 \\
(0.276)\end{array}$ & $\begin{array}{c}0.089 \\
(0.718)\end{array}$ & $\begin{array}{c}0.408 \\
(0.275)\end{array}$ & $\begin{array}{l}0.588^{* *} \\
(0.010)\end{array}$ \\
\hline TradingDay & $\begin{array}{c}0.013 \\
(0.303)\end{array}$ & $\begin{array}{c}0.029 * * * \\
(0.002)\end{array}$ & $\begin{array}{c}0.012 \\
(0.510)\end{array}$ & $\begin{array}{l}0.023^{* *} \\
(0.017)\end{array}$ \\
\hline Loss & $\begin{array}{l}-0.012 \\
(0.530)\end{array}$ & $\begin{array}{l}-0.017 \\
(0.170)\end{array}$ & $\begin{array}{c}0.023 \\
(0.148)\end{array}$ & $\begin{array}{l}-0.003 \\
(0.803)\end{array}$ \\
\hline AnalystCover & $\begin{array}{l}0.024^{*} \\
(0.088)\end{array}$ & $\begin{array}{c}0.010 \\
(0.266)\end{array}$ & $\begin{array}{l}0.025^{*} \\
(0.064)\end{array}$ & $\begin{array}{c}0.004 \\
(0.579)\end{array}$ \\
\hline IndexStock & $\begin{array}{l}0.041^{* *} \\
(0.013)\end{array}$ & $\begin{array}{c}0.006 \\
(0.552)\end{array}$ & $\begin{array}{c}0.007 \\
(0.677)\end{array}$ & $\begin{array}{l}-0.013 \\
(0.191)\end{array}$ \\
\hline$A D R$ & $\begin{array}{l}-0.069 \\
(0.102)\end{array}$ & $\begin{array}{l}-0.001 \\
(0.963)\end{array}$ & $\begin{array}{c}0.003 \\
(0.925)\end{array}$ & $\begin{array}{l}-0.006 \\
(0.678)\end{array}$ \\
\hline Industry Fixed Effects & YES & YES & YES & YES \\
\hline Country Fixed Effects & YES & YES & YES & YES \\
\hline $\begin{array}{l}\text { Difference in } \beta_{1} \\
\text { (p-value) }\end{array}$ & \multicolumn{2}{|c|}{$\begin{array}{c}0.018^{*} \\
(0.076) \\
\end{array}$} & \multicolumn{2}{|c|}{$\begin{array}{l}0.023^{*} \\
(0.053)\end{array}$} \\
\hline $\begin{array}{l}\mathrm{N} \\
\text { Adjusted } \mathrm{R}^{2}\end{array}$ & $\begin{array}{l}1,116 \\
0.1052\end{array}$ & $\begin{array}{c}3,272 \\
0.1107\end{array}$ & $\begin{array}{c}1,116 \\
0.1226\end{array}$ & $\begin{array}{c}3,272 \\
0.1485 \\
\end{array}$ \\
\hline
\end{tabular}


TABLE 7 Cross-sectional analysis - Increases in foreign institutional ownership

This table presents analysis of cross-sectional difference in the changes in financial integration measures for mandatory adopters of IFRS. This table reports sample distribution by country. Mandatory adopters are firms that switched from local GAAP to IFRS in 2005 or 2006 and are located in countries that mandated IFRS adoption in 2005. We partition the sample based on the firm's change in the mean foreign ownership from preto post-IFRS period. Large (Small) group includes firms with changes in foreign ownership above (below) the third quartile of the sample. Refer to the Appendix for the definitions of all variables. Reported in parentheses are the $p$-values based on two-tailed tests and firm-cluster adjusted standard errors. ${ }^{* * *}, * *$, and $*$ indicate significance at the $1 \%, 5 \%$ and $10 \%$ level, respectively.

\begin{tabular}{|c|c|c|c|c|}
\hline & \multicolumn{2}{|c|}{ DEP = INTEGRATE } & \multicolumn{2}{|c|}{ DEP $=S P E E D$} \\
\hline & $\begin{array}{l}\text { Large } \\
(1)\end{array}$ & $\begin{array}{c}\text { Small } \\
(2)\end{array}$ & $\begin{array}{l}\text { Large } \\
(3)\end{array}$ & $\begin{array}{c}\text { Small } \\
(4)\end{array}$ \\
\hline Post $\left(\beta_{1}\right)$ & $\begin{array}{c}0.080 * * * \\
(0.003)\end{array}$ & $\begin{array}{c}0.045 * * * \\
(0.006)\end{array}$ & $\begin{array}{l}0.047 * * \\
(0.018)\end{array}$ & $\begin{array}{c}0.012 \\
(0.272)\end{array}$ \\
\hline Size & $\begin{array}{c}0.009 \\
(0.345)\end{array}$ & $\begin{array}{c}0.007 \\
(0.265)\end{array}$ & $\begin{array}{c}0.035^{* * *} \\
(0.000)\end{array}$ & $\begin{array}{c}0.037^{* * *} \\
(0.000)\end{array}$ \\
\hline Turnover & $\begin{array}{l}1.214 \\
(0.129)\end{array}$ & $\begin{array}{c}0.358 \\
(0.539)\end{array}$ & $\begin{array}{l}-0.281 \\
(0.580)\end{array}$ & $\begin{array}{c}0.330 \\
(0.488)\end{array}$ \\
\hline Volatility & $\begin{array}{c}0.544 \\
(0.539)\end{array}$ & $\begin{array}{l}1.046^{* *} \\
(0.029)\end{array}$ & $\begin{array}{c}0.986 \\
(0.195)\end{array}$ & $\begin{array}{c}1.031^{* * *} \\
(0.000)\end{array}$ \\
\hline TradingDay & $\begin{array}{c}0.019 \\
(0.495)\end{array}$ & $\begin{array}{l}0.082 * \\
(0.076)\end{array}$ & $\begin{array}{c}0.021 \\
(0.367)\end{array}$ & $\begin{array}{l}0.082^{* *} \\
(0.022)\end{array}$ \\
\hline Loss & $\begin{array}{l}-0.056 \\
(0.397)\end{array}$ & $\begin{array}{l}-0.001 \\
(0.971)\end{array}$ & $\begin{array}{l}-0.001 \\
(0.987)\end{array}$ & $\begin{array}{l}-0.014 \\
(0.551)\end{array}$ \\
\hline AnalystCover & $\begin{array}{c}0.010 \\
(0.678)\end{array}$ & $\begin{array}{c}0.001 \\
(0.923)\end{array}$ & $\begin{array}{c}0.019 \\
(0.285)\end{array}$ & $\begin{array}{c}0.014 \\
(0.244)\end{array}$ \\
\hline IndexStock & $\begin{array}{l}-0.096 * \\
(0.072)\end{array}$ & $\begin{array}{l}0.063 * * \\
(0.034)\end{array}$ & $\begin{array}{l}-0.005 \\
(0.902)\end{array}$ & $\begin{array}{l}0.060^{* *} \\
(0.030)\end{array}$ \\
\hline$A D R$ & $\begin{array}{l}-0.015 \\
(0.709)\end{array}$ & $\begin{array}{c}-0.036^{* *} \\
(0.024)\end{array}$ & $\begin{array}{l}-0.014 \\
(0.534)\end{array}$ & $\begin{array}{c}-0.032 * * \\
(0.015)\end{array}$ \\
\hline $\begin{array}{l}\text { Industry Fixed Effects } \\
\text { Country Fixed Effects }\end{array}$ & YES & YES & YES & YES \\
\hline $\begin{array}{l}\text { Difference in } \beta_{1} \\
\text { (p-value) }\end{array}$ & \multicolumn{2}{|c|}{$\begin{array}{c}0.035^{* *} \\
(0.038)\end{array}$} & \multicolumn{2}{|c|}{$\begin{array}{c}0.035^{* *} \\
(0.041)\end{array}$} \\
\hline $\begin{array}{l}\mathrm{N} \\
\text { Adjusted } \mathrm{R}^{2}\end{array}$ & $\begin{array}{c}398 \\
0.1206\end{array}$ & $\begin{array}{c}1,171 \\
0.2005\end{array}$ & $\begin{array}{c}398 \\
0.1354\end{array}$ & $\begin{array}{c}1,171 \\
0.1748\end{array}$ \\
\hline
\end{tabular}




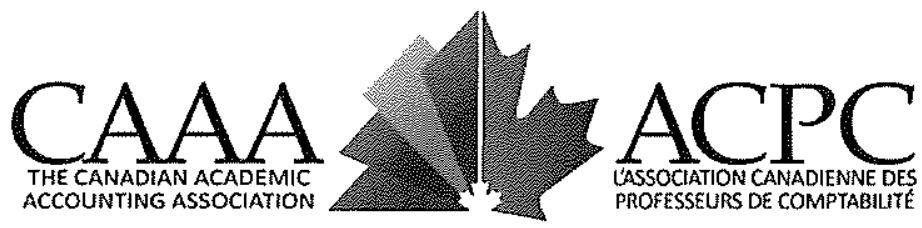

\section{COPYRIGHT TRANSFER AGREEMENT CONTEMPORARY ACCOUNTING RESEARCH (CAR)}

Date: Oct.18,2018

Contributor name(s): Yan Li

Contributor address(es): 198 Berkeley Street, Cariton, VIC3010

Manuscript number: $2015-273$

Re: Manuscript entitled Accounting Standards Harmonization and Financial Integration (the"Contribution")

for publication in Contemporary Accounting Research (the "Journal")

published by the Canadian Academic Accounting Association (the "Owner")

Dear Contributor(s):

Thank you for submitting your Contribution for publication. In order to expedite the editing and publishing process and enable the Owner to disseminate your Contribution to the fullest extent, we need to have this Copyright Transfer Agreement executed. If the Contribution is not accepted for publication, or if the Contribution is subsequently rejected, this Agreement shall be null and void.

Publication cannot proceed without a signed copy of this Agreement.

\section{A. COPYRIGHT}

1. In consideration of Owner's publication of the Contribution in the Journal, the Contributor(s) assigns to the Owner, during the full term of copyright and any extensions or renewals, all copyright in and to the Contribution, and all rights therein, including but not limited to the right to publish, republish, transmit, sell, distribute and otherwise use the Contribution in whole or in part in electronic and print editions of the Journal and in derivative works throughout the world, in all languages and in all media of expression now known or later developed, and to license or permit others to do so.

2. Reproduction, posting, transmission or other distribution or use of the final Contribution in whole or in part in any medium by the Contributor as permitted by this Agreement requires a citation to the Journal suitable in form and content as follows: (Title of Article, Contributor, Journal Title and Volume/Issue, Copyright (c) [year], copyright owner as specified in the Journal, Publisher). Links to the final article on the publisher website are encouraged where appropriate.

\section{B. RETAINED RIGHTS}

Notwithstanding the above, the Contributor(s) or, if applicable, the Contributor's employer, retains all proprietary rights other than copyright, such as patent rights, in any process, procedure or article of manufacture described in the Contribution.

\section{PERMITTED USES BY CONTRIBUTOR}

1. Submitted Version. The Owner licenses back the following rights to the Contributor(s) in the version of the Contribution as originally submitted to the Journal for publication:

a. The right to self-archive on the Contributor's personal website, place in a not for profit subject-based preprint server or repository, or in the Contributor's company/ institutional 
repository or archive. This right extends to both intranets and the Internet. The Contributor may not update the submitted version or replace it with the accepted or the published Contribution. The version posted must acknowledge acceptance for publication and, following publication of the final Contribution, contain a legend as follows: This is the pre-peer reviewed version of the following article: FULL CITE, which has been published in final form at [Link to final article]. Contributors are not required to remove preprints posted to not for profit preprint servers prior to submission of the Contribution.

2. Accepted Version. The Owner licenses back the following rights to the Contributor in the version of the Contribution accepted by the Journal for publication:

a. The right to self-archive the peer-reviewed (but not final) version of the Contribution on the Contributor's personal website, in the Contributor's company/institutional repository or archive, and in certain not for profit subject-based repositories such as, but not limited to, PubMed Central as listed at the following website: http://olabout.wiley.com/WileyCDA/Section/id-406074.html, subject to an embargo period of 12 months for scientific, technical and medical (STM) journals and 24 months for social science and humanities (SSH) journals following publication of the final Contribution. There are separate arrangements with certain funding agencies governing reuse of this version as set forth at the following website: http://www.wiley.com/go/funderstatement. Unless otherwise specified, the accepted version of the contribution must be self-archived in accordance with Wiley's Terms and Conditions for Self-Archiving. The Contributor may not update the accepted version or replace it with the published Contribution. The version posted must contain a legend as follows: This is the accepted version of the following article: FULL CITE, which has been published in final form at [Link to final article].

b. The right to transmit, print and share copies with colleagues, provided that there is no systematic distribution of the accepted version, e.g. posting on a listserve, network (including scientific social networks) or automated delivery.

\subsection{Accepted Version and Compliance with Open Access Policies on Publications. The} Contributor(s) may make a written request of the Owner for a limited license to comply solely as is necessary with section 3 of the open access policy published by the Government of Canada's Canadian Institutes of Health Research (CIHR), the Natural Sciences and Engineering Research Council of Canada (NSERC) and the Social Sciences and Humanities Research Council of Canada (SSHRC): http://www.science.gc.ca/default.asp?lang $=E n \& n=F 6765465-1$ or to comply solely as is necessary with any other substantially similar open access policy of a substantially similar government agency ("Open Access Policy"). Such written request shall specify Contributor(s) proposed Open Access Policycompliant use. Owner's decision to grant such license to the Contributor(s) in respect of such specified requested use shall be at its sole discretion, and no such license shall be valid unless it is provided by Owner to the Contributor(s) in writing, in advance.

3. Final Published Version. The Owner hereby licenses back to the Contributor the following rights with respect to the final version of the Contribution published by Wiley Periodicals, Inc.:

a. Copies for colleagues. The personal right of the Contributor only to send or transmit individual copies of the final published version in any format to colleagues upon their specific request provided no fee is charged, and further provided that there is no systematic distribution of the Contribution, e.g. posting on a listserve, network or automated delivery.

b. Re-use in other publications. Subject to the conditions set out in section 4.b (excluding that pertaining to word count), the right to re-use the final Contribution for any publication authored or edited by the Contributor (excluding journal articles) where such re-used material constitutes less than half of the total material in such publication. In such case, any modifications shall be accurately noted.

c. Teaching duties. The right to include the Contribution in teaching or training duties at the Contributor's institution/place of employment including in course packs, e-reserves, 
presentation at professional conferences, in-house training, or distance learning. The Contribution may not be used in seminars outside of normal teaching obligations (e.g. commercial seminars). Electronic posting of the final published version in connection with teaching/training at the Contributor's company/institution is permitted subject to the implementation of reasonable access control mechanisms, such as user name and password. Posting the final published version on the open Internet is not permitted.

d. Oral presentations. The right to make oral presentations based on the Contribution.

\section{Article Abstracts, Figures, Tables, Data Sets, Artwork and Selected Text (up to 250 words).}

a. Contributors may re-use unmodified abstracts for any non-commercial purpose. For online uses of the abstracts, the Owner encourages but does not require linking back to the final published versions.

b. Contributors may re-use figures, tables, data sets, artwork, and selected text up to 250 words from their Contributions, provided the following conditions are met:

(i) Full and accurate credit must be given to the Contribution.

(ii) Modifications to the figures, tables and data must be noted. Otherwise, no changes may be made.

(iii) The re-use may not be made for direct commercial purposes, or for financial consideration to the Contributor.

(iv) Nothing herein shall permit dual publication in violation of journal ethical practices.

\section{CONTRIBUTIONS OWNED BY EMPLOYER}

1. If the Contribution was written by the Contributor in the course of the Contributor's employment (as a "work-made-for-hire" in the course of employment), the Contribution is owned by the company/institution which must execute this Agreement (in addition to the Contributor's signature). In such case, the company/institution hereby assigns to the Owner, during the full term of copyright, all copyright in and to the Contribution for the full term of copyright throughout the world as specified in paragraph $\mathrm{A}$ above.

For company/institution-owned work, signatures cannot be collected electronically and so instead please print off this Agreement, ask the appropriate person in your company/institution to sign the Agreement as well as yourself in the space provided below, and email a scanned copy to the Journal production editor. For production editor contact details, please visit the Journal's online author guidelines.

2. In addition to the rights specified as retained in paragraph $B$ above and the rights granted back to the Contributor pursuant to paragraph $\mathrm{C}$ above, the Owner hereby grants back, without charge, to such company/institution, its subsidiaries and divisions, the right to make copies of and distribute the final published Contribution internally in print format or electronically on the Company's internal network. Copies so used may not be resold or distributed externally. However, the company/institution may include information and text from the Contribution as part of an information package included with software or other products offered for sale or license or included in patent applications. Posting of the final published Contribution by the company/institution on a public access website may only be done with written permission, and payment of any applicable fee(s). Also, upon payment of the applicable reprint fee, the company/institution may distribute print copies of the published Contribution externally. 


\section{E. GOVERNMENT CONTRACTS}

In the case of a Contribution prepared under U.S. Government contract or grant, the U.S. Government may reproduce, without charge, all or portions of the Contribution and may authorize others to do so, for official U.S. Government purposes only, if the U.S. Government contract or grant so requires. (U.S. Government, U.K. Government, and other government employees: see notes at end.)

\section{F. COPYRIGHT NOTICE}

The Contributor and the company/institution agree that any and all copies of the final published version of the Contribution or any part thereof distributed or posted by them in print or electronic format as permitted herein will include the notice of copyright as stipulated in the Journal and a full citation to the Journal.

\section{G. CONTRIBUTOR'S REPRESENTATIONS}

The Contributor(s) represents that the Contribution is the Contributor's original work. If the Contribution was prepared jointly, all individuals identified as Contributors actually contributed to the Contribution, and all individuals who contributed are included. The Contribution is submitted only to this Journal and has not been published before. (If excerpts from copyrighted works owned by third parties are included, the Contributor(s) will obtain written permission from the copyright owners for all uses as set forth in the Journal's Instructions for Contributors, and show credit to the sources in the Contribution.) The Contributor(s) also warrants that the Contribution contains no libelous or unlawful statements, does not infringe upon the rights (including without limitation the copyright, patent or trademark rights) or the privacy of others, or contain material or instructions that might cause harm or injury. The Contributor(s) further warrants that there are no conflicts of interest relating to the Contribution, except as disclosed. The Contributor (or in the case of jointly prepared Contribution, the Contributors) shall indemnify and hold the Owner harmless from any and all claims, damages, liabilities, costs and expenses (including counsel fees) that the Owner incurs or sustains arising out of any breach by the Contributor(s) of the foregoing warranties. If the term "Contributor" as used herein refers to more than one person, the obligations of the Contributor shall be both joint and several.

\section{H. GOVERNING LAW}

Regardless of its place of physical execution or performance, the provisions of this Copyright Transfer Agreement shall in all respects be construed according to, and the rights and liabilities of the parties hereto shall in all respects be governed by, the laws of the Province of Ontario and the federal laws of Canada applicable therein. The parties hereto attorn to the jurisdiction of the courts of Ontario.

By signing below, I agree to the COPYRIGHT TRANSFER AGREEMENT as shown above.

Contributor's signature:_

Type or print name here: Yan Li

Date: Ocl. 18,2018

By signing below, we each agree to the COPYRIGHT TRANSFER AGREEMENT as shown above.

Joint Contributor's signature:

Type or print name here: Wen He

Date: $24 / 10 / 2018$ 
Joint Contributor's signature: Roynolu
Type or print name here: RAYNOLDE $\quad$ REREIRP

Date: DCt 26,2018

Joint Contributor's signature:

Type or print name here

Date:

\section{SELECT FROM OPTIONS BELOW:}

\section{[X Contributor-owned work}

U.S. Government work

Note to U.S. Gavernment Employees

A contribution prepared by a U.S. federal government employee as part of the employee's afficial dutles, or which is an official U.S. Government publication, is called a "U.S. Government work", and is in the publle domain in the United States. In such case, Paragraph A.1 will not apply but the Contributor must type his/her name (in the Contributor's slgnature line) above. Contributor acknowledges that the Contribution will be published in the United States and other countries. If the Contribution was not prepared as part of the employee's duties or is not an official U.S. Government publlcation, it is not a U.S. Government work.

U.K. Government work (Crown Copyright)

Note to U.K. Government Employees

For Crown Copyright this form cannot be completed electronically and should be printed off, signed in the Contributor's signatures section above by the appropriately authorized individual and returned to the Journal production editor by email. For production editor contact details, please vislt the Journal's online author guidelines. The rights in a contribution prepared by an employee of a U.K. government department, agency or other Crown body as part of his/her official duties, or which is an official government publication, belong to the Crown. Contributors must ensure they comply with departmental regulations and submit the appropriate authorization to publlsh. If your status as a government employee legally prevents you from signing this Agreement, please contact the Journal production editor.

Other Including Other Government work or Non-Governmental Organization work Note to Non-U.S., Non-U.K. Government Employees or Non-Governmental Onganization Employees For Other Government or Non-Governmental Organization work this form cannot be completed electronically and should be printed off, signed in the Contributor's signatures section above by the appropriately authorized individual and returned to the Journal production editor by email. For production edltor contact details, please vislt the Journal's online author guldelines. If you are employed by the Department of Veterans Affairs in Australia, the World Bank, the International Monetary Fund, the European Atomic Energy Community, the Jet Propulsion Laboratory at Callfornia Institute of Technology, or are a Canadlan Government civil servant, please download a copy of the approprlate license agreement from

http://authorservices. wiley.com/bauthor/fags copyright.asp and return it to the Journal production editor. If your status as a government or non-governmental organization emplovee legally prevents you from signing this Agreement, please contact the Journal production editor.

Name of Government/Non-Governmental Organization:

Please subnit this Copyright Transfer Agreement via your Author Login page in Editorial Manager
The Canadian Academic Accounting Association $1800-80$ Bloor St W., Toronto, ON. MSS 2 V1 +1 (416) 486-5631 
$\square$ Company/institution owned work (made for hire in the course of employment) For "work made for hire" this form cannot be completed electronically and should be printed off, signed and returned to the Journal production editor by email. For production editor contact details, please visit the Journal's online author guidelines. If you are an employee of Amgen, please download a copy of the company addendum from

http://authorservices. wiley.com/bauthor/faqs copyright.asp and return your signed license agreement along with the addendum.

Name of Company/Institution:

Authorized Signature of Employer:

Date:

Signature of Employee:

Date:

The Canadian Academic Accounting Association 1800-80 Bloor St W., Toronto, ON.

M5S 2V1 +1 (416) 486-5631

This article is protected by copyright. All rights reserved. 


\title{
Accounting Standards Harmonization and Financial Integration*
}

\author{
Dan Dhaliwal \\ Department of Accounting \\ University of Arizona \\ (deceased) \\ Wen $\mathrm{He}$ \\ UQ Business School \\ The University of Queensland \\ wen.he@uq.edu.au \\ Yan $\mathrm{Li}^{\dagger}$ \\ Department of Accounting \\ University of Melbourne \\ yan.li@unimelb.edu.au \\ Raynolde Pereira \\ School of Accountancy \\ University of Missouri \\ pereirar@missouri.edu
}

October 2018

\footnotetext{
* Accepted by Michael Welker. We are grateful to the valuable comments and suggestions from two anonymous referees, Michael Welker (the editor and the Editor-in-Chief), Jeff Pittman (the deputy Editor-in-Chief), Margaret Abernethy, Jeffrey Callen, Mark DeFond, Bin Ke, Charles Lee, Matthew Pinnuck, Shiva Rajgopal, Eddie Riedl (discussant), Jianfeng Shen, Siew Hong Teoh, Joanna Wu (discussant), and Bohui Zhang. This paper has also benefited from the comments of the discussants and workshop participants at the FARS 2013 conference, the EAA 2013 annual congress, the CAAA 2013 annual meeting, the AAA 2013 annual meeting, MIT-Asia 2014 conference, University of Queensland, University of Melbourne, University of Western Australia, and Xiamen University. Yan Li acknowledges the financial support from Singapore MOE Tier 1 academic research fund. $\dagger$ Corresponding author: yan.li@ unimelb.edu.au
} 


\title{
Accounting Standards Harmonization and Financial Integration
}

\begin{abstract}
We empirically examine whether adopting a uniform set of accounting standards mitigates information frictions in financial markets and facilitates market integration. Using a difference-in-difference design, we find that after the mandatory adoption of International Financial Reporting Standards (IFRS), local stock returns incorporate more global information and at a faster speed. The effect of IFRS adoption is stronger in countries where there are larger improvements in accounting comparability and for firms with a larger increase in foreign ownership. Overall, our results suggest that accounting standards harmonization facilitates financial market integration.
\end{abstract}




\section{Introduction}

Over the past few decades, financial markets around the world have become increasingly integrated due to the gradual removal of capital controls and efforts to promote market integration. However, significant financial market segmentation still exists (Giannetti et al. 2002; Bekaert et al. 2011). One reason for incomplete market integration is information frictions that prevent investors from collecting, processing, and using value relevant information in a timely manner (Bekaert 1995; Bekaert et al. 2003). In particular, accounting standards differ from country to country, making it difficult for global investors to compare and interpret accounting numbers across countries (Covrig et al. 2007). In 2005, a number of countries around the world adopted International Financial Reporting Standards (IFRS) to provide global investors with comparable financial information by using a uniform set of accounting standards. In this study, we use mandatory adoption of IFRS to investigate whether accounting standards harmonization facilitates financial market integration.

Based on the law of one price, researchers in international finance conclude that in fully integrated markets securities are priced based on their exposure to non-diversifiable global risk factors (Stulz 1981; Errunza and Losq 1985). For example, Bekaert and Harvey $(1995,403)$ state that "markets are completely integrated if assets with the same risk have identical expected returns irrespective of the market.” Pukthuanthong and Roll (2009) propose that markets could be globally integrated as long as the same global risk factors determined the prices of all the stocks in all countries. ${ }^{1}$ The attention on financial integration is due to the range of benefits identified by the literature including a lower cost of capital (Errunza and Losq 1985; Henry 2000a), more corporate investments (Henry 2000b), and higher economic growth (Bekaert and Harvey 2001). In light of these positive effects, many countries implemented various policies to achieve financial and economic integration, including opening domestic markets to foreign investors, removing foreign exchange controls, and promoting international trade and investment through free trade agreements.

\footnotetext{
${ }^{1}$ Specifically, Pukthuanthong and Roll $(2009,215)$ state that "We contend that markets could be globally integrated even if assets were irrationally priced so long as the same global shocks permeate all countries. We do not mean to say that all or any shocks are irrational, but if some are, markets would still be integrated if the same irrationalities propagate globally." This statement implies that irrational shocks could be contagious or spread across integrated markets, but Karolyi (2003) surveys the literature and concludes that there is no clear evidence of the existence of financial market contagion.
} 
The literature on IFRS adoption has provided some evidence that foreign investment increased following mandatory IFRS adoption. ${ }^{2}$ For example, some studies find IFRS adoption leads to an increase in equity ownership by foreign investors (DeFond et al. 2011; Florou and Pope 2012; Yu and Wahid 2014), more cross-border mergers and acquisitions (Francis et al. 2012; Louis and Urcan 2014), and more foreign direct investments (Gordon et al. 2012). While increases in foreign investment imply economic integration, these studies do not provide direct evidence on whether financial integration improved and stock prices became more driven by global risk factors following IFRS adoption. In fact, international finance literature suggests that economic integration is not necessarily linked to financial integration. For example, Bekaert and Harvey (1995) point out that market integration is a complex process and markets could remain segmented even though foreigners may have relatively easy access to local capital markets. Bekaert et al. (2013) show the adoption of the Euro as a single currency in Europe, which should have removed exchange rate risks and improved economic integration, did not lead to improved market integration in European countries. ${ }^{3}$

Furthermore, the effect of IFRS adoption on foreign investment appears to be small in magnitude. DeFond et al. (2011) estimate that mandatory IFRS adoption results in a mere $0.8 \%$ increase in foreign mutual fund ownership, leaving it unclear whether such a small increase in foreign ownership can effectively improve financial integration. Therefore, it remains an open empirical question whether the accounting harmonization achieved through mandatory IFRS adoption leads to more integrated financial markets. Given the economic benefits of financial market integration documented in the literature, we believe that it is important to document direct evidence of the effect of IFRS adoption induced accounting harmonization on financial market integration.

To assess the impact of IFRS adoption on financial integration, we focus on two firm-level measures of financial integration based on the extent to which equity prices are driven by global risk factors. ${ }^{4}$ The first measure is the proportion of stock return variations that can be explained by global

\footnotetext{
${ }^{2}$ Please refer to De George et al. (2016) for a recent review of IFRS literature.

${ }^{3}$ A different view is expressed by Kalemli-Ozcan et al. (2008) who show that the adoption of the Euro has a positive impact on cross-border banking activities and consumption risk sharing.

${ }^{4}$ Many papers on market integration use country-level measures. In our setting, we choose firm-level measures because in a number of countries firms could voluntarily adopt IFRS (or its precedent IAS) before it was mandated
} 
market returns, with a larger proportion indicating a higher degree of integration. This measure follows Pukthuanthong and Roll $(2009,214)$ who propose that "a sensible intuitive quantitative measure of financial market integration is the proportion of a country's returns that can be explained by global factors." The measure has the advantage of being consistent with the theory of financial integration ${ }^{5}$ but does not rely on any specific international asset pricing model. The second measure captures the speed at which global information is incorporated into stock prices, with faster speed indicating more integrated markets. The rationale for this measure is that in fully integrated markets, shocks to global risk factors should quickly transmit across markets without delay so that integrated markets are also efficient markets. Consistent with this view, Bae et al. (2012) find that global information is incorporated into local stock prices in a more timely manner in the markets that are more accessible to foreign investors.

Following the literature, we use a difference-in-difference approach to isolate the effects of mandatory IFRS adoption while accounting for other factors that may contribute to financial integration. We use the year 2005 as a cut-off year to compare pre- and post-IFRS adoption regimes. Our sample consists of firm-level observations from 34 countries: 17 countries imposed mandatory adoption of IFRS in 2005 while the remaining 17 countries did not adopt IFRS in 2005. Our main analysis distinguishes between mandatory IFRS adopters and non-adopters. We classify as "mandatory adopters" firms that applied IFRS only after their countries mandated IFRS adoption in 2005. In contrast, "nonadopters" are firms that are located in non-adopting countries and apply domestic accounting standards throughout our sample period from 2003 to 2007.

Our univariate tests indicate that financial integration increased significantly after 2005 for both mandatory IFRS adopters and non-adopters. This evidence is consistent with the contention that barriers to financial integration have declined over time (Pukthuanthong and Roll 2009). However, the magnitude of improvement in financial integration is significantly greater for mandatory adopters than for non-adopters, suggesting that harmonizing accounting standards contributes effectively to global

nationwide. Country-level measures are based on all firms in a country and are thus unable to provide a clean test on the effect of mandatory IFRS adoption.

${ }^{5}$ For example, Bekaert and Harvey $(1995,403)$ point out that "If a market is segmented from the rest of the world, its covariance with a common world factor may have little or no ability to explain its expected return." 
financial integration. We obtain similar results in multivariate analyses in which we control for various firm characteristics such as firm size, operational performance, stock liquidity, and analyst coverage, as well as industry fixed effects and country-level controls. Our results remain robust in a range of robustness tests, such as using US firms only as benchmarks, using different measures of global returns, using different databases and samples, controlling for financial reforms, and placebo tests.

We explore two channels through which mandatory IFRS adoption facilitates financial market integration. The first channel is the transmission of global information across markets. A uniform set of high quality accounting standards achieves accounting harmonization and consequently makes accounting information more comparable across markets, which, in turn, should allow investors to better interpret value-relevant information from global markets and to adjust local prices to incorporate the global information in a full and more timely manner. Consistent with this view, Tan et al. (2011) find that mandatory IFRS adoption helps local firms to attract coverage by foreign financial analysts and enables foreign analysts to issue more accurate forecasts for local firms. Wang (2014) finds that local firms' stock prices respond more strongly to earnings news announced by foreign firms that use the same accounting standards as local firms, implying that comparable accounting information facilitates investors' response to global information contained in foreign firms' announcements. ${ }^{6} \mathrm{We}$ thus expect that the effect of mandatory IFRS adoption on financial integration increases with the extent to which accounting harmonization related to IFRS adoption improves accounting comparability. To test this expectation, we use two measures of improvements in accounting comparability, one at country level and the other at firm level. The first measure is the difference between local GAAP and IFRS, with a larger difference indicating a larger improvement since the mandatory IFRS adoption eliminated the differences. The second measure follows De Franco et al. (2011) and Yip and Young (2012) and is an ex post measure of improvements in accounting comparability based on the mapping between stock returns and earnings using peer firms' data. With both measures of accounting comparability, we find

\footnotetext{
${ }^{6}$ Note here that both local and foreign investors can better respond to global information from foreign firms if the information is more comparable. This implies that financial integration can be achieved even without foreign investment, as long as local investors can observe the global information and price local stocks according to their exposure to global risk factors.
} 
that the effect of IFRS adoption on financial integration is more pronounced in adopting countries with greater improvements in accounting comparability.

The second channel is capital mobility and foreign equity investment. Prior studies have documented that IFRS adoption leads to an increase in foreign equity ownership (DeFond et al. 2011; Yu and Wahid 2014), and foreign investors are better able to incorporate global information into local share prices (Bae et al. 2012). We thus expect that IFRS adoption has a more pronounced impact on financial integration if the adoption contributes to larger improvements in foreign ownership. To empirically evaluate this contention, we examine whether the relation between financial integration and IFRS adoption is more pronounced when it is accompanied by a marked improvement in foreign investor ownership. Using institutional ownership data from the FactSet database to compute changes in foreign institutional ownership from the pre- to the post-mandatory IFRS adoption period, we find that the improvement in financial integration following IFRS adoption is greater when it is accompanied by a large increase in foreign ownership.

Our study contributes to the literature in several ways. First, it contributes to the growing literature on the effects of accounting standards, in particular the effects of mandatory IFRS adoption. Barth et al. (2008) compare domestic accounting standards to IAS and find that the latter contributes to higher quality accounting. Focusing on capital markets, prior research finds that IFRS adoption has a favorable impact on the cost of capital (Daske et al. 2008; Li 2010), stock liquidity (Daske et al. 2008), information content of earnings (Landsman et al. 2012), analyst forecast properties (Byard et al. 2011; Horton et al. 2013), and information transfers across countries (Kim and Li 2011; Wang 2014). Of particular relevance to this study is the positive impact of IFRS on the cost of capital. While prior studies explain the lower cost of capital following IFRS adoption by the reduction of information asymmetry or the improvement in information quality (Daske et al. 2008; Li 2010), our evidence suggests another potential explanation for this finding is the improvement in risk sharing due to increased financial integration, as documented in international finance literature (e.g., Henry 2000a).

Amiram (2012), DeFond et al. (2011), and Yu and Wahid (2014) find that IFRS adoption has a positive impact on foreign ownership of local stocks. These findings are important as they show the effectiveness of IFRS in improving the capital flow across geographic borders. However, improvements 
in capital mobility do not imply equivalent improvements in financial integration (Obstfeld and Taylor 2004). Our study complements this stream of research by providing direct evidence on the effect of mandatory IFRS adoption on financial market integration. Consistent with a uniform set of high quality accounting standards reducing information frictions across markets, we find that IFRS adoption induced accounting harmonization is positively associated with financial integration. We also show that the effect of IFRS adoption on financial integration is attributable to the impact of IFRS on capital mobility and global information flow.

Our study also contributes to inquiry on the determinants of financial integration. A range of barriers may limit financial integration, including direct barriers that impose foreign ownership restrictions or limit the amount of direct ownership, or capital controls that restrict the amount of profits remitted or impose taxes on the flow of dividends and capital income (Bekaert 1995). Given these barriers, prior studies focused on whether regulatory changes such as market liberalization and political or currency union (e.g., Bekaert et al. 2002; Bekaert et al. 2013) contribute to market integration. Indirect barriers, such as information costs, also hinder financial integration and capital flows (e.g., Pownall et al. 2014). Our study provides empirical evidence that adopting a uniform set of higher quality accounting standards improves financial integration by reducing information frictions.

The remainder of this paper proceeds as follows. Section 2 reviews the relevant literature and develops hypotheses. Section 3 describes the sample construction and research design issues. Section 4 discusses empirical results, and Section 5 sets forth our conclusions.

\section{Related literature and hypothesis development}

Financial integration has received considerable attention in finance and economics research, partly because of its posited effects on the financial and real sectors of the economy (Bekaert et al. 2003; Henry 2003). The underlying argument is that financial integration lowers a firm's cost of capital by improved risk sharing and as a result positively affects investment and ultimately economic output (Henry 2003). Stulz $(1999,10)$ notes that "where barriers to international investment segment a national capital market from global markets, the local investors bear all the risk of the economic activities in their economy. And, for bearing this risk, such investors require a higher risk premium". In the presence 
of integrated financial markets, foreign investors are allowed to invest in domestic markets and vice versa. Permitting cross-border investment improves risk sharing since a country's risk is borne by both foreign and local investors. In the presence of full financial integration, the resulting implication is that securities that have rights to identical streams of dividends but are issued in different countries will trade at the same price (Stulz 2005). More importantly, the cost of capital is posited to decline since the risk premium involved is adjusted for the risk sharing benefits due to financial integration (Errunza and Losq 1985; Stulz 1999). In support of this contention, Henry (2000a, 2000b) finds that improvements in integration through financial liberalization are associated with reductions in the cost of capital and increases in the level of investment.

Despite the posited benefits, there are barriers that limit the extent of financial integration. Extant literature identifies three classes of barriers (Bekaert 1995). The first class consists of legal barriers that impose specific restrictions or limits on foreign investor ownership. The second class of barriers involves risks related to a country's internal environment, including liquidity, political, economic, and currency risks (Bekaert et al. 2003). The third class of barriers is information related barriers or frictions that can arise from a lack of high quality, comparable accounting information (Bekaert 1995; Bekaert et al. 2003). Accounting statements represent an important source of firmspecific information for investors. For instance, they allow investors to better gauge the financial health of the firm and to evaluate its future prospects. Not surprisingly, Chuhan (1992) finds that investors view information frictions as impediments to cross-border investments.

In this study, we investigate whether accounting harmonization due to the mandatory adoption of IFRS can result in improvements in financial integration by removing information frictions associated with different accounting standards across markets. The aim of the International Accounting Standards Board in formulating IFRS is to "develop, in the public interest, a single set of high quality, understandable and enforceable global accounting standards that require high quality, transparent and comparable information in financial statements and other financial reporting to help participants in the world's capital markets and other users make economic decisions." ${ }^{77}$ In short, the objectives can be

\footnotetext{
${ }^{7}$ The objective of IASB is available at: https://www.iasplus.com/en-gb/standards/other/preface.
} 
summarized as aiming to achieve accounting harmonization. The most direct effect of adoption of a uniform set of accounting standards is the decrease in the cost of collecting and analyzing accounting information in the adopting countries. Since IFRS have been adopted in over 100 countries, it is now less costly for investors to compare and evaluate firms in the adopting countries around the world (Covrig et al. 2007). Even for global investors from non-adopting countries such as the US, the information cost associated with understanding IFRS appears to be a one-off cost since knowledge of IFRS can be applied to all firms in all the adopting countries. Furthermore, a uniform set of accounting standards implies that economic shocks to firms' fundamental operations will be recognized in accounting systems in a consistent way, which allows investors to better assess the systematic global risk and set local prices accordingly. Therefore, mandatory IFRS adoption can mitigate information barriers and facilitate financial integration by increasing the comparability of financial information around the world.

Consistent with this view, prior studies have documented that IFRS adoption facilitated crossborder information transfer and capital investments. DeFond et al. (2011) find improvements in accounting comparability due to IFRS adoption contribute to increases in foreign mutual fund ownership. Beneish et al. (2009) document a positive association between mandatory IFRS adoption and cross-border investments in not only equity but also bond markets. Related research also finds a positive association between IFRS adoption and foreign portfolio holdings (Yu and Wahid 2014), foreign individual investors (Bruggemann et al. 2009), and foreign analysts (Tan et al. 2011). The positive impact of IFRS adoption on cross-border investments is consistent with the argument that IFRS ameliorate the information frictions in the country involved.

IFRS adoption could also affect information frictions by altering the quality of financial reporting, although there is no conclusive evidence on whether adoption increases or decreases accounting quality. Some researchers note that IFRS adoption imposes a more comprehensive set of disclosure requirements than domestic accounting standards (Daske et al. 2008). It has also been argued that IFRS (and the predecessor IAS) constrain managerial discretion (Barth et al. 2008). Others, however, find that IFRS adoption leads to more earnings management and less conservative financial reporting (e.g., Lantto and Sahlström 2009; Ahmed et al. 2013; Lai et al. 2013). To the extent that IFRS 
adoption improves accounting quality, the adoption is likely to further reduce information friction to global investors because higher-quality accounting numbers can decrease information cost and estimation errors in assessing global risk factors.

Despite the argument that IFRS adoption mitigates information frictions by improving accounting comparability, it is far from certain that adopting IFRS will, in and of itself, improve financial integration. There are several reasons for this contention. First, other barriers in place such as political risk and capital controls may still serve to offset any benefit that results from adopting IFRS. Second, adoption of IFRS may not be perceived as a sufficient commitment to provide high quality and comparable financial reporting as firms can just adopt the label of IFRS without materially changing their reporting practice (Daske et al. 2013). Thirdly, although prior studies have documented that mandatory IFRS adoption led to increases in institutional ownership and foreign investment (DeFond et al. 2011; Florou and Pope 2012; Yu and Wahid 2014), there is no guarantee that the increase in foreign investment resulting from IFRS adoption improves financial integration. As mentioned earlier, the increases in foreign investment following IFRS adoption appear to be small in magnitude. It is unclear whether a small increase in foreign ownership can effectively improve financial integration. In addition, prior research suggests that other significant economic events that likely have a more profound effect on foreign investment and international trade do not necessarily affect financial integration. For example, Bekaert et al. (2013) show that the adoption of the Euro in a number of European countries did not result in greater financial integration despite the adoption removing the risk and transaction costs associated with currencies in the Euro zone.

We consider two aspects of financial integration. One is the extent to which local stock returns are driven by global information. Research on financial integration often posits that equity returns reflect local and global risk factors (Lewis 2011), and financial integration refers to the relative roles of global and local risk factors in determining expected returns. For instance, Stulz (1981) considers a perfectly integrated setting and links the equity risk premium strictly to the covariance with global risk factors. Bekaert and Harvey (1995) hold the same view that in completely integrated markets stock returns are driven solely by global risk factors. In less than perfectly integrated markets, Errunza and Losq (1985) point to the effect of both local and global factors on expected returns. Pukthuanthong and 
Roll (2009) propose that countries are more integrated if their stock returns are more subject to the global factors. Therefore, greater financial integration implies greater impact of global factors, relative to local factors, on expected stock returns. To the extent that IFRS adoption facilitates financial integration, it leads to our first testable hypothesis (in the alternative form):

H1: Mandatory IFRS adoption increases the extent to which local stock returns are driven by global risk factors.

The other aspect of financial integration is improved stock price efficiency in terms of the timeliness with which global news is incorporated into stock prices. The intuition here is that financial integration facilitates the cross-market transmission of value relevant information, so that global information is incorporated in local prices without delay. Bae et al. (2012) argue and find that removing foreign investment restrictions attracts global investors who are better at collecting and processing global news, and thus positively impacts the speed at which global news is incorporated into stock prices. Wang (2014) shows that after IFRS adoption, local stock prices react more strongly to earnings announcements by foreign firms that also use IFRS for financial reporting. The evidence suggests that IFRS adoption facilitates the transmission of earnings news across markets. To the extent that mandatory IFRS adoption reduces information frictions, it leads to the following testable hypothesis (in the alternative form):

H2: IFRS adoption improves the speed with which global news is incorporated into stock prices.

\section{Sample, empirical model, and variable construction}

Our initial sample selection starts with firm-level data from the countries included in the Compustat Global database for which we have information available on the accounting standards classification (data item "astd") and daily prices. Among the countries, 18 countries initiated mandatory adoption of IFRS in $2005 .{ }^{8}$ We restrict the adoption year to 2005 so that we can use the same

\footnotetext{
${ }^{8}$ Prior studies often list Hong Kong and Switzerland as adopting countries, but they did not mandate IFRS for domestically listed firms despite the widespread use of IFRS (Nobes and Zeff 2016). Our sample excludes firms from these two markets, although including them does not change our results.
} 
pre-period (years 2003 to 2004) and post-period (years 2006 to 2007) for all sample firms. ${ }^{9}$ This requirement removes Singapore from our sample due to its early mandatory IFRS adoption in 2003. For each of the IFRS-adopting countries, we define mandatory adopters as firms that used local GAAP before 2005 and switched to IFRS after $2005^{10}$ (i.e., firms whose astd is equal to "DS" in the pre-period and "DI" in the post-period). ${ }^{11}$ We then combine the remaining countries covered in Compustat Global with the US and Canadian firms covered in Compustat North America to form our control sample of non-IFRS countries, i.e., countries that did not require IFRS adoption (i.e., astd is equal to "DS," or "US" for US firms, throughout our sample period).

Finally, we remove the Philippines from the group of mandatory IFRS adoption countries and Russia from the group of non-IFRS countries because each has only two firms identified as mandatory or non-adopters. ${ }^{12}$ Another non-adopting market, Taiwan, is dropped from the sample because we cannot obtain country-level control variables from the World Bank database. To ensure the results are not due to different sample composition in the pre- and post-periods, we require each firm to have four full years of data. This leaves a final sample consisting of 9,148 firm-year observations of mandatory adopters from 17 mandatory IFRS adopter countries, and 42,280 firm-year observations of non-adopters from 17 non-IFRS adopter countries.

\section{Dependent variables: Measures of financial integration}

We measure two firm-level implications of financial integration developed in the extant finance literature. Our first measure is the extent to which a firm's stock returns are explained by global information. International finance literature typically assumes that local stock returns are driven by local

\footnotetext{
${ }^{9}$ We exclude year 2005 from our analyses to avoid the potential for confounding effects in the transition year. The post-period ends in 2007 to avoid any potential effects of the financial crisis in 2008.

${ }^{10}$ European Commission mandated IFRS for financial reporting starting with fiscal years beginning on or after January 1, 2005. This means that a firm could effectively initiate IFRS adoption in fiscal year 2006 if its fiscal year 2005 began before January 1, 2005. Furthermore, a few adopting countries allowed smaller firms to delay IFRS adoption until 2006. Our sample includes these "late adopters", but excluding the "late adopters" from the sample does not alter our results and inferences. It is also worth noting that, due to various exemptions and deferrals, a substantial portion of firms in the European Union did not adopt IFRS for financial reporting until 2009 (Pownall and Wieczynska 2017). Our sample of interest thus is the firms that started using IFRS in 2005 or 2006, rather than all firms in IFRS adopting countries.

11 "DS" stands for "Domestic Standards" and "DI" indicates domestic standards generally in accordance with or fully compliant with International Financial Reporting Standards (IFRS). We also cross check the accounting standards classification with the data item "IFRS" in the Datastream database. Whenever there is a conflict between the two databases, we exclude the observation.

${ }^{12}$ Including these two countries does not alter our findings.
} 
factors and global factors. In the absence of financial integration, local factors determine local stock returns with little role played by global factors. In the presence of complete financial integration, the "relevant source of systematic risk becomes the world market" (Chari and Henry 2004), and local prices are determined by the securities' exposure to global risk factors. Therefore, improvements in financial integration should increase the extent to which a stock's returns are tied to the global rather than to the domestic market portfolio (Gultekin et al. 1989; Korajczyk and Vialet 1989; Errunza et al. 1992; Chari and Henry 2004). Pukthuanthong and Roll $(2009,214)$ argue that "A sensible intuitive quantitative measure of financial market integration is the proportion of a country's returns that can be explained by global factors." In light of this argument, we measure the extent to which a stock is integrated into global markets by the proportion of its stock returns that can be explained by global returns, scaled by the portion that can be explained by both local and global returns. Specifically, we estimate the following time-series equation for each stock using its weekly stock returns across a year:

$$
R_{i, t}=\alpha+\sum_{k=0}^{3} \delta_{i, k} R_{g, t-k}+\sum_{k=0}^{3} \gamma_{i, k} R_{l, t-k}+\varepsilon_{i, t}
$$

where $R_{i, t}$ denotes the return on stock $i$ in week $t$, and $R_{g, t-k}$ and $R_{l, t-k}$ are the contemporaneous and lagged weekly returns on the global market portfolio and the local market portfolio, respectively, for $k$ $=0,1,2,3$. The local market returns and global market returns are measured by the weekly returns of the Morgan Stanley Capital International (MSCI) Country Index and the MSCI World Index from Datastream. $^{13}$

We label R-squares from regression (1) as $R^{2} \_$total. We then re-estimate the model by excluding local market portfolio returns:

$$
R_{i, t}=\alpha+\sum_{k=0}^{3} \delta_{i, k} R_{g, t-k}+\varepsilon_{i, t}
$$

The R-squares from this restricted model are denoted as $R^{2} \_$global. Our firm-specific measure of financial integration (INTEGRATE) is the ratio of $R^{2} \_$global to $R^{2} \_$total.

\footnotetext{
${ }^{13}$ The choice of weekly returns follows Bae et al. (2012) to minimize the effect of potential biases associated with nonsynchronous trading. The weekly returns are computed as compounded returns from Wednesday to Tuesday, to avoid a possible weekend effect. To mitigate the effect of data errors and extreme values, we delete weekly returns at the top and bottom $1 \%$ of their distributions. We require at least 20 weekly observations to be available for each stock in each year.
} 
We note that Equation (1) essentially assumes that stock returns are driven by a local factor and a global factor, as well as by their lags. $R_{-}^{2}$ total captures the explanatory power of these systematic factors, while $R^{2} \_$global captures the explanatory power of the global factor. ${ }^{14}$ The ratio of $R^{2} \_$global to $R^{2} \_$total thus measures the relative explanatory power of the global factor. The higher the ratio, the greater the influence of the global factor on firm-specific stock returns, and therefore the greater the level of financial integration of the underlying market involved.

Our second measure of financial integration, the speed with which local stock prices include global information, is related to the theoretical argument that greater financial integration produces more efficient stock prices. It is also based on Equation (1). In a well-integrated market with little friction, stock prices are expected to react to global information without delay. Following Bae et al. (2012), we estimate a restricted version of Equation (1) by setting the coefficients of lagged global portfolio returns at zero:

$$
R_{i, t}=\alpha+\delta_{i, t} R_{g, t}+\sum_{k=0}^{3} \gamma_{i, k} R_{l, t-k}+\varepsilon_{i, t}
$$

Bae et al. (2012) propose that the delay with which stock prices incorporate global information can be measured by the proportion of stock returns that is explained by lagged global portfolio returns. Specifically, their delay measure (Delay) is calculated as one minus the ratio of R-squared from Equation (3), $R_{\_}^{2} g r$, to R-squared from Equation (1), $R^{2} \_t o t a l$. We define SPEED as (1 - Delay), or simply $\frac{R_{-g r}^{2}}{R_{-t o t a l}^{2}}$. In a more integrated market, global information is incorporated into stock prices at a faster pace, so lagged global returns will explain a relatively smaller proportion of stock returns, resulting in higher values for our SPEED variable.

\section{Regression models}

To test our hypothesis that mandatory IFRS adoption facilitates financial integration, we take a difference-in-difference approach where the mandatory adopters form the test group and the non-IFRS adopters serve as the control group. In particular, we estimate the following equation:

$$
D E P_{i, t}=\beta_{0}+\beta_{1} \text { Mandatory }_{i, t}+\beta_{2} \text { Post }_{i, t}+\beta_{3} \text { Mandatory }_{i, t} \times \text { Post }_{i, t}+\text { Control }_{i, t-1}+\varepsilon_{i, t}
$$

\footnotetext{
14 Table A1 in the online Appendix reports the mean $R^{2} \_$total and $R^{2} \_$global for each country.
} 
where the dependent variables $(D E P)$ are the measures of financial integration (INTEGRATE and $S P E E D)$ for firm $i$ in year $t$, as defined previously. Mandatory is an indicator variable that equals one for firms in countries that had undertaken mandatory adoption of IFRS in 2005, and zero for firms from the control group of non-IFRS countries. Post is an indicator variable that equals one for observations in the post-mandatory IFRS adoption years (2006 and 2007), and zero for observations in the preadoption period (2003 and 2004). Our variable of interest is the interaction term, Mandatory $y_{i, t} \times$ Post $_{i, t}$, which captures the changes in financial integration due to mandatory IFRS adoption, benchmarked against changes in financial integration that arise in the control group (i.e., non-adopters). The coefficient on this interaction variable is depicted as follows: $\beta_{3}=\mathrm{E}\left(D E P\right.$ of treatment group ${ }_{\text {post }}-$ $D E P$ of treatment group $\left.{ }_{p r e}\right)-\mathrm{E}\left(D E P\right.$ of control group ${ }_{\text {post }}-D E P$ of control group $\left.{ }_{\text {pre }}\right)$. If mandatory IFRS adoption improves financial integration, we expect a positive value for $\beta_{3}$ for both measures of financial integration (INTEGRATE and SPEED).

Extant literature identifies several factors that may impact financial integration. Hou and Moskowitz (2005) suggest that investor attention and liquidity affect how actively investors engage in information searching and trading, so we control for these two factors by including measures of firm size (Size), share turnover (Turnover), return volatility (Volatility), analyst coverage (AnalystCover), and trading activity (TradingDay) in our empirical model. Size is measured by the natural logarithm of market value of equity. Turnover is measured as the weekly average of trading volume divided by the total number of shares outstanding. Volatility is measured by the standard deviation of weekly stock returns. AnalystCover is an indicator variable equal to one if at least one analyst issues annual earnings forecasts for the firm, and TradingDay measures the number of days the stock is actively traded. Further, we include an indicator variable (Loss) for firms reporting negative operating income to control for the differential pricing process for loss firms (Callen, Khan and Lu 2013). Finally, we control for investor recognition by including two indicator variables, IndexStock which indicates membership of MSCI Country Index, and $A D R$ which indicates American Depositary Receipt (ADR) stock. In addition to the above firm-level controls, we also consider country-level control variables. GDP is the natural logarithm of Gross Domestic Product (GDP); MktCap_GDP is the ratio of the country's total market 
capitalization to GDP; GDPGrowth is the growth rate of GDP; and Trade is the country's total amount of exports plus imports, scaled by the country's GDP. The definitions and data sources for all variables are provided in the Appendix.

The control variables are measured in year $t-1$ to minimize potential endogeneity concerns. As suggested in Hou and Moskowitz (2005) and Callen et al. (2013), we expect a negative coefficient for the variable Loss and positive coefficients for the other control variables. To control for systematic variation across industries, we include industry fixed effects in all regressions where an industry is defined on the basis of the one-digit Standard Industry Code. We estimate Equation (4) using OLS regressions and adjust standard errors for clustering at the firm level.

\section{Descriptive statistics}

Table 1 reports the distribution of mandatory adopters in adopting countries, and non-IFRS adopters in non-adopting countries. For our sample of mandatory adopters, while the number of unique firms and firm-year observations varies substantially across countries, the pattern is similar to that revealed in other studies. For example, our mandatory adopters sample shows that the United Kindom has the highest number of firm-year observations $(2,336)$, and Austria has the lowest number of observations (36). The non-adopter sample also shows a large range of variation across countries, with the US (17,808 firm-year observations) representing $42 \%$ of the sample and Peru having the lowest number of firm-year observations (24).

\section{[Insert Table 1 Here]}

Panel A and B in Table 2 present the descriptive statistics for financial integration measures and control variables for each type of firm in the pre- and post-adoption periods. The mandatory adopters have a higher mean value of INTEGRATE than the non-adopters. This evidence suggests that relative to non-adopters, adopters of IFRS tend to have stock returns that are more influenced by global factors. SPEED for mandatory adopters appears to be slightly lower than SPEED for non-adopters, suggesting that on average stock prices of IFRS adopters have a more delayed reaction to global information than that of non-adopters. This pattern is consistent in both pre- and post-adoption periods, and the contrast between INTEGRATE and SPEED suggests these two variables capture different aspects of financial integration. 
There are also significant differences in firm characteristics between the mandatory adopters and non-adopters. Relative to mandatory adopters, non-adopters are larger and have more loss-making years, higher share turnover, more volatility in stock returns, and lower likelihood to be followed by analysts. Voluntary adopters tend to be larger and have more analyst coverage than mandatory adopters. Again, these characteristics are consistent with those documented in prior studies (e.g., Daske et al. 2008; Byard et al. 2011). These differences suggest the importance of multivariate analysis where we control for factors that also contribute to the difference in financial integration across groups.

[Insert Table 2 Here]

Table 3 reports the Pearson and Spearman correlation coefficients between the variables. As expected, INTEGRATE and SPEED are positively correlated, with a Pearson correlation coefficient of 0.273 and a Spearman correlation coefficient of 0.257 , both of which are statistically significant at the $5 \%$ level. Both INTEGRATE and SPEED are positively related to stock turnover, the number of trading days, analyst coverage, inclusion in market indexes, and cross listing status, consistent with the expectation that better liquidity, information environment and international visibility facilitate the incorporation of global information into local prices. Stock return volatility and accounting loss are negatively related to both measures of financial integration. However, while INTEGRATE is negatively associated with firm size, GDP growth and foreign trade, SPEED is positive related to these variables. The evidence suggests that the two measures of financial integration are positively related but capture different dimensions of financial integration.

[Insert Table 3 Here]

\section{Empirical results}

\section{Univariate tests}

We begin our analysis with a univariate test comparing the means of the integration measures before and after 2005 for mandatory IFRS adopters and non-adopters. The results, reported in Table A2 in the online Appendix, show that mandatory adopters experience an increase of $0.061(=0.652-0.591)$ in INTEGRATE after 2005 while non-adopters had an increase of $0.017(=0.555-0.538)$. This suggests that both groups of firms display greater stock price sensitivity to global factors over time. In light of 
prior research, this finding is not surprising since there is a global move towards easing the restrictions on capital flows. Although both increases are statistically significant, the increase in INTEGRATE for mandatory adopters is over three times greater than that of non-adopters, and the difference between these two groups $(0.044)$ is statistically significant at the $1 \%$ level. This is similar for SPEED: both mandatory adopters and non-adopters experienced an increase in SPEED, which suggests that stock prices of both groups of firms respond in a more timely manner to global information after 2005 than before. But the increase in SPEED for mandatory adopters (0.036) is double that of non-adopters (0.017). The difference between these two groups (0.019) is also statistically significant at the $1 \%$ level.

The results from univariate tests are consistent with the hypotheses that mandatory IFRS adoption contributes to greater financial integration. Nevertheless, the improvement in integration of non-adopters suggests that changes besides IFRS adoption also contribute to financial integration. Hence, we conduct multivariate analysis to better isolate the effects of mandatory IFRS adoption on financial integration.

\section{Multivariate analyses of mandatory adopters and non-adopters}

Table 4 reports the multivariate regression results involving measures of financial integration. Columns (1) to (3) report the results where the dependent variable is INTEGRATE. Column (1) provides a baseline model where we regress INTEGRATE, Post, the interaction term Mandatory $\times$ Post, and industry fixed effects. Our primary variable of interest is the interaction term Mandatory $\times$ Post.

In Column (1), the coefficient of the interaction term, $\beta_{3}$, is positive and statistically significant (coefficient=0.047, $p$-value $<0.001$ ). This suggests that relative to non-adopters, mandatory adopters experienced a larger increase in INTEGRATE. These results are quite similar to those from univariate tests in Table 3 and consistent with hypothesis 1. Column (2) adds variables to control for firm characteristics related to financial integration and country fixed effects to control for any potential omitted country-level variables. The coefficient on the interaction term Mandatory $\times$ Post continues to be significantly positive (coefficient $=0.032, p$-value $<0.001$ ), which suggests that the incremental positive impact of mandatory IFRS adoption on INTEGRATE is not due to changes in firm characteristics or omitted country-level factors. Column (3) includes control variables for firm characteristics and replaces the country fixed effects with time varying country-level variables including 
a country's GDP, GDP growth rates, financial development, and international trade. The coefficient on the interaction term Mandatory $\times$ Post remains positive (0.031) and statistically significant at the $1 \%$ level. ${ }^{15}$

Columns (4) to (6) report the regression results where the dependent variable is SPEED. The coefficient on the interaction term Mandatory $\times$ Post is positive (0.023) in Column (4) and significant at the $1 \%$ level, suggesting that relative to non-adopters, mandatory adopters experienced a larger increase in the speed with which global information is incorporated into stock prices after 2005 . We obtain similar results in Column (5) where we add country fixed effects, and in Column (6) where we include control variables involving firm and country attributes.

In sum, the results in Table 4 support our hypotheses: relative to non-adopters, mandatory IFRS adopters experienced a larger improvement in financial integration. This finding suggests that IFRS adoption increased the degree to which local prices are driven by global information. IFRS adoption also led to higher stock price efficiency and timeliness in the recognition of global information in stock prices. These results hold after we control for industry fixed effects and various firm and country characteristics.

Given the way that financial integration is measured by INTEGRATE and SPEED, it is difficult to assess the economic significance of the increase in financial integration. However, a comparison between mandatory adopters and non-adopters indicates the relative significance of the effect of IFRS adoption on financial integration. Take Column (4) as an example. After controlling for firm characteristics and country fixed effects, the coefficient on Post $(0.029, p$-value $<0.001)$ suggests that for non-adopters, the increase in the speed at which global information is incorporated into their stock returns after 2005 is 0.029 . Mandatory adopters experienced an improvement of $0.046(=0.029+0.017)$ in SPEED, representing a $6.2 \%$ increase in the speed of global information being incorporated into

\footnotetext{
${ }^{15}$ Note the dependent variable in Columns 1 to 3, INTEGRATE, is the ratio of the R-squared from Equation (2), $R_{-}^{2}$ global, to the R-squared from Equation (1), $R_{-}^{2}$ total. One concern is that the observed increase in INTEGRATE is not due to an increase in $R_{-}^{2}$ global, but due to a decrease in the denominator $R^{2} \_$total. In untabulated results, we find the $R^{2} \_$total does not decrease during our sample period. Actually, relative to non-adopters, mandatory adopters experienced a significant increase in $R^{2}$ total after 2005, suggesting our results are not driven by a decrease in the denominator of INTEGRATE.
} 
mandatory adopters' stock prices. ${ }^{16}$ For comparison, Bae et al. (2012) examine the effect of restrictions on foreign investment in emerging markets on the speed of price adjustment to global information. Their estimates (Table 4, p217) show that SPEED improves by $18.5 \%$ if the proportion of shares that can be invested by foreigners increase by $91 \% .^{17}$ The relative magnitudes involved here suggest that the adoption of IFRS had an economically significant impact on financial integration.

[Insert Table 4 Here]

We conduct a number of robustness tests to ensure that our results in Table 4 are not driven by a few specific countries in the sample. The sample distribution in Table 1 shows that US firms dominate the non-adopter sample, accounting for $42 \%$ of non-adopter observations. One concern is whether our results are sensitive to the use of the US as a benchmark non-adopting country. To address this concern, we divide non-adopters into two groups - US firms and non-US firms, and compare mandatory adopters to these two groups separately. The results reported Table A3 in the online Appendix show that the finding of IFRS adoption associated with increased financial integration holds when we use either the US-only firms as the control group or all other non-adopters as the control group. ${ }^{18}$ In further robustness tests, we show that the results in Table 4 remain unchanged if we exclude China and New Zealand from the non-adopters sample since these two countries had significant convergence of local GAAP toward IFRS in the mid 2000s, or if we restrict the adopting countries to those located in Europe or members of the European Union. Results from these two robustness tests are reported in Tables A4 and A5 in the online Appendix, respectively. Hence, the results from robustness tests verify that the increase in financial integration is not sensitive to the choice of control group or treatment groups.

\section{Cross-sectional variation among the adopting countries}

\footnotetext{
16 This is calculated as 0.046 (the sum of the coefficients of Post and Mandatory $\times$ Post) divided by 0.741 (the mean SPEED for mandatory adopters in the pre IFRS adoption period, as reported in Panel A Table 2).

${ }^{17}$ Bae et al. (2012) show that one standard deviation increase in investible weight is associated with a decrease of $18.5 \%$ in a measure of price delay. One standard deviation increase, or 0.384 , is equivalent to $91 \%$ in the mean investible weight since the mean is 0.42 as shown in their Table 2.

${ }^{18}$ Alternatively, we follow prior research such as Dittmar et al. (2003) and estimate a weighted least squares (WLS) model where each observation is weighted by the inverse of the number of observations in each country. This ensures that each country receives equal weight in the estimation. Our results in Table 4 continue to hold in all the WLS regressions.
} 
In this section, we focus on the mandatory adopting countries and examine whether the association between financial integration and IFRS adoption varies with institutional factors, change in foreign investment, and improvement in accounting comparability in the direction as predicted. This exercise helps to attribute the observed increase in financial integration to IFRS adoption. In particular, we conjecture that mandatory IFRS adoption is likely to facilitate financial integration through two related channels. First, IFRS adoption facilitates cross-border transmission of global information by harmonizing accounting standards (Wang 2014). Second, IFRS adoption attracts more foreign investors who are better able to incorporate global information into local prices (DeFond et al. 2011; Bae et al. 2012). For the first channel, we expect that countries and firms that benefit most from the harmonization of accounting standards will have a larger improvement in financial integration. For the second channel, we predict that mandatory adopters that experience a larger increase in foreign ownership will have a larger improvement in financial integration.

To test these predictions, we construct measures of accounting comparability and collect data on foreign ownership. We then divide mandatory adopters into two subsamples based on the changes in accounting comparability and changes in foreign ownership. For each subsample, we estimate the following regression:

$$
D E P_{i, t}=\beta_{0}+\beta_{1} \text { Post }_{i, t}+\text { Control }_{i, t-1}+\varepsilon_{i, t}
$$

where DEP is either INTEGRATE or SPEED. The variable of interest is Post, which indicates the improvement in financial integration after mandatory adoption of IFRS in the subsamples.

\section{Analysis of accounting comparability}

We start with examining the effect of accounting harmonization on financial integration. Following DeFond et al. (2011) and Wang (2014), our measure of the degree of accounting harmonization is the difference between IFRS and local GAAP. A larger difference indicates the mandatory adopters experience a larger improvement in the comparability of their accounting numbers and benefit more from accounting harmonization. From Bae et al. (2008), we obtain a measure of the 
extent to which IFRS differs from local GAAP, which is the number of differences between IFRS and local GAAP on the accounting treatment of 21 items. $^{19}$

We partition the mandatory adopting countries into two groups based on whether their GAAP differences are above (Large) or below (Small) the sample median. Table 5 reports the results from regressions using mandatory adopters in each subsample. In Column (1), we find a significant increase in INTEGRATE for the Large GAAP Difference subsample $\left(\beta_{1}=0.040, p\right.$-value $\left.<0.001\right)$. Column (2) shows that the increase in INTEGRATE is statistically insignificant for the Small GAAP Difference subsample $\left(\beta_{1}=0.001, p\right.$-value $\left.=0.884\right)$. The difference in $\beta_{1}$ is statistically significant at the $1 \%$ level. ${ }^{20}$ We find similar evidence for SPEED in Columns (3) and (4). This result suggests that the impact of mandatory IFRS adoption on financial integration is greater in countries where there is a large difference between local GAAP and IFRS, consistent with our prediction.

[Insert Table 5 Here]

An issue in the mandatory IFRS adoption literature is whether firms truthfully adopt IFRS or only adopt the label of IFRS without changing their accounting practice (Daske et al. 2013). DeFond et al. (2011) argue that firms are more likely to truthfully implement IFRS in countries with a stronger legal system and law enforcement. Following this argument, we use the accounting enforcement index compiled by Brown, Preiato and Tarca (2014) to capture a country's strength in enforcement of IFRS in local markets. We combine GAAP Differences and accounting enforcement index to identify the countries that are most likely to benefit from a credible IFRS adoption. In particular, we follow DeFond et al. (2015) and classify mandatory IFRS adopter countries into two groups. The first group, labeled as "Strong", includes countries that have above-median accounting enforcement and above-median difference between local GAAP and IFRS. All other adopting countries are classified into the second group, which we label "Others". We then estimate Equation (6) separately for each group. The results, reported in Table A7 in the online Appendix, show that in both regressions using INTEGRATE and

\footnotetext{
${ }^{19}$ Table A6 in the online Appendix reports the GAAP differences and accounting enforcement index for each country in the sample.

${ }^{20}$ To test whether the coefficients are statistically significant, we combine the samples of the two groups and include an interaction between Post and GAAP difference in regressions. The interaction term captures the difference in the coefficients of Post for the two groups. The $p$-value for the difference in $\beta_{1}$ reported in Table 6 is based on the coefficient and standard errors of this interaction term.
} 
SPEED as the dependent variables the coefficients of Post are larger in the "Strong" group than those in the "Others" group. The difference in coefficients for these two groups is statistically significant, suggesting that the mandatory adopters located in countries with large differences between local GAAP and IFRS that can credibly implement IFRS experienced a larger improvement in financial integration.

We also use an alternative measure of accounting comparability to provide further support to the prediction. Following De Franco et al. (2011) and Yip and Young (2012), we measure accounting comparability based on the average absolute value of the difference between a firm's expected earnings using the accounting function in its own industry and home country and the expected earnings using the accounting function in the same industry but from foreign countries. As a first step, we estimate the following regression for each country-industry-year: $R O A_{\mathrm{i}, \mathrm{j}, \mathrm{k}, \mathrm{t}}=\alpha_{\mathrm{j}, \mathrm{k}, \mathrm{t}}+\beta_{\mathrm{j}, \mathrm{k}, \mathrm{t}} R E T_{\mathrm{i}, \mathrm{j}, \mathrm{k}, \mathrm{t}}+\varepsilon_{\mathrm{i}, \mathrm{j}, \mathrm{k}, \mathrm{t}}$, where $R O A$ is the income before extraordinary items divided by total assets, RET is the annual stock returns, and subscripts $i, j, k, t$ indicate firm, industry, country and year, respectively. The expected earnings using a firm's home country accounting function is the predicted value from the regression: $\mathrm{E}_{\mathrm{k}}(R O A)=\alpha_{\mathrm{j}, \mathrm{k}, \mathrm{t}}$ $+\beta_{\mathrm{j}, \mathrm{k}, \mathrm{t}} R E T_{\mathrm{i}, \mathrm{j}, \mathrm{k}, \mathrm{t}}$ Then for each industry-country-year combination, we use all the firms in the same industry but located in foreign countries to estimate the regression $R O A_{\mathrm{m}, \mathrm{j}, \mathrm{t}, \mathrm{t}}=\gamma_{\mathrm{j}, \mathrm{k}, \mathrm{t}}+\delta_{\mathrm{j}, \mathrm{n}, \mathrm{t}} R E T+\varepsilon_{\mathrm{m}, \mathrm{j}, \mathrm{n}, \mathrm{t}}$ The expected earnings using foreign countries' accounting function is $\mathrm{E}_{\mathrm{n}}(R O A)=\gamma_{\mathrm{j}, \mathrm{n}, \mathrm{t}}+\delta_{\mathrm{j}, \mathrm{n}, \mathrm{t}} R E T_{\mathrm{i}, \mathrm{j}, \mathrm{k}, \mathrm{t}}$. The average value of $\left|\mathrm{E}_{\mathrm{k}}(R O A)-\mathrm{E}_{\mathrm{n}}(R O A)\right|$ is used as a measure of accounting comparability, with small values indicating more comparable accounting systems. The improvements in accounting comparability in a country are then measured by taking the difference between the average accounting comparability in the pre-IFRS period and post-IFRS period. Unlike GAAP difference, this alternative measure is based on realized accounting numbers and thus presents an ex post measure of improvements in accounting comparability. We expect firms with large improvements in accounting comparability to have greater increase in financial integration.

We classify firms whose improvement in accounting comparability is above the top quartile in the sample as the large improvement group and leave other firms in the small improvement group. We then estimate Equation (6) separately for each group. Table 6 reports the results. Columns (1) and (2) show that both the large and small improvement groups experience a significant increase in INTEGRATE after IFRS adoption. However, the coefficient on the variable of interest, Post, for the 
large group (0.044) is larger than that of the small group (0.026). The difference in the coefficients is statistically significant ( $p$-value $=0.076$ ). In the regressions involving SPEED in Columns (3) and (4), the coefficient on Post for the large group is 0.029 ( $p$-value=0.016) but for the small group it is 0.006 ( $p$-value $=0.382)$. The difference between these two groups is significant at the $5 \%$ level $(p$-value $=0.023)$. The results show that the impact of IFRS adoption on financial integration is more pronounced when it is accompanied by large improvements in accounting comparability. This finding provides further support to our prediction that mandatory IFRS adoption improves financial integration by making accounting information more comparable and facilitating cross-border transmission of global information.

\section{[Insert Table 6 Here]}

\section{Analysis of change in foreign investment}

To examine whether IFRS adoption improves financial integration by attracting more foreign investors to local markets, we obtain firm-level foreign institutional ownership information from the FactSet database. We use these data to identify and measure the increases in foreign institutional ownership around the mandatory IFRS adoption. Specifically, for each mandatory adopter in the sample, we calculate the increases in foreign institutional ownership by using the mean foreign ownership in the post-IFRS period (2006 and 2007) minus the mean foreign ownership in the pre-IFRS period (2003 and 2004). We partition the mandatory adopters into two subsamples based on whether their increases in foreign institutional ownership are above (Large) or below (Small) the third quartile in the sample. Due to missing data on foreign institutional ownership, we have a reduced sample of 1,569 firm-year observations for this analysis. We expect firms that experienced large increases in foreign institutional ownership to have greater improvement in financial integration.

Columns (1) and (2) of Table 7 present the results of the regressions of INTEGRATE carried out separately for the subsamples. For both subsamples, the variable Post has a positive and significant coefficient. However, the coefficient is much larger in the subsample of firms with a large increase in foreign institutional ownership. The difference in the coefficients is statistically significant ( $p$ value $=0.035$ ), indicating that firms with a larger increase in foreign institutional ownership experienced a greater increase in INTEGRATE. Next, we turn to the regressions involving the other measure of 
financial integration, SPEED, in Columns (3) and (4) of Table 7. The results show that the coefficient on Post is positive for both subsamples, but it is statistically significant only for the subsample of firms with a large increase in foreign institutional ownership. The difference in the coefficients across the two subsamples is statistically significant, suggesting that individual stock returns incorporate global news in a more timely manner following IFRS adoption when IFRS adoption leads to a larger increase in foreign institutional ownership.

In sum, the results in Table 7 show that improvements in financial integration after IFRS adoption are more pronounced when adoption is accompanied by an increase in foreign investment. This evidence suggests that mandatory IFRS adoption facilitates financial integration by attracting foreign investors who are better able to incorporate global information into local stock prices.

\section{[Insert Table 7 Here]}

\section{Robustness checks}

To further evaluate the robustness of our findings, we run a range of additional analyses. This sub-section discusses the findings of these analyses with the results reported in the online Appendix.

\section{Effect of concurrent changes}

It has been noted that mandatory IFRS adoption is accompanied by some concurrent changes in the adopting countries, such as changes in legal enforcement and auditing standards. In particular, Christensen et al. (2013) examine and find that the effects of mandatory IFRS adoption on liquidity are more pronounced in countries which concurrently improved the legal enforcement of accounting practices, while the liquidity effects are absent in other countries. Their results suggest that the documented effects associated with IFRS adoption could be compounded by the concurrent changes in adopting countries. ${ }^{21}$ To address this concern, we conduct three additional tests. First, we examine whether the association between financial integration and mandatory IFRS adoption is impacted by

\footnotetext{
${ }^{21}$ We understand there is an ongoing debate on whether IFRS adoption per se can explain various effects of the adoption documented in the literature. Although it is not our intention to resolve the debate, we think it is important to consider more evidence from various settings and variables besides the liquidity effect that Christensen et al. (2013) examine. At the same time, we acknowledge that many institutional factors are interdependent and work together to shape the outcomes of financial reporting (Isidro, Nada and Wysocki 2016). IFRS adoption, together with accompanying institutional changes, can be perceived as a "package" that collectively influences adopting firms' integration into global markets.
} 
changes in the legal regime. We identify and distinguish observations from the five countries which experienced significant changes in the legal regime as identified by Christensen et al. (2013): Finland, Germany, Netherlands, Norway, and the United Kingdoms. The results, reported in Table A8 in the online Appendix, find mandatory IFRS adoption has a positive impact on financial integration in these five countries and in other adopting countries. We do not find a systematically stronger relation between financial integration and IFRS adoption in these five countries relative to other countries. The evidence suggests that the effect of IFRS adoption on financial integration is not confined to the five countries of concurrent law enforcement changes identified by Christensen et al. (2013).

Second, we examine the financial reforms taking place concurrently with mandatory IFRS adoption since financial reforms could make the local markets more integrated into global markets. In a robustness test, we control for the level of financial reforms surrounding the year 2005, using the financial reforms data constructed by Abiad et al. (2008). Results reported in Table A9 in the online Appendix show that our results remain unchanged after including of this additional control variable in the regression models.

Third, a few stock exchanges in European countries joined Euronext in early 2000s and in 2007 Euronext merged with New York Stock Exchange. Pownall et al. (2014) show that Euronext helped reduce frictions in stock trading and investors' home bias, potentially contributing to financial integration. To control for this concurrent change, we separate adopting countries into two groups based on whether their stock exchanges are a member of Euronext before 2005. We then re-estimate the main regression for each group and report the results in Table A10 in the online Appendix. The results show that, for both groups, the coefficients of the interaction term Mandatory $\times$ Post remain positive and statistically significant in regressions with INTEGRATE and SPEED as dependent variables. Our results hence suggest that IFRS adoption has an incremental effect on integration that is not subsumed by the formation of Euronext.

Within adopting country comparison: mandatory adopters vs. voluntary adopters

In some adopting countries, some firms voluntarily adopted IFRS or its predecessor IAS prior to 2005. The presence of these voluntary IFRS adopters allows us to examine whether mandatory IFRS adoption has an incremental effect on voluntary adopters in relation to financial integration. There are 
several reasons why an IFRS adoption mandate may also benefit these voluntary adopter firms. First, voluntary IFRS adoption may not be comprehensive since it is influenced by managerial discretion (Kim and Shi 2012). As a result, mandatory IFRS adoption may impact voluntary IFRS adopters insofar as it compels them to increase their commitment to complying with IFRS. Second, the rate of voluntary IFRS adoption is quite low (around 9\%, according to Kim and Shi 2012). In this instance, the passage of mandatory IFRS adoption can generate positive information-related externalities. Principally, mandatory IFRS adoption may serve to improve the comparability of the voluntary adopters to their peer firms. Again, the benefit is that mandatory IFRS adoption may positively affect the information environment of voluntary IFRS adopters.

We re-estimate Equation (4) using a sample of mandatory adopters and voluntary adopters and report the results in Table A11 in the online Appendix. The results of regressions using INTEGRATE as the dependent variable show that Post has a positive and statistically significant coefficient, suggesting that voluntary adopters experience a significant increase in INTEGRATE after mandatory IFRS adoption. The interaction term Mandatory $\times$ Post is statistically insignificant, suggesting that mandatory adopters experienced an increase in INTEGRATE similar to that of voluntary adopters. In regressions using SPEED as the dependent variable, Post has an insignificant coefficient, indicating that voluntary adopters did not experience an increase in SPEED. The interaction term has a positive and statistically significant coefficient, suggesting that mandatory adopters experienced a larger increase in the speed of pricing global information, relative to voluntary adopters. In sum, the above evidence suggests that both mandatory and voluntary adopters benefit from mandatory IFRS adoption. However, the impact appears to be more substantial for mandatory adopter firms. ${ }^{22}$

Time effect

The results reported earlier are based on the sample period of 2003 to 2004 and 2006 to 2007. A concern is whether our results merely reflect a time trend that is unrelated to mandatory IFRS

\footnotetext{
${ }^{22}$ This evidence also helps to address the concurrent institutional changes accompanying IFRS adoption in the adopting countries. To the extent these changes affect both voluntary and mandatory adopters in the same country, using voluntary adopters as a benchmark helps control for these concurrent changes.
} 
adoption. While the difference-in-difference design help address this concern, we conduct robustness tests to further alleviate the concern.

First, to allow for possible time trends in INTEGRATE and SPEED, we follow Landsman et al. (2012) and define a time-trend variable as year minus 2000. After controlling for this time-trend variable, we find no qualitative change in our results, reported in Table A12 in the online Appendix.

Second, we conduct placebo tests using pseudo-event years to evaluate whether similar results are obtained for these events as well. In particular, we choose an event year to replace 2005 and define the earlier (later) two years as the pre- (post-) period. For example, using the year 2003 as a pseudoevent year, we compare the years 2001 and 2002 against the years 2003 and 2004. If our findings are due to the 2005 IFRS adoption event, then we should not observe the same for these pseudo-event windows. The results from placebo tests are reported in Table A13 in the online Appendix. For the various pseudo-event years used, we fail to find a significant and positive coefficient on the variable of interest which is the interaction term Mandatory $\times$ Post. This finding further bolsters our evidence that mandatory IFRS adoption contributed to an increase in financial integration.

Alternative measurements of the financial integration variables: INTEGRATE and SPEED

As described earlier, our construction of the two financial integration measures, INTEGRATE and SPEED, involves the regression of a firm's stock returns on its local stock market index returns and global stock market index returns (see Equation (1)). The global stock market returns is based on the returns on the MSCI World Index. A criticism of the MSCI World Index is that it is heavily represented by a few large and developed countries (markets). To mitigate this concern, we use alternative global market indexes to re-estimate both INTEGRATE and SPEED. In contrast to the MSCI World Index which includes indexes from 23 developed countries, we use a more comprehensive global index MSCI All Country World Index which consists of 23 developed markets and 21 developing markets. This index reduces the concentration of large developed markets in the global index. We also use the MSCI World Index after excluding the US from the index. This removes the influence of the US on the MSCI World Index which may otherwise capture US information rather than global information. We also use two Europe-centric indexes - the MSCI European Index and the STOXX European Index. This again mitigates the concern of over-representation of the US in the global market index. Furthermore, 
a large number of countries in these indices undertook mandatory adoption of IFRS. The results, reported in Table A14 in the online Appendix, show that our results are robust to the use of these alternative global market indices.

\section{Other robustness checks}

Our sample construction relies on the Compustat Global database which tends to cover larger firms in fewer countries in comparison to the Worldscope database. This may make our sample distribution across countries not comparable to those reported in prior studies that use the Worldscope database. To check if our results are sensitive to the database coverage, we reconstruct our sample and redo the main tests using data from the Worldscope and Datastream databases. The results are reported in Table A15 in the online Appendix. We still find significantly positive coefficients on the variable of interest, Mandatory $\times$ Post, when compared with non-adopters or voluntary adopters, for both financial integration measures.

In our sample, there are a small number of firms listed in a foreign country. For these crosslisted firms, it is not easy to define the country or local market of these firms. Also, the prices of a crosslisted stock and the underlying shares may not be congruent. To ensure that this unique group of firms does not affect our results, we redo our analyses after removing the firms that are cross-listed in a foreign country. Our results, reported in Table A16 in the online Appendix, remain unchanged.

Some firms have operations in foreign countries, which may make their stock prices more integrated in the global market. We conduct two robustness tests to control for foreign operations. First, we add variables in regressions controlling for foreign operations, including foreign assets, foreign sales, foreign merger and acquisition activities and cross-listing. Second, we exclude firms with foreign assets or foreign sales and redo our analysis. The results, reported in Table A17 in the online Appendix, show that our main results remain unchanged in both robustness tests.

Our main results compare mandatory adopters with non-adopters. Since adopting countries are mostly developed markets while non-adopting countries are mostly developing markets, there is a concern that some non-adopters may not be appropriate benchmarks. This concern is partially addressed when we use only non-adopters in the US as a benchmark. Furthermore, we use propensity score matching to select a sample of non-adopters that have similar size, are in the same industry, and have a 
similar level of enforcement strength as mandatory adopters. Specifically, we select matched firms from the non-adopting countries that are in the same industry, are from a country with the closest enforcement strength and have similar size (as measured by market capitalization). ${ }^{23}$ Firms from the US represent the largest portion of the matched sample, followed by firms in Japan. This suggests that a mandatory adopter in the UK is more likely to be matched to a non-adopter in the US, rather than a non-adopter in Argentina. ${ }^{24}$ We re-estimate Equation (4) using the matched sample. The results, reported in Table A18 in the online Appendix, are similar to those reported in the paper.

Our dependent variables in Equation (4), INTEGRATE and SPEED, are bounded by 0 and 1. While our results from OLS regression are robust and consistent, we also use Tobit model to re-estimate Equation (4), and obtain similar results (reported in Table A19 in the online Appendix). In all regressions, we control for industry fixed effects and classify industry by one-digit standard industry classification codes. In a robustness test, we follow the classification of Fama-French 12 industries and redo the analysis. The results, reported in Table A20 in the online Appendix, remain unchanged.

\section{Conclusions}

A large number of studies in international finance have documented evidence that greater financial integration helps reduce the cost of capital and increase corporate investment and economic growth (Henry 2000a, 2000b; Bekaert and Harvey 2001). However, significant barriers that impede financial integration still exist and the global market is still far from full integration. One barrier is information frictions that discourage foreign investment and hamper capital mobility. In 2005, a number of countries adopted IFRS with the expectation that a uniform set of accounting standards to achieve accounting harmonization would make accounting numbers more comparable across markets and thus facilitate financial integration by reducing information frictions. We empirically evaluate this question by examining the effect of mandatory IFRS adoption on financial integration. We hypothesize that

\footnotetext{
${ }^{23}$ An advantage of this analysis is the parallel trends assumption underlying the difference-in-differences analysis is more defensible when the treatment and control firms more closely resemble one another.

${ }^{24}$ Examining the difference in law enforcement strength in the matched sample, we find that the mean of strength of law enforcement for the mandatory adopters is 1.381 , and the mean for the non-adopters is 1.379 . The difference in the mean is not statistically significant (t-stat. $=0.28$ ), so it appears that the matching does find mandatory adopters and voluntary adopters in countries with similar law enforcement strength.
} 
accounting standards harmonization facilitates financial integration by improving accounting comparability and reducing information costs. Following the concept of financial integration proposed by the extant literature, we construct empirical measures to capture two related but distinct aspects of financial integration. The first measure is the extent to which local stock returns can be explained by global factors, with a larger extent indicating greater integration. The second measure is the speed at which global information is incorporated into local stock returns, with a faster speed indicating greater integration. Our empirical tests use a difference-in-difference design and compare mandatory adopters with non-adopters and voluntary adopters.

Consistent with our hypotheses, we find that mandatory adopters experience a greater improvement in financial integration after adopting IFRS, relative to non-adopters. Specifically, we find that IFRS adoption positively impacts the proportion of stock return variation explained by global factors. IFRS adoption also increases the speed with which global news is incorporated into a firm's stock prices. Further, we find these effects of IFRS are more pronounced in countries with larger differences between IFRS and local GAAP, or in countries that experience a larger improvement in accounting comparability. The evidence suggests that IFRS adoption facilitates financial integration through improved accounting comparability that enhances cross-border information flow. We also find the impact of IFRS on financial integration to be more pronounced when it is accompanied by a greater increase in foreign ownership. This evidence suggests that increase in foreign investment and capital mobility is likely to be another channel through which IFRS adoption can facilitate financial integration.

Our study contributes to the literature on financial integration by showing that adopting a uniform set of accounting standards (i.e. accounting harmonization) improves financial integration by reducing information frictions. Our results shed light on regulatory efforts around the world to improve financial integration by removing various barriers that hinder full integration. In particular, our study supports the regulators' expectation that IFRS adoption helps improve financial integration.

Our results also contribute to the growing literature on the effect of IFRS adoption. Prior studies have documented that IFRS adoption has an impact on foreign ownership of local stocks. Our study takes one step further and shows that IFRS facilitates financial integration. Other studies find an impact of IFRS on the cost of capital and explain the lower cost of capital following IFRS adoption by the 
reduction of information asymmetry or the improvement in information quality. Our evidence suggests that another potential explanation for this finding is the improvement in risk sharing due to increased financial integration, as documented in the international finance literature. 


\section{References}

Abiad, A., E. Detragiache, and T. Tressel. 2008. A new database of financial reform. Working paper, International Monetary Fund.

Ahmed, A.S., M. Neel, and D. Wang. 2013. Does mandatory adoption of IFRS improve accounting quality? Preliminary evidence. Contemporary Accounting Research 30 (4): 1344-1372.

Amiram, D. 2012. Financial information globalization and foreign investment decisions. Journal of International Accounting Research 11 (2): 57-81.

Bae, K., A. Ozoguz, H. Tan, and T. Wirjanto. 2012. Do foreigners facilitate information transmission in emerging markets? Journal of Financial Economics 105: 209-227.

Bae, K., H. Tan, and M. Welker. 2008. International GAAP differences: The impact on foreign analysts. Accounting Review 83: 593-628.

Barth, M., W. R. Landsman, and M. Lang. 2008. International Accounting Standards and accounting quality. Journal of Accounting Research 46: 467-498.

Bekaert, G. 1995. Market integration and investment barriers in emerging equity markets. World Bank Economic Review 9: 75-107.

Bekaert, G., and C. R. Harvey. 1995. Time-varying world market integration. Journal of Finance 50: 403-44.

Bekaert, G., and C. R. Harvey. 2001. Economic growth and financial liberalization. Research Summary in the NBER Reporter, Spring 2001: 8-11.

Bekaert, G., C. R. Harvey, and R. Lumsdaine. 2002. Dating the integration of world capital markets. Journal of Financial Economics 65: 203-249.

Bekaert, G., C. R. Harvey, and C. T. Lundblad. 2003. Equity market liberalization in emerging markets. Journal of Financial Research 26: 275-299.

Bekaert, G., C. R. Harvey, C. Lundblad, and S. Siegel. 2011. What segments equity markets? Review of Financial Studies 24: 3841-3890.

Bekaert, G., C. R. Harvey, C. Lundblad, and S. Siegel. 2013. The European Union, the Euro, and equity market integration. Journal of Financial Economics 109: 583-603.

Beneish, M., B. Miller, and T. Yohn. 2009. The effect of IFRS adoption on cross-border investment in equity and debt markets. Working paper, Indiana University.

Brown, P., J. Preiato, and A. Tarca. 2014. Measuring country differences in enforcement of accounting standards: An audit and enforcement proxy. Journal of Business Finance and Accounting 41: $1-52$.

Bruggemann, U., H. Daske, C. Homburg, and P. Pope. 2009. How do individual investors react to global IFRS adoption? Working paper, Lancaster University, University of Mannheim, and University of Cologne.

Byard, D., Y. Li, and Y. Yu. 2011. The effect of mandatory IFRS adoption on financial analysts' information environment. Journal of Accounting Research 49: 69-96.

Callen, J., M. Khan, and H. Lu. 2013. Accounting quality, stock price delay and future stock returns. Contemporary Accounting Research 30 (1): 269-295.

Chari, A., and P. B. Henry. 2004. Risk sharing and asset prices: Evidence from a natural experiment. Journal of Finance 59 (3): 1295-1324.

Christensen, H. B., L. Hail, and C. Leuz. 2013. Mandatory IFRS reporting and changes in enforcement. Journal of Accounting and Economics 56: 147-177.

Chuhan, P. 1992. Sources of portfolio investment in emerging markets. World Bank Working Paper, International Department of Economics, Washington DC.

Covrig, V., M. DeFond, and M. Hung. 2007. Home bias, foreign mutual fund holdings, and the voluntary adoption of International Accounting Standards. Journal of Accounting Research 45: 41-70.

Daske, H., L. Hail, C. Leuz, and R. Verdi. 2008. Mandatory IFRS reporting around the world: Early evidence on the economic consequences. Journal of Accounting Research 46: 1085-1142.

Daske, H., L. Hail, C. Leuz, and R. Verdi. 2013. Adopting a label: Heterogeneity in the economic consequences around IAS/IFRS adoptions. Journal of Accounting Research 51 (3): 495-547. 
DeFond, M., X. Hu, M. Hung, and S. Li. 2011. The impact of mandatory IFRS adoption on foreign mutual fund ownership: The role of comparability. Journal of Accounting and Economics 51: 240-258.

DeFond, M., M. Hung, S. Li, and Y. Li. 2015. Does mandatory IFRS adoption affect crash risk? Accounting Review 90: 265-300.

De Franco, G., S. P. Kothari, and R. S. Verdi. 2011. The benefits of financial statement comparability. Journal of Accounting Research 49 (4): 895-931.

De George, E., X. Li, and L. Shivakumar. 2016. A review of the IFRS adoption literature. Review of Accounting Studies 21 (3): 898-1004.

Dittmar, A., J. Mahrt-Smith and H. Servaes. 2003. International corporate governance and corporate cash holdings. Journal of Financial and Quantitative Analysis 38: 111-133.

Errunza V., and E. Losq. 1985. International asset pricing under mild segmentation: Theory and test. Journal of Finance 40: 105-24.

Errunza, V., E. Losq, and P. Padmanabhan. 1992. Tests of integration, mild segmentation and segmentation hypotheses. Journal of Banking and Finance 16: 949-972.

Florou, A., and P. Pope. 2012. Mandatory IFRS adoption and institutional investment decisions. Accounting Review 87 (6): 1993-2025.

Francis, J., S. Huang, and I. Khurana. 2012, The role of international GAAP in cross-border mergers and acquisitions. Working paper, University of Missouri.

Giannetti, M., L. Guiso, T. Jappelli, M. Padula, and M. Pagano. 2002. Financial market integration, corporate financing and economic growth. European Commission Economic Papers No. 179. Available at http://ec.europa.eu/economy finance/publications/pages/publication1660 en.pdf.

Gordon, L., M. Loeb, and W. Zhu. 2012, The impact of IFRS adoption on foreign direct investment. Journal of Accounting and Public Policy 31 (4): 374-398.

Gultekin, M. N., N. B. Gultekin, and A. Penati. 1989. Capital controls and international capital market segmentation: The evidence from the Japanese and American stock markets. Journal of Finance 44 (4): 849-869.

Henry, P. B. 2000a. Stock market liberalization, economic reform, and emerging market equity prices. Journal of Finance 55 (2): 529-564.

Henry, P. B. 2000b. Do stock market liberalizations cause investment booms? Journal of Financial Economics 58: 301-334.

Henry, P. B. 2003. Capital-account liberalization, the cost of capital, and economic growth. American Economic Review 93: 91-96.

Horton, J., G. Serafeim, and I. Serafeim. 2013. Does mandatory IFRS adoption improve the information environment? Contemporary Accounting Research 30 (1): 388-423.

Hou, K., and T. J. Moskowitz. 2005. Market frictions, price delay, and the cross section of expected returns. Review of Financial Studies 18: 981-1020.

Isidro, H., D. Nanda, and P. Wysocki. 2016. Financial reporting differences around the world: What matters? Working paper, University of Miami.

Kalemli-Ozcan, S., S. Manganelli, E. Papaioannou, and J. L. Peydró. 2008. Financial integration and risk sharing: The role of the monetary union. Working paper, University of Houston and NBER.

Karolyi, G. A. 2003. Does international financial contagion really exist? International Finance 6 (2): 179-199.

Kaufmann, D., A. Kraay, and M. Mastruzzi. 2007. Governance matters VI: Aggregate and individual governance indicators 1996-2006. The World Bank, Washington, DC.

Kim, Y., and S. Li. 2011. The externality effect of accounting standards convergence: Evidence from cross-border information transfers around EU mandatory IFRS adoption. Working paper, Santa Clara University.

Kim, J.-B., and H. Shi. 2012. IFRS reporting, firm-specific information flows, and institutional environments: International evidence. Review of Accounting Studies 17: 474-517.

Korajczyk, R. A., and C. J. Vialet. 1989. An empirical investigation of international asset pricing. Review of Financial Studies 2 (4): 553-585. 
Lai, C., Y. Li, Y. Shan, and S. Taylor. 2013. Costs of mandatory international financial reporting standards: Evidence of reduced accrual reliability. Australian Journal of Management 38: 491-521.

Landsman, W., E. Maydew, and J. Thornock. 2012. The information content of annual earnings announcements and mandatory adoption of IFRS. Journal of Accounting and Economics 53 (1-2): 34-54.

Lantto, A.-M., and P. Sahlstrom. 2009. Impact of international financial reporting standard adoption on key financial ratios. Accounting and Finance 49: 341-361.

Lewis, K. K. 2011. Global asset pricing. Annual Review of Financial Economics 3: 435-466.

Li, S. 2010. Does mandatory adoption of International Financial Reporting Standards in the European Union reduce the cost of equity capital? Accounting Review 85: 607-636.

Louis, H., and O. Urcan. 2014. The effect of IFRS on cross-border acquisitions. Working paper, Pennsylvania State University.

Nobes, C. W., and S. A. Zeff. 2016. Have Canada, Japan and Switzerland adopted IFRS? Australian Accounting Review 26: 284-290.

Obstfeld, M., and A. Taylor. 2004. Global capital markets: integration, crisis, and growth. Cambridge University Press.

Pownall G., M. Vulcheva, and X. Wang. 2014. The ability of global stock exchange mechanisms to mitigate home bias: Evidence from Euronext. Management Science 60: 1655-1676.

Pownall, G., and M. Wieczynska. 2017. Deviations from the Mandatory Adoption of IFRS in the European Union: Implementation, Enforcement, Incentives, and Compliance. Working paper, available at SSRN: https://ssrn.com/abstract=1919805.

Pukthuanthong, K., and R. Roll. 2009. Global market integration: An alternative measure and its application. Journal of Financial Economics 94: 214-232.Stulz, R. M. 1981. A model of international asset pricing. Journal of Financial Economics 9: 383-406.

Stulz, R. M. 1981. A model of international asset pricing. Journal of Financial Economics 9: 383-406.

Stulz, R. M. 1999. Globalization, corporate finance and the cost of capital. Journal of Applied Corporate Finance 12 (3): 8-25.

Stulz, R. M. 2005. The limits of financial globalization. Journal of Finance 60: 1595-1638.

Tan, H., S. Wang, and M. Welker. 2011. Foreign analysts following and forecast accuracy around mandatory IFRS adoptions. Journal of Accounting Research 49 (5): 1307-1357.

Wang, C. 2014. Accounting standards harmonization and financial statement comparability: Evidence from transnational information transfer. Journal of Accounting Research 52: 955-992.

Yip, R., and D. Young. 2012. Does mandatory IFRS adoption improve information comparability? Accounting Review 87 (5): 1767-1789.

Yu, G., and A. S. Wahid. 2014. Accounting standards and international portfolio holdings. Accounting Review 89 (5): 1895-1930. 
Appendix: Variable Definitions

\begin{tabular}{ll} 
Variables & \multicolumn{1}{c}{ Definition } \\
\hline Dependent variables & \\
INTEGRATE & $\begin{array}{l}\text { A measure of financial integration based on the ratio of the } \\
\text { proportion of stock return variation explained by current and lagged } \\
\text { global market returns to the proportion of return variation that can be } \\
\text { explained by current and lagged global and local market returns. }\end{array}$
\end{tabular}

SPEED

A measure of speed at which stock prices respond to global market information, based on the ratio of the proportion of stock return variation explained by current global market returns and current and lagged local market returns to the proportion of return variation that can be explained by current and lagged global and local market returns.

Variables of interest

Mandatory

An indicator variable equal to 1 for mandatory adopters, and 0 otherwise. Mandatory adopters are firms located in adopting countries that mandated International Financial Reporting Standards in 2005. Mandatory adopters used local GAAP before 2005 and switched to IFRS after 2005 when the country mandated IFRS adoption.

Post An indicator variable equal to 1 for firm-year observations after 2005, and 0 otherwise.

\section{Control variables}

Size

Turnover

Volatility

TradingDay

Loss

AnalystCover

IndexStock

$A D R$

GDP

MktCap_GDP

GDPGrowth

Trade

Partition variables

GAAP difference

Accounting comparability
Natural $\log$ of a firm's market capitalization.

Average weekly trading volume divided by total number of shares outstanding.

Standard deviation of weekly stock returns in a year.

Natural $\log$ of the number of days in which a stock has positive trading volume in a year.

An indicator variable equal to 1 if a firm reports a negative operating income, and 0 otherwise.

An indicator variable equal to 1 if a firm received analyst coverage, and 0 otherwise.

An indicator variable equal to 1 if a firm is a member of MSCI country index, and 0 otherwise.

An indicator variable equal to 1 if a firm has an American depositary receipt (ADR), and 0 otherwise.

Natural log of a country's Gross Domestic Product.

The ratio of a country's total market capitalization to its Gross Domestic Product.

The annual growth rate (in percentage) of a country's Gross Domestic Product.

The sum of a country's imports and exports, deflated by GDP.

The number of major differences between local GAAP and IFRS, as compiled by Bae et al. (2008).

the average absolute value of the difference between a firm's expected earnings using accounting function in its own country and the expected earnings using accounting functions in other countries, following De Franco et al. (2009) and Yip and Young (2012).
Constructed from stock returns data in Compustat and market index data from Datastream Constructed from stock returns data in Compustat and market index data from Datastream

Constructed from accounting standards data in Compustat

Compustat

Compustat

Compustat

Compustat

Compustat

IBES

Datastream

Datastream

World Bank

World Bank

World Bank

World Bank

Bae et al. (2008)

Constructed from data in Compustat 
TABLE 1 Sample distribution by countries

This table reports sample distribution by country. Mandatory adopters are firms that switched from local GAAP to IFRS in 2005 or 2006 and are located in countries that mandated IFRS adoption in 2005. Non-adopters are firms that followed local GAAP from 2003 to 2007 and are located in countries that did not mandate IFRS in our sample period.

\begin{tabular}{|c|c|c|c|c|c|}
\hline \multicolumn{3}{|c|}{ Mandatory adopters } & \multicolumn{3}{|c|}{ Non-Adopters } \\
\hline $\begin{array}{l}\text { Adopting } \\
\text { Countries }\end{array}$ & $\begin{array}{l}\text { Unique } \\
\text { firms }\end{array}$ & $\begin{array}{c}\text { Firm-years } \\
(2003,2004 ; \\
2006,2007)\end{array}$ & $\begin{array}{l}\text { Non-Adopting } \\
\text { Countries }\end{array}$ & $\begin{array}{l}\text { Unique } \\
\text { firms }\end{array}$ & $\begin{array}{c}\text { Firm-years } \\
(2003,2004 \\
2006,2007)\end{array}$ \\
\hline Australia & 49 & 196 & Argentina & 34 & 136 \\
\hline Austria & 9 & 36 & Brazil & 91 & 364 \\
\hline Belgium & 58 & 232 & Canada & 150 & 600 \\
\hline Denmark & 78 & 312 & China & 293 & 1,172 \\
\hline Finland & 90 & 360 & India & 389 & 1,556 \\
\hline France & 353 & 1,412 & Indonesia & 138 & 552 \\
\hline Germany & 145 & 580 & Israel & 27 & 108 \\
\hline Greece & 74 & 296 & Japan & 3,113 & 12,452 \\
\hline Ireland & 27 & 108 & Malaysia & 597 & 2,388 \\
\hline Italy & 185 & 740 & Mexico & 37 & 148 \\
\hline Netherlands & 97 & 388 & New Zealand & 49 & 196 \\
\hline Norway & 85 & 340 & Pakistan & 58 & 232 \\
\hline Portugal & 30 & 120 & Peru & 6 & 24 \\
\hline South Africa & 152 & 608 & South Korea & 899 & 3,596 \\
\hline Spain & 79 & 316 & Thailand & 218 & 872 \\
\hline Sweden & 192 & 768 & Turkey & 19 & 76 \\
\hline United Kindom & 584 & 2,336 & USA & 4,452 & 17,808 \\
\hline Total & 2,287 & 9,148 & Total & 10,570 & 42,280 \\
\hline
\end{tabular}


TABLE 2 Descriptive statistics

This table reports descriptive statistics for sample firms. This table reports sample distribution by country. Mandatory adopters are firms that switched from local GAAP to IFRS in 2005 or 2006 and are located in countries that mandated IFRS adoption in 2005. Non-adopters are firms that followed local GAAP from 2003 to 2007 and are located in countries that did not mandate IFRS in our sample period. Refer to the Appendix for the definitions of all variables.

Panel A: Descriptive statistics in the pre-IFRS adoption period (2003 and 2004)

\begin{tabular}{lcccccc}
\hline & \multicolumn{2}{c}{ Mandatory Adopters $(\mathrm{N}=4,574)$} & \multicolumn{3}{c}{ Non-Adopters $(\mathrm{N}=21,140)$} \\
& Mean & Median & Std & Mean & Median & Std \\
\hline INTEGRATE & 0.591 & 0.616 & 0.225 & 0.538 & 0.539 & 0.239 \\
SPEED & 0.741 & 0.787 & 0.200 & 0.770 & 0.823 & 0.188 \\
Size & 19.073 & 18.917 & 2.095 & 20.946 & 21.268 & 3.270 \\
Turnover & 0.009 & 0.006 & 0.011 & 0.023 & 0.008 & 0.042 \\
Volatility & 0.053 & 0.049 & 0.023 & 0.074 & 0.063 & 0.043 \\
TradingDay & 5.301 & 5.505 & 0.485 & 5.299 & 5.493 & 0.534 \\
Loss & 0.207 & 0.000 & 0.406 & 0.257 & 0.000 & 0.437 \\
AnalystCover & 0.515 & 1.000 & 0.500 & 0.417 & 0.000 & 0.493 \\
IndexStock & 0.484 & 0.000 & 0.500 & 0.460 & 0.000 & 0.498 \\
ADR & 0.040 & 0.000 & 0.195 & 0.011 & 0.000 & 0.106 \\
GDP & 27.473 & 28.182 & 1.006 & 28.839 & 29.158 & 1.474 \\
MktCap_GDP & 0.936 & 0.901 & 0.403 & 0.994 & 0.850 & 0.374 \\
GDPGrowth & 2.494 & 2.949 & 1.424 & 3.533 & 2.744 & 2.003 \\
Trade & 0.651 & 0.538 & 0.234 & 0.435 & 0.247 & 0.444 \\
\hline
\end{tabular}

Panel B: Descriptive statistics in the post-IFRS adoption period (2006 and 2007)

\begin{tabular}{lcccccc}
\hline & \multicolumn{3}{c}{ Mandatory Adopters $(\mathrm{N}=4,574)$} & \multicolumn{3}{c}{ Non-Adopters $(\mathrm{N}=21,140)$} \\
& Mean & Median & Std & Mean & Median & Std \\
\hline INTEGRATE & 0.652 & 0.687 & 0.213 & 0.555 & 0.559 & 0.226 \\
SPEED & 0.777 & 0.835 & 0.189 & 0.787 & 0.841 & 0.182 \\
Size & 19.798 & 19.664 & 2.128 & 21.540 & 21.868 & 3.309 \\
Turnover & 0.014 & 0.009 & 0.017 & 0.029 & 0.014 & 0.044 \\
Volatility & 0.041 & 0.037 & 0.017 & 0.060 & 0.051 & 0.035 \\
TradingDay & 5.428 & 5.529 & 0.325 & 5.407 & 5.509 & 0.363 \\
Loss & 0.129 & 0.000 & 0.336 & 0.215 & 0.000 & 0.411 \\
AnalystCover & 0.627 & 1.000 & 0.484 & 0.440 & 0.000 & 0.496 \\
IndexStock & 0.484 & 0.000 & 0.500 & 0.460 & 0.000 & 0.498 \\
ADR & 0.036 & 0.000 & 0.185 & 0.011 & 0.000 & 0.102 \\
GDP & 27.734 & 28.386 & 0.978 & 29.032 & 29.108 & 1.375 \\
MktCap_GDP & 1.229 & 1.222 & 0.538 & 1.230 & 1.425 & 0.288 \\
GDPGrowth & 3.250 & 3.269 & 1.051 & 3.503 & 2.363 & 2.500 \\
Trade & 0.735 & 0.611 & 0.264 & 0.494 & 0.310 & 0.439 \\
\hline
\end{tabular}


TABLE 3 Correlation coefficients

This table reports the correlation coefficients between the variables used in multivariate analyses. Pearson correlation coefficients are reported below the diagonal while Spearman correlation coefficients are reported above the diagonal. All the coefficients are statistically significant at the $10 \%$ level or better, except those marked with ^.

\begin{tabular}{|c|c|c|c|c|c|c|c|c|c|c|c|c|c|c|}
\hline & $(1)$ & (2) & (3) & $(4)$ & $(5)$ & $(6)$ & $(7)$ & $(8)$ & $(9)$ & $(10)$ & $(11)$ & $(12)$ & $(13)$ & (14) \\
\hline (1)INTEGRATE & 1 & 0.257 & -0.054 & 0.193 & -0.057 & 0.343 & -0.031 & 0.207 & 0.149 & 0.048 & 0.231 & 0.179 & -0.103 & -0.088 \\
\hline (2)SPEED & 0.273 & 1 & 0.314 & 0.209 & -0.143 & 0.244 & -0.162 & 0.211 & 0.275 & 0.061 & -0.021 & -0.026 & 0.011 & 0.025 \\
\hline (3)Size & -0.035 & 0.309 & 1 & 0.199 & -0.322 & 0.117 & -0.375 & 0.205 & 0.386 & 0.070 & -0.172 & -0.376 & 0.009 & 0.024 \\
\hline (4)Turnover & 0.075 & 0.092 & 0.152 & 1 & 0.209 & 0.475 & 0.028 & 0.248 & 0.331 & 0.032 & 0.198 & 0.151 & 0.060 & $0.005^{\prime}$ \\
\hline (5)Volatility & -0.049 & -0.177 & -0.450 & 0.181 & 1 & -0.195 & 0.454 & -0.223 & -0.211 & -0.032 & 0.149 & 0.031 & 0.045 & -0.205 \\
\hline (6)TradingDay & 0.107 & 0.195 & 0.240 & 0.148 & -0.169 & 1 & -0.132 & 0.447 & 0.415 & 0.091 & 0.255 & 0.201 & -0.076 & -0.068 \\
\hline (7)Loss & -0.032 & -0.162 & -0.389 & 0.089 & 0.500 & -0.105 & 1 & -0.194 & -0.213 & -0.023 & 0.143 & 0.121 & -0.019 & -0.093 \\
\hline (8)AnalystCover & 0.206 & 0.204 & 0.228 & 0.033 & -0.249 & 0.258 & -0.194 & 1 & 0.434 & 0.078 & 0.095 & 0.058 & -0.107 & -0.051 \\
\hline (9)IndexStock & 0.149 & 0.265 & 0.399 & 0.101 & -0.235 & 0.265 & -0.213 & 0.434 & 1 & 0.113 & 0.041 & $-0.001^{\wedge}$ & $-0.005^{\wedge}$ & -0.059 \\
\hline (10)ADR & 0.047 & 0.049 & 0.076 & -0.007 & -0.035 & 0.036 & -0.023 & 0.078 & 0.113 & 1 & -0.047 & -0.022 & 0.012 & 0.038 \\
\hline (11)GDP & 0.227 & -0.030 & -0.149 & 0.041 & 0.225 & 0.024 & 0.128 & 0.085 & 0.043 & -0.043 & 1 & 0.434 & -0.426 & -0.714 \\
\hline (12)MktCap GDP & 0.181 & -0.025 & -0.340 & $0.007^{\wedge}$ & 0.117 & 0.039 & 0.109 & 0.061 & $0.007^{\wedge}$ & -0.020 & 0.310 & 1 & 0.085 & -0.076 \\
\hline (13)GDPGrowth & -0.177 & 0.015 & 0.076 & 0.053 & -0.027 & 0.027 & -0.045 & -0.134 & 0.029 & $-0.002^{\wedge}$ & -0.447 & 0.018 & 1 & 0.416 \\
\hline (14)Trade & -0.135 & 0.013 & -0.077 & -0.017 & -0.167 & -0.010 & -0.051 & -0.064 & -0.085 & 0.010 & -0.766 & 0.042 & 0.408 & 1 \\
\hline
\end{tabular}


TABLE 4 Multivariate analysis of mandatory adopters and non-adopters

This table presents a multivariate analysis of financial integration measures between mandatory adopters and nonadopters of IFRS. This table reports sample distribution by country. Mandatory adopters are firms that switched from local GAAP to IFRS in 2005 or 2006 and are located in countries that mandated IFRS adoption in 2005. Non-adopters are firms that followed local GAAP from 2003 to 2007 and are located in countries that did not mandate IFRS in our sample period. Refer to the Appendix for the definitions of all variables. Reported in parentheses are the $p$-values based on two-tailed tests and firm-cluster adjusted standard errors. ${ }^{* * *},{ }^{* *}$, and * indicate significance at the $1 \%, 5 \%$, and $10 \%$ level, respectively.

\begin{tabular}{|c|c|c|c|c|c|c|}
\hline & \multicolumn{3}{|c|}{ DEP $=$ INTEGRATE } & \multicolumn{3}{|c|}{ DEP $=S P E E D$} \\
\hline & (1) & (2) & (3) & (4) & (5) & (6) \\
\hline Mandatory & $\begin{array}{c}0.050 * * * \\
(0.000)\end{array}$ & & $\begin{array}{c}0.111^{* * *} \\
(0.000)\end{array}$ & $\begin{array}{c}-0.033 * * * \\
(0.000)\end{array}$ & & $\begin{array}{c}-0.014 * * * \\
(0.000)\end{array}$ \\
\hline Post & $\begin{array}{c}0.015 * * * \\
(0.000)\end{array}$ & $\begin{array}{c}-0.023^{* * * *} \\
(0.000)\end{array}$ & $\begin{array}{c}-0.020 * * * \\
(0.000)\end{array}$ & $\begin{array}{c}0.015 * * * \\
(0.000)\end{array}$ & $\begin{array}{c}0.029^{* * * *} \\
(0.000)\end{array}$ & $\begin{array}{c}-0.005 * * * \\
(0.003)\end{array}$ \\
\hline Mandatory $\times$ Post & $\begin{array}{c}0.047 * * * \\
(0.000)\end{array}$ & $\begin{array}{c}0.032 * * * \\
(0.000)\end{array}$ & $\begin{array}{c}0.031^{* * * *} \\
(0.000)\end{array}$ & $\begin{array}{c}0.023 * * * \\
(0.000)\end{array}$ & $\begin{array}{c}0.017 * * * \\
(0.000)\end{array}$ & $\begin{array}{c}0.016 * * * \\
(0.000)\end{array}$ \\
\hline Firm-level controls & & & & & & \\
\hline Size & & $\begin{array}{c}0.016 * * * \\
(0.000)\end{array}$ & $\begin{array}{c}0.001^{* *} \\
(0.033)\end{array}$ & & $\begin{array}{c}0.021^{* * * *} \\
(0.000)\end{array}$ & $\begin{array}{c}0.013 * * * \\
(0.000)\end{array}$ \\
\hline Turnover & & $\begin{array}{c}0.263 * * * \\
(0.000)\end{array}$ & $\begin{array}{c}0.494 * * * \\
(0.000)\end{array}$ & & $\begin{array}{c}0.269 * * * \\
(0.000)\end{array}$ & $\begin{array}{c}0.189 * * * \\
(0.000)\end{array}$ \\
\hline Volatility & & $\begin{array}{c}-0.288^{* * *} \\
(0.000)\end{array}$ & $\begin{array}{c}-0.252 * * * \\
(0.000)\end{array}$ & & $\begin{array}{c}0.077 * * \\
(0.021)\end{array}$ & $\begin{array}{l}-0.058^{*} \\
(0.074)\end{array}$ \\
\hline TradingDay & & $\begin{array}{c}0.009 * * * \\
(0.000)\end{array}$ & $\begin{array}{c}0.015 * * * \\
(0.000)\end{array}$ & & $\begin{array}{c}0.029 * * * \\
(0.000)\end{array}$ & $\begin{array}{c}0.034 * * * \\
(0.000)\end{array}$ \\
\hline Loss & & $\begin{array}{c}-0.011 * * * * \\
(0.000)\end{array}$ & $\begin{array}{c}-0.011 * * * \\
(0.000)\end{array}$ & & $\begin{array}{c}-0.009 * * * \\
(0.000)\end{array}$ & $\begin{array}{c}-0.013 * * * \\
(0.000)\end{array}$ \\
\hline AnalystCover & & $\begin{array}{c}0.011 \text { *** } \\
(0.000)\end{array}$ & $\begin{array}{c}0.038^{* * * *} \\
(0.000)\end{array}$ & & $\begin{array}{c}0.016 * * * \\
(0.000)\end{array}$ & $\begin{array}{c}0.025^{* * * *} \\
(0.000)\end{array}$ \\
\hline IndexStock & & $\begin{array}{c}0.013 * * * \\
(0.000)\end{array}$ & $\begin{array}{c}0.033 * * * \\
(0.000)\end{array}$ & & $\begin{array}{c}0.028 * * * \\
(0.000)\end{array}$ & $\begin{array}{c}0.041^{* * * *} \\
(0.000)\end{array}$ \\
\hline$A D R$ & & $\begin{array}{l}-0.006 \\
(0.474)\end{array}$ & $\begin{array}{c}0.052^{* * * *} \\
(0.000)\end{array}$ & & $\begin{array}{c}0.001 \\
(0.841)\end{array}$ & $\begin{array}{c}0.014 * * \\
(0.027)\end{array}$ \\
\hline Country-level controls & & & & & & \\
\hline$G D P$ & & $\begin{array}{c}0.062 * * * \\
(0.000)\end{array}$ & $\begin{array}{c}0.050 * * * \\
(0.000)\end{array}$ & & $\begin{array}{c}-0.090^{* * * *} \\
(0.000)\end{array}$ & $\begin{array}{c}0.002 \\
(0.230)\end{array}$ \\
\hline MktCap_GDP & & $\begin{array}{c}0.032 * * * \\
(0.001)\end{array}$ & $\begin{array}{c}0.076^{* * * *} \\
(0.000)\end{array}$ & & $\begin{array}{c}-0.032 * * * * \\
(0.000)\end{array}$ & $\begin{array}{c}0.019 * * * \\
(0.000)\end{array}$ \\
\hline GDPGrowth & & $\begin{array}{c}-0.005^{* * * *} \\
(0.005)\end{array}$ & $\begin{array}{c}-0.005^{* * *} \\
(0.000)\end{array}$ & & $\begin{array}{c}0.010 * * * \\
(0.000)\end{array}$ & $\begin{array}{c}-0.002 * * * \\
(0.000)\end{array}$ \\
\hline Trade & & $\begin{array}{c}0.099 * * * \\
(0.006)\end{array}$ & $\begin{array}{c}0.037 * * * \\
(0.000)\end{array}$ & & $\begin{array}{c}-0.080^{* * * *} \\
(0.009)\end{array}$ & $\begin{array}{c}0.028 * * * \\
(0.000)\end{array}$ \\
\hline Industry Fixed Effects & YES & YES & YES & YES & YES & YES \\
\hline Country Fixed Effects & $\mathrm{NO}$ & YES & $\mathrm{NO}$ & $\mathrm{NO}$ & YES & $\mathrm{NO}$ \\
\hline $\mathrm{N}$ & 51,428 & 51,428 & 51,428 & 51,428 & 51,428 & 51,428 \\
\hline Adjusted $\mathrm{R}^{2}$ & 0.0249 & 0.2195 & 0.1601 & 0.0137 & 0.1627 & 0.1426 \\
\hline
\end{tabular}




\section{TABLE 5 Effect of GAAP differences}

This table presents the analysis of the effect of institutional factors on the changes in financial integration measures for mandatory adopters of IFRS. This table reports sample distribution by country. Mandatory adopters are firms that switched from local GAAP to IFRS in 2005 or 2006 and are located in countries that mandated IFRS adoption in 2005. We partition the sample into two groups based on the number of major differences between local GAAP and IFRS, as compiled by Bae et al. (2008). The Large (Small) group includes mandatory adopters located in countries with larger (smaller) GAAP differences than the median of the sample. Refer to the Appendix for the definitions of all variables. Reported in parentheses are the $p$-values based on two-tailed tests and firm-cluster adjusted standard errors. $* * *, * *$, and $*$ indicate significance at the $1 \%, 5 \%$ and $10 \%$ levels, respectively.

\begin{tabular}{|c|c|c|c|c|}
\hline & \multicolumn{2}{|c|}{ DEP = INTEGRATE } & \multicolumn{2}{|c|}{ DEP = SPEED } \\
\hline & $\begin{array}{l}\text { Large } \\
(1)\end{array}$ & $\begin{array}{l}\text { Small } \\
(2)\end{array}$ & $\begin{array}{c}\text { Large } \\
(3)\end{array}$ & $\begin{array}{c}\text { Small } \\
(4)\end{array}$ \\
\hline Post $\left(\beta_{1}\right)$ & $\begin{array}{c}0.040 * * * \\
(0.000)\end{array}$ & $\begin{array}{c}0.001 \\
(0.884)\end{array}$ & $\begin{array}{c}0.025^{* * * *} \\
(0.002)\end{array}$ & $\begin{array}{c}0.011 \\
(0.149)\end{array}$ \\
\hline \multicolumn{5}{|l|}{ Firm-level controls } \\
\hline Size & $\begin{array}{c}0.014 * * * \\
(0.000)\end{array}$ & $\begin{array}{c}0.017 * * * \\
(0.000)\end{array}$ & $\begin{array}{c}0.025^{* * *} * \\
(0.000)\end{array}$ & $\begin{array}{c}0.032 * * * \\
(0.000)\end{array}$ \\
\hline Turnover & $\begin{array}{c}1.668 * * * \\
(0.000)\end{array}$ & $\begin{array}{c}0.607 * * \\
(0.011)\end{array}$ & $\begin{array}{c}0.953 * * * \\
(0.002)\end{array}$ & $\begin{array}{c}0.210 \\
(0.534)\end{array}$ \\
\hline Volatility & $\begin{array}{c}0.372 * \\
(0.065)\end{array}$ & $\begin{array}{c}0.069 \\
(0.746)\end{array}$ & $\begin{array}{c}0.761 * * * \\
(0.000)\end{array}$ & $\begin{array}{c}0.385^{* *} \\
(0.044)\end{array}$ \\
\hline TradingDay & $\begin{array}{c}0.021 * * * \\
(0.007)\end{array}$ & $\begin{array}{c}0.037 * * * \\
(0.000)\end{array}$ & $\begin{array}{c}0.007 \\
(0.366)\end{array}$ & $\begin{array}{c}0.057 * * * \\
(0.000)\end{array}$ \\
\hline Loss & $\begin{array}{l}-0.020^{*} \\
(0.057)\end{array}$ & $\begin{array}{c}0.006 \\
(0.521)\end{array}$ & $\begin{array}{l}-0.011 \\
(0.231)\end{array}$ & $\begin{array}{c}0.005 \\
(0.576)\end{array}$ \\
\hline AnalystCover & $\begin{array}{c}0.033 * * * \\
(0.000)\end{array}$ & $\begin{array}{c}-0.017 * * \\
(0.014)\end{array}$ & $\begin{array}{c}0.031 * * * \\
(0.000)\end{array}$ & $\begin{array}{l}-0.009 \\
(0.159)\end{array}$ \\
\hline IndexStock & $\begin{array}{c}0.036 * * * \\
(0.000)\end{array}$ & $\begin{array}{c}0.013 \\
(0.101)\end{array}$ & $\begin{array}{c}0.021 * * * \\
(0.010)\end{array}$ & $\begin{array}{l}-0.001 \\
(0.904)\end{array}$ \\
\hline$A D R$ & $\begin{array}{l}-0.000 \\
(0.992)\end{array}$ & $\begin{array}{c}-0.034 * * \\
(0.041)\end{array}$ & $\begin{array}{c}0.020 \\
(0.135)\end{array}$ & $\begin{array}{l}-0.005 \\
(0.675)\end{array}$ \\
\hline \multicolumn{5}{|l|}{ Country-level controls } \\
\hline$G D P$ & $\begin{array}{c}0.026^{* * *} * \\
(0.000)\end{array}$ & $\begin{array}{c}0.061 * * * \\
(0.000)\end{array}$ & $\begin{array}{c}-0.015^{* * *} \\
(0.001)\end{array}$ & $\begin{array}{c}0.021 * * * \\
(0.000)\end{array}$ \\
\hline$M k t C a p \_G D P$ & $\begin{array}{c}0.087 * * * \\
(0.000)\end{array}$ & $\begin{array}{l}0.017 * \\
(0.092)\end{array}$ & $\begin{array}{c}-0.057 * * * \\
(0.000)\end{array}$ & $\begin{array}{l}-0.010 \\
(0.226)\end{array}$ \\
\hline GDPGrowth & $\begin{array}{c}-0.020 * * * \\
(0.000)\end{array}$ & $\begin{array}{l}-0.004 \\
(0.277)\end{array}$ & $\begin{array}{c}0.009 * * * \\
(0.001)\end{array}$ & $\begin{array}{c}0.000 \\
(0.948)\end{array}$ \\
\hline Trade & $\begin{array}{c}0.057 * * * \\
(0.000)\end{array}$ & $\begin{array}{c}0.151^{* * * *} \\
(0.000)\end{array}$ & $\begin{array}{c}-0.050 * * * \\
(0.001)\end{array}$ & $\begin{array}{c}0.057 * * * \\
(0.000)\end{array}$ \\
\hline Industry Fixed Effects & YES & YES & YES & YES \\
\hline $\begin{array}{l}\text { Difference in } \beta_{1} \\
\text { ( } p \text {-value })\end{array}$ & \multicolumn{2}{|c|}{$\begin{array}{c}0.039 * * * \\
(0.002)\end{array}$} & \multicolumn{2}{|c|}{$\begin{array}{l}0.014 * \\
(0.087) \\
\end{array}$} \\
\hline $\begin{array}{l}\mathrm{N} \\
\text { Adjusted } \mathrm{R}^{2}\end{array}$ & $\begin{array}{c}4,744 \\
0.1169\end{array}$ & $\begin{array}{c}4,284 \\
0.1303\end{array}$ & $\begin{array}{c}4,284 \\
0.1532\end{array}$ & $\begin{array}{c}4,744 \\
0.1611\end{array}$ \\
\hline
\end{tabular}


TABLE 6 Cross-sectional analysis - Accounting comparability

This table presents analysis of cross-sectional differences in the changes in financial integration measures for mandatory adopters of IFRS. This table reports sample distribution by country. Mandatory adopters are firms that switched from local GAAP to IFRS in 2005 or 2006 and are located in countries that mandated IFRS adoption in 2005. We partition the sample based on the firm's change in accounting comparability from pre- to post-IFRS period. Large (Small) group includes firms with changes in accounting comparability above (below) the third quartile in the sample. Refer to the Appendix for the definitions of all variables. Reported in parentheses are the $p$-values based on two-tailed tests and firm-cluster adjusted standard errors. ***, **, and * indicate significance at the $1 \%, 5 \%$ and $10 \%$ level, respectively.

\begin{tabular}{|c|c|c|c|c|}
\hline & \multicolumn{2}{|c|}{$\mathrm{DEP}=$ INTEGRATE } & \multicolumn{2}{|c|}{ DEP $=$ SPEED } \\
\hline & $\begin{array}{l}\text { Large } \\
(1)\end{array}$ & $\begin{array}{c}\text { Small } \\
(2)\end{array}$ & $\begin{array}{l}\text { Large } \\
(3)\end{array}$ & $\begin{array}{c}\text { Small } \\
(4)\end{array}$ \\
\hline Post $\left(\beta_{1}\right)$ & $\begin{array}{c}0.044 * * * \\
(0.001)\end{array}$ & $\begin{array}{c}0.026 * * * \\
(0.002)\end{array}$ & $\begin{array}{c}0.029 * * \\
(0.016)\end{array}$ & $\begin{array}{c}0.006 \\
(0.382)\end{array}$ \\
\hline Size & $\begin{array}{c}0.017 * * * \\
(0.003)\end{array}$ & $\begin{array}{c}0.016 * * * \\
(0.000)\end{array}$ & $\begin{array}{c}0.029 * * * \\
(0.000)\end{array}$ & $\begin{array}{c}0.034 * * * \\
(0.000)\end{array}$ \\
\hline Turnover & $\begin{array}{c}0.532 \\
(0.326)\end{array}$ & $\begin{array}{c}1.272 * * * \\
(0.001)\end{array}$ & $\begin{array}{c}0.508 \\
(0.305)\end{array}$ & $\begin{array}{l}0.687 * * \\
(0.042)\end{array}$ \\
\hline Volatility & $\begin{array}{c}0.470 \\
(0.276)\end{array}$ & $\begin{array}{c}0.089 \\
(0.718)\end{array}$ & $\begin{array}{c}0.408 \\
(0.275)\end{array}$ & $\begin{array}{l}0.588 * * \\
(0.010)\end{array}$ \\
\hline TradingDay & $\begin{array}{c}0.013 \\
(0.303)\end{array}$ & $\begin{array}{c}0.029 * * * \\
(0.002)\end{array}$ & $\begin{array}{c}0.012 \\
(0.510)\end{array}$ & $\begin{array}{l}0.023 * * \\
(0.017)\end{array}$ \\
\hline Loss & $\begin{array}{l}-0.012 \\
(0.530)\end{array}$ & $\begin{array}{l}-0.017 \\
(0.170)\end{array}$ & $\begin{array}{c}0.023 \\
(0.148)\end{array}$ & $\begin{array}{l}-0.003 \\
(0.803)\end{array}$ \\
\hline AnalystCover & $\begin{array}{l}0.024 * \\
(0.088)\end{array}$ & $\begin{array}{c}0.010 \\
(0.266)\end{array}$ & $\begin{array}{l}0.025^{*} \\
(0.064)\end{array}$ & $\begin{array}{c}0.004 \\
(0.579)\end{array}$ \\
\hline IndexStock & $\begin{array}{l}0.041 * * \\
(0.013)\end{array}$ & $\begin{array}{c}0.006 \\
(0.552)\end{array}$ & $\begin{array}{c}0.007 \\
(0.677)\end{array}$ & $\begin{array}{l}-0.013 \\
(0.191)\end{array}$ \\
\hline$A D R$ & $\begin{array}{l}-0.069 \\
(0.102)\end{array}$ & $\begin{array}{l}-0.001 \\
(0.963)\end{array}$ & $\begin{array}{c}0.003 \\
(0.925)\end{array}$ & $\begin{array}{l}-0.006 \\
(0.678)\end{array}$ \\
\hline Industry Fixed Effects & YES & YES & YES & YES \\
\hline Country Fixed Effects & YES & YES & YES & YES \\
\hline $\begin{array}{l}\text { Difference in } \beta_{1} \\
\text { ( } p \text {-value) }\end{array}$ & \multicolumn{2}{|c|}{$\begin{array}{l}0.018^{*} \\
(0.076)\end{array}$} & \multicolumn{2}{|c|}{$\begin{array}{l}0.023^{*} \\
(0.053) \\
\end{array}$} \\
\hline $\begin{array}{l}\mathrm{N} \\
\text { Adjusted } \mathrm{R}^{2}\end{array}$ & $\begin{array}{c}1,116 \\
0.1052 \\
\end{array}$ & $\begin{array}{c}3,272 \\
0.1107 \\
\end{array}$ & $\begin{array}{c}1,116 \\
0.1226 \\
\end{array}$ & $\begin{array}{c}3,272 \\
0.1485 \\
\end{array}$ \\
\hline
\end{tabular}


TABLE 7 Cross-sectional analysis - Increases in foreign institutional ownership

This table presents analysis of cross-sectional difference in the changes in financial integration measures for mandatory adopters of IFRS. This table reports sample distribution by country. Mandatory adopters are firms that switched from local GAAP to IFRS in 2005 or 2006 and are located in countries that mandated IFRS adoption in 2005. We partition the sample based on the firm's change in the mean foreign ownership from pre- to post-IFRS period. Large (Small) group includes firms with changes in foreign ownership above (below) the third quartile of the sample. Refer to the Appendix for the definitions of all variables. Reported in parentheses are the $p$-values based on two-tailed tests and firm-cluster adjusted standard errors. ***, **, and * indicate significance at the $1 \%$, $5 \%$ and $10 \%$ level, respectively.

\begin{tabular}{|c|c|c|c|c|}
\hline & \multicolumn{2}{|c|}{$\mathrm{DEP}=I N T E G R A T E$} & \multicolumn{2}{|c|}{$\mathrm{DEP}=S P E E D$} \\
\hline & $\begin{array}{c}\text { Large } \\
(1)\end{array}$ & $\begin{array}{c}\text { Small } \\
(2)\end{array}$ & $\begin{array}{c}\text { Large } \\
(3)\end{array}$ & $\begin{array}{c}\text { Small } \\
(4)\end{array}$ \\
\hline $\operatorname{Post}\left(\beta_{1}\right)$ & $\begin{array}{c}0.080 * * * \\
(0.003)\end{array}$ & $\begin{array}{c}0.045 * * * \\
(0.006)\end{array}$ & $\begin{array}{c}0.047 * * \\
(0.018)\end{array}$ & $\begin{array}{c}0.012 \\
(0.272)\end{array}$ \\
\hline Size & $\begin{array}{c}0.009 \\
(0.345)\end{array}$ & $\begin{array}{c}0.007 \\
(0.265)\end{array}$ & $\begin{array}{c}0.035 * * * \\
(0.000)\end{array}$ & $\begin{array}{c}0.037 * * * \\
(0.000)\end{array}$ \\
\hline Turnover & $\begin{array}{c}1.214 \\
(0.129)\end{array}$ & $\begin{array}{c}0.358 \\
(0.539)\end{array}$ & $\begin{array}{l}-0.281 \\
(0.580)\end{array}$ & $\begin{array}{c}0.330 \\
(0.488)\end{array}$ \\
\hline Volatility & $\begin{array}{c}0.544 \\
(0.539)\end{array}$ & $\begin{array}{l}1.046 * * \\
(0.029)\end{array}$ & $\begin{array}{c}0.986 \\
(0.195)\end{array}$ & $\begin{array}{c}1.031 * * * \\
(0.000)\end{array}$ \\
\hline TradingDay & $\begin{array}{c}0.019 \\
(0.495)\end{array}$ & $\begin{array}{l}0.082 * \\
(0.076)\end{array}$ & $\begin{array}{c}0.021 \\
(0.367)\end{array}$ & $\begin{array}{c}0.082 * * \\
(0.022)\end{array}$ \\
\hline Loss & $\begin{array}{l}-0.056 \\
(0.397)\end{array}$ & $\begin{array}{l}-0.001 \\
(0.971)\end{array}$ & $\begin{array}{l}-0.001 \\
(0.987)\end{array}$ & $\begin{array}{l}-0.014 \\
(0.551)\end{array}$ \\
\hline AnalystCover & $\begin{array}{c}0.010 \\
(0.678)\end{array}$ & $\begin{array}{c}0.001 \\
(0.923)\end{array}$ & $\begin{array}{c}0.019 \\
(0.285)\end{array}$ & $\begin{array}{c}0.014 \\
(0.244)\end{array}$ \\
\hline IndexStock & $\begin{array}{l}-0.096 * \\
(0.072)\end{array}$ & $\begin{array}{c}0.063 * * \\
(0.034)\end{array}$ & $\begin{array}{l}-0.005 \\
(0.902)\end{array}$ & $\begin{array}{l}0.060 * * \\
(0.030)\end{array}$ \\
\hline$A D R$ & $\begin{array}{l}-0.015 \\
(0.709)\end{array}$ & $\begin{array}{c}-0.036 * * \\
(0.024)\end{array}$ & $\begin{array}{l}-0.014 \\
(0.534)\end{array}$ & $\begin{array}{c}-0.032 * * \\
(0.015)\end{array}$ \\
\hline Industry Fixed Effects & YES & YES & YES & YES \\
\hline Country Fixed Effects & YES & YES & YES & YES \\
\hline $\begin{array}{l}\text { Difference in } \beta_{1} \\
(p \text {-value })\end{array}$ & \multicolumn{2}{|c|}{$\begin{array}{c}0.035^{* *} \\
(0.038) \\
\end{array}$} & \multicolumn{2}{|c|}{$\begin{array}{c}0.035^{* *} \\
(0.041) \\
\end{array}$} \\
\hline $\begin{array}{l}\mathrm{N} \\
\text { Adjusted } \mathrm{R}^{2}\end{array}$ & $\begin{array}{c}398 \\
0.1206\end{array}$ & $\begin{array}{c}1,171 \\
0.2005\end{array}$ & $\begin{array}{c}398 \\
0.1354\end{array}$ & $\begin{array}{c}1,171 \\
0.1748\end{array}$ \\
\hline
\end{tabular}




\section{University Library}

\section{- M M I N E R VA A gateway to Melbourne's research publications}

Minerva Access is the Institutional Repository of The University of Melbourne

Author/s:

Li, Y;Dhaliwal, D;He, W;Pereira, R

Title:

Accounting Standards Harmonization and Financial Integration

Date:

2019

Citation:

Li, Y., Dhaliwal, D., He, W. \& Pereira, R. (2019). Accounting Standards Harmonization and Financial Integration. Contemporary Accounting Research, 36 (4), pp.2437-2466. https:// doi.org/10.1111/1911-3846.12495.

Persistent Link:

http://hdl.handle.net/11343/286817 